\title{
Potential Impacts of Plug-in Hybrid Electric Vehicles on Regional Power Generation
}

\section{January 2008}

Prepared by

Stanton W. Hadley

Alexandra Tsvetkova 


\title{
DOCUMENT AVAILABILITY
}

Reports produced after January 1, 1996, are generally available free via the U.S. Department of Energy (DOE) Information Bridge:

Web site: http://www.osti.gov/bridge

Reports produced before January 1, 1996, may be purchased by members of the public from the following source:

\author{
National Technical Information Service \\ 5285 Port Royal Road \\ Springfield, VA 22161 \\ Telephone: 703-605-6000 (1-800-553-6847) \\ TDD: 703-487-4639 \\ Fax: 703-605-6900 \\ E-mail: info@ntis.fedworld.gov \\ Web site: http://www.ntis.gov/support/ordernowabout.htm
}

Reports are available to DOE employees, DOE contractors, Energy Technology Data Exchange (ETDE) representatives, and International Nuclear Information System (INIS) representatives from the following source:

Office of Scientific and Technical Information

P.O. Box 62

Oak Ridge, TN 37831

Telephone: 865-576-8401

Fax: 865-576-5728

E-mail: reports@adonis.osti.gov

Web site: http://www.osti.gov/contact.html

\begin{abstract}
This report was prepared as an account of work sponsored by an agency of the United States Government. Neither the United States government nor any agency thereof, nor any of their employees, makes any warranty, express or implied, or assumes any legal liability or responsibility for the accuracy, completeness, or usefulness of any information, apparatus, product, or process disclosed, or represents that its use would not infringe privately owned rights. Reference herein to any specific commercial product, process, or service by trade name, trademark, manufacturer, or otherwise, does not necessarily constitute or imply its endorsement, recommendation, or favoring by the United States Government or any agency thereof. The views and opinions of authors expressed herein do not necessarily state or reflect those of the United States Government or any agency thereof.
\end{abstract}




\title{
Potential Impacts of Plug-in Hybrid Electric Vehicles on Regional Power Generation
}

\author{
Stanton W. Hadley
}

Alexandra Tsvetkova

January 2008

OAK RIDGE NATIONAL LABORATORY

Oak Ridge, Tennessee 37831

managed by

UT-BATTELLE, LLC

for the

U.S. DEPARTMENT OF ENERGY

under contract No. DE-AC05-00OR22725 


\section{CONTENTS}

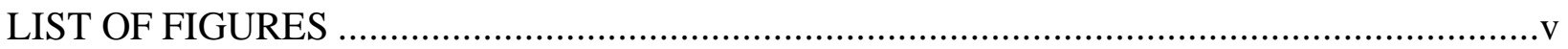

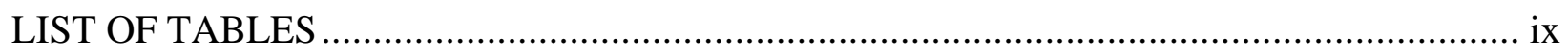

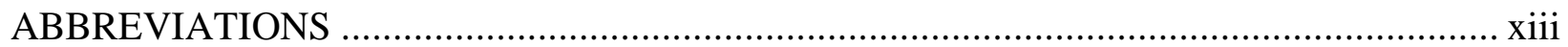

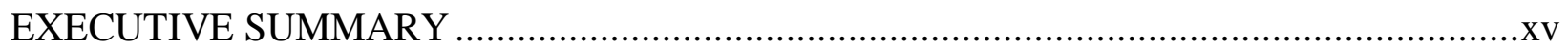

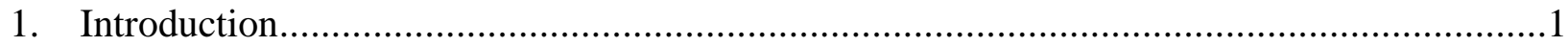

2. PHEV Characteristics and Market .....................................................................

2.1 Number of Vehicles ................................................................................. 5

2.2 Charging Characteristics ...................................................................... 7

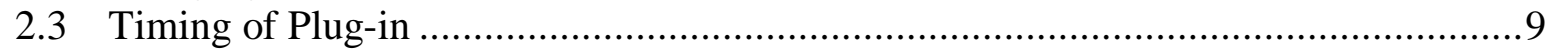

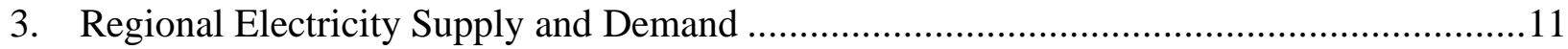

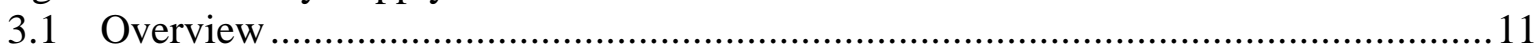

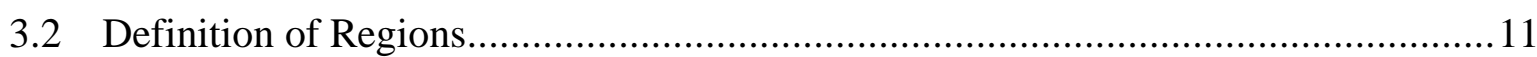

3.3 Demand Estimation................................................................................. 12

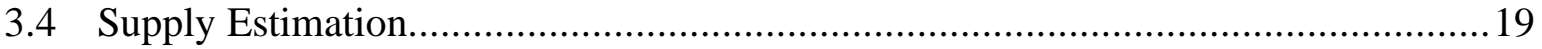

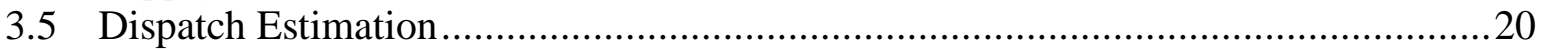

4. Regional Analysis ..........................................................................................23

4.1 East Central Area Reliability Coordination Agreement (ECAR).............................25

4.2 Electric Reliability Council of Texas (ERCOT) ...........................................28

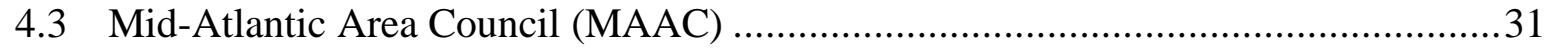

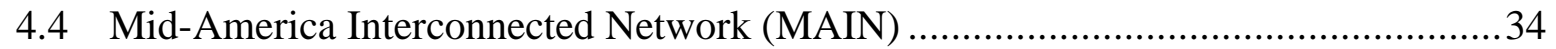

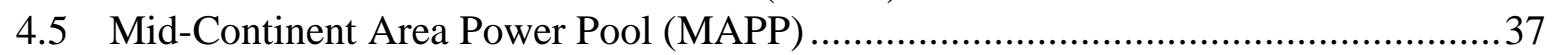

4.6 Northeast Power Coordinating Council - New York (NPCC - NY) ......................40

4.7 Northeast Power Coordinating Council - New England (NPCC -NE) ....................43

4.8 Florida Reliability Coordinating Council (FRCC) ...........................................46

4.9 Southeastern Electric Reliability Council (SERC) ............................................49

4.10 Southwest Power Pool (SPP) .....................................................................52

4.11 Western Electricity Coordinating Council - Northwest Power Pool Area (WECC -

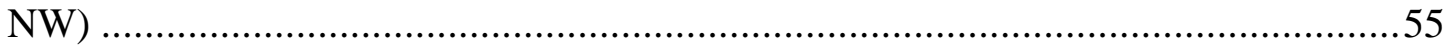

4.12 Western Electricity Coordinating Council - Rocky Mountain Power Area and Arizona-New Mexico-Southern Nevada Power Area (WECC - RMP/ANM) ...........58

4.13 Western Electricity Coordinating Council - California (WECC - CA) ....................61

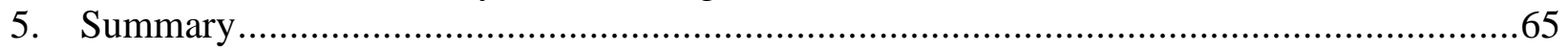

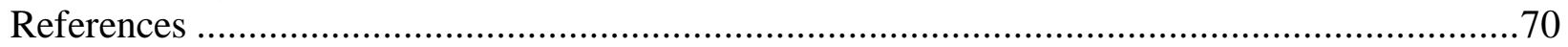





\section{LIST OF FIGURES}

Figure 1. Past and projected vehicle sales in the United States...................................................5

Figure 2. Projected market share of PHEVs......................................................................6

Figure 3. Projected number of PHEVs sold per year..........................................................6

Figure 4. Hourly demand for a PHEV20vehicles at varying voltages and currents......................8

Figure 5. Weighted average charging profile for all vehicles with half charging one hour later..10

Figure 6. Regions as specified in Annual Energy Outlook 2007...............................................11

Figure 7. Hourly loads for ECAR in 2030 based on escalated 2005 loads.................................12

Figure 8. Added demand from PHEV charging scenarios on the peak day in ECAR for 2020....14

Figure 9. Added demand from the $2 \mathrm{~kW}$ PHEV charging scenarios on the peak weeks in summer (top), winter (middle), and off-peak (bottom) seasons in ECAR for 2030..........................16

Figure 10. Load duration curve for ECAR in 2020 with no PHEVs........................................17

Figure 11. Summer LDC for the ECAR region in 2030 showing no PHEVs and with charging at

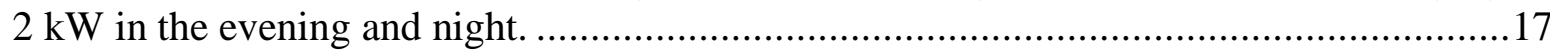

Figure 12. Addition of PHEV night charging to ECAR 2020 summer season LDC....................18

Figure 13. Addition of PHEV evening charging to ECAR 2020 summer season LDC. ...............18

Figure 14. Projected 2020 generating capacity (left), base generation (center), and new generation dispatched to meet demand for each PHEV recharging scenario (right) for ECAR.

Figure 15. Projected 2030 generating capacity (left), base generation (center), and new generation dispatched to meet demand for each PHEV recharging scenario (right) for ECAR.

Figure 16. Projected 2020 generating capacity (left), base generation (center), and new generation dispatched to meet demand for each PHEV recharging scenario (right) for ERCOT.

Figure 17. Projected 2030 generating capacity (left), base generation (center), and new generation dispatched to meet demand for each PHEV recharging scenario (right) for ERCOT.

Figure 18. Projected 2020 generating capacity (left), base generation (center), and new generation dispatched to meet demand for each PHEV recharging scenario (right) for MAAC

Figure 19. Projected 2030 generating capacity (left), base generation (center), and new generation dispatched to meet demand for each PHEV recharging scenario (right) for MAAC.

Figure 20. Projected 2020 generating capacity (left), base generation (center), and new 
generation dispatched to meet demand for each PHEV recharging scenario (right) for MAIN.

Figure 21. Projected 2030 generating capacity (left), base generation (center), and new generation dispatched to meet demand for each PHEV recharging scenario (right) for MAIN

Figure 22. Projected 2020 generating capacity (left), base generation (center), and new generation dispatched to meet demand for each PHEV recharging scenario (right) for MAPP.

Figure 23. Projected 2030 generating capacity (left), base generation (center), and new generation dispatched to meet demand for each PHEV recharging scenario (right) for MAPP.

Figure 24. Projected 2020 generating capacity (left), base generation (center), and new generation dispatched to meet demand for each PHEV recharging scenario (right) for NPCC-NY.

Figure 25. Projected 2030 generating capacity (left), base generation (center), and new generation dispatched to meet demand for each PHEV recharging scenario (right) for NPCC-NY.

Figure 26. Projected 2020 generating capacity (left), base generation (center), and new generation dispatched to meet demand for each PHEV recharging scenario (right) for NPCC-NE.

Figure 27. Projected 2030 generating capacity (left), base generation (center), and new generation dispatched to meet demand for each PHEV recharging scenario (right) for NPCC-NE.

Figure 28. Projected 2020 generating capacity (left), base generation (center), and new generation dispatched to meet demand for each PHEV recharging scenario (right) for FRCC.

Figure 29. Projected 2030 generating capacity (left), base generation (center), and new generation dispatched to meet demand for each PHEV recharging scenario (right) for FRCC.

Figure 30. Projected 2020 generating capacity (left), base generation (center), and new generation dispatched to meet demand for each PHEV recharging scenario (right) for SERC.

Figure 31. Projected 2030 generating capacity (left), base generation (center), and new generation dispatched to meet demand for each PHEV recharging scenario (right) for SERC.

Figure 32. Projected 2020 generating capacity (left), base generation (center), and new generation dispatched to meet demand for each PHEV recharging scenario (right) for SPP.

Figure 33. Projected 2030 generating capacity (left), base generation (center), and new generation dispatched to meet demand for each PHEV recharging scenario (right) for SPP. 
Figure 34. Projected 2020 generating capacity (left), base generation (center), and new generation dispatched to meet demand for each PHEV recharging scenario (right) for WECC-NWP.

Figure 35. Projected 2030 generating capacity (left), base generation (center), and new generation dispatched to meet demand for each PHEV recharging scenario (right) for WECC-NWP.

Figure 36. Projected 2020 generating capacity (left), base generation (center), and new generation dispatched to meet demand for each PHEV recharging scenario (right) for WECC-RMP.

Figure 37. Projected 2020 generating capacity (left), base generation (center), and new generation dispatched to meet demand for each PHEV recharging scenario (right) for WECC-RMP.

Figure 38. Projected 2020 generating capacity (left), base generation (center), and new generation dispatched to meet demand for each PHEV recharging scenario (right) for WECC-CA.

Figure 39. Projected 2030 generating capacity (left), base generation (center), and new generation dispatched to meet demand for each PHEV recharging scenario (right) for WECC-CA.

Figure 40. Sum for all regions of projected 2020 generating capacity (left), base generation (center), and new generation dispatched to meet demand for each PHEV recharging scenario (right).

Figure 41. Sum for all regions of projected 2030 generating capacity (left), base generation (center), and new generation dispatched to meet demand for each PHEV recharging scenario (right). 



\section{LIST OF TABLES}

Table 1. Each region's share of total vehicles registered in 2004 and projected number of

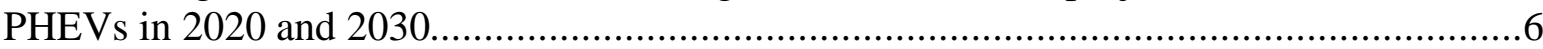

Table 2. Charging times required for PHEV20s for $20-100 \%$ SOC, with $1.2-1.4 \mathrm{~kW}$ power and 1 or 2 hours conditioning (Duvall 2006) ...................................................................

Table 3. Power requirements and $\mathrm{kWh}$ demand by hour for PHEV20s at $120 \mathrm{~V} / 15 \mathrm{~A} \mathrm{.................8}$

Table 4. Increased demand in 2020 in each region from charging PHEVs at $1.4 \mathrm{~kW}(\mathrm{GW})$, for

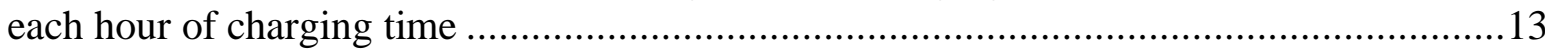

Table 5. Increase in electrical demand due to PHEVs for each region in 2020 and 2030............13

Table 6. Highest demand increase from PHEV charging at each power level in 2020 and 2030,

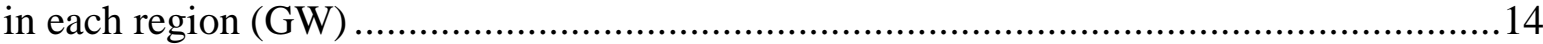

Table 7. Increase in annual peak demand with PHEV charging at $6 \mathrm{~kW}$ in the evening..............18

Table 8. Power plant nameplate capacity by region in $2020(\mathrm{GW})$.........................................19

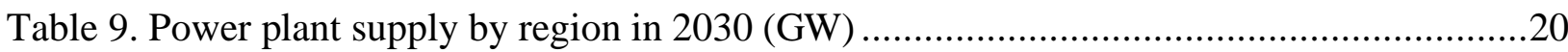

Table 10. Emissions credit prices projected for each region by Annual Energy Outlook 2007

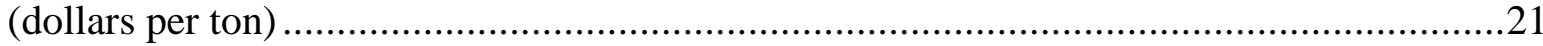

Table 11. Capacity and peak demand in each season under each charging scenario for 2020 and

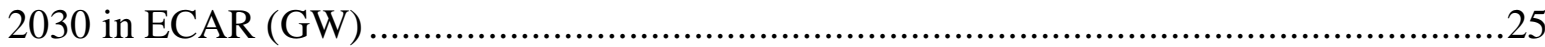

Table 12. Generation, primary energy in, emissions, electricity prices, and PHEV charging costs in 2020 and 2030 for ECAR.

Table 13. Comparison of fuels, emissions, and costs for PHEVs using 2-kW recharging versus gasoline-fueled HEVs in ECAR, 2020 and 2030.......................................................28

Table 14. Capacity and peak demand in each season under each charging scenario for 2020 and

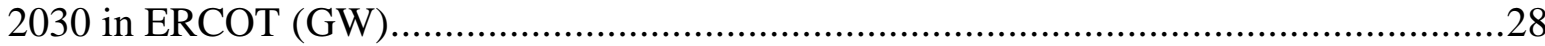

Table 15. Generation, primary energy in, emissions, electricity prices, and PHEV charging costs in 2020 and 2030 for ERCOT.

Table 16. Comparison of fuels, emissions, and costs for PHEVs using 2-kW recharging versus gasoline-fueled HEVs in ERCOT, 2020 and 2030 ........................................................

Table 17. Capacity and peak demand in each season under each charging scenario for 2020 and 2030 in MAAC $(\mathrm{GW})$

Table 18. Generation, primary energy in, emissions, electricity prices, and PHEV charging costs in 2020 and 2030 for MAAC.

Table 19. Comparison of fuels, emissions, and costs for PHEVs using 2-kW recharging versus gasoline-fueled HEVs in MAAC, 2020 and 2030. 
Table 20. Capacity and peak demand in each season under each charging scenario for 2020 and

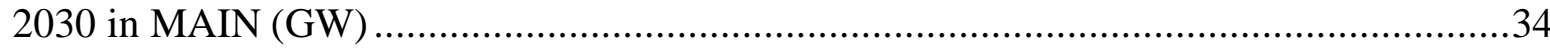

Table 21. Generation, primary energy in, emissions, electricity prices, and PHEV charging costs in 2020 and 2030 for MAIN.

Table 22. Comparison of fuels, emissions, and costs for PHEVs using 2-kW recharging versus gasoline-fueled HEVs in MAIN, 2020 and 2030.

Table 23. Capacity and peak demand in each season under each charging scenario for 2020 and 2030 in MAPP $(\mathrm{GW})$ 37

Table 24. Generation, primary energy in, emissions, electricity prices, and PHEV charging costs in 2020 and 2030 for MAPP.

Table 25. Comparison of fuels, emissions, and costs for PHEVs using 2-kW recharging versus gasoline-fueled HEVs in MAPP, 2020 and 2030.

Table 26. Capacity and peak demand in each season under each charging scenario for 2020 and 2030 in NPCC-NY (GW)

Table 27. Generation, primary energy in, emissions, electricity prices, and PHEV charging costs in 2020 and 2030 for NPCC-NY.

Table 28. Comparison of fuels, emissions, and costs for PHEVs using 2-kW recharging versus gasoline-fueled HEVs in NPCC-NY, 2020 and 2030

Table 29. Capacity and peak demand in each season under each charging scenario for 2020 and 2030 in NPCC-NE $(\mathrm{GW})$.

Table 30. Generation, primary energy in, emissions, electricity prices, and PHEV charging costs in 2020 and 2030 for NPCC-NE.

Table 31. Comparison of fuels, emissions, and costs for PHEVs using 2-kW recharging versus gasoline-fueled HEVs in NPCC-NE, 2020 and 2030.

Table 32. Capacity and peak demand in each season under each charging scenario for 2020 and 2030 in FRCC (GW)

Table 33. Generation, primary energy in, emissions, electricity prices, and PHEV charging costs in 2020 and 2030 for FRCC.

Table 34. Comparison of fuels, emissions, and costs for PHEVs using 2-kW recharging versus gasoline-fueled HEVs in FRCC, 2020 and 2030.

Table 35. Capacity and peak demand in each season under each charging scenario for 2020 and 2030 in SERC (GW).

Table 36. Generation, primary energy in, emissions, electricity prices, and PHEV charging costs in 2020 and 2030 for SERC.

Table 37. Comparison of fuels, emissions, and costs for PHEVs using 2-kW recharging versus gasoline-fueled HEVs in SERC, 2020 and 2030 .....

Table 38. Capacity and peak demand in each season under each scenario for 2020 and 2030 in SPP $(\mathrm{GW})$..... 
Table 39. Generation, primary energy in, emissions, electricity prices, and PHEV charging costs in 2020 and 2030 for SPP.

Table 40. Comparison of fuels, emissions, and costs for PHEVs using 2-kW recharging versus gasoline-fueled HEVs in SPP, 2020 and 2030.

Table 41. Capacity and peak demand in each season under each scenario for 2020 and 2030 in WECC-NW (GW) .55

Table 42. Generation, primary energy in, emissions, electricity prices, and PHEV charging costs in 2020 and 2030 for WECC-NW.

Table 43. Comparison of fuels, emissions, and costs for PHEVs using 2-kW recharging versus gasoline-fueled HEVs in WECC-NWP, 2020 and 2030

Table 44. Capacity and peak demand in each season under each scenario for 2020 and 2030 in

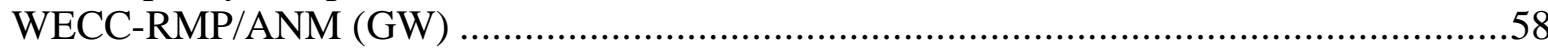

Table 45. Generation, primary energy in, emissions, electricity prices, and PHEV charging costs in 2020 and 2030 for WECC-RMP/ANM.

Table 46. Comparison of fuels, emissions, and costs for PHEVs using 2-kW recharging versus gasoline-fueled HEVs in WECC-RMP/ANM, 2020 and 2030.

Table 47. Capacity and peak demand in each season under each scenario for 2020 and 2030 in WECC-CA (GW) .

Table 48. Generation, primary energy in, emissions, electricity prices, and PHEV charging costs in 2020 and 2030 for WECC-CA.

Table 49. Comparison of fuels, emissions, and costs for PHEVs using 2-kW recharging versus gasoline-fueled HEVs in WECC-CA, 2020 and 2030

Table 50. Generalized description of the types of fuels expected to be used to generate added electricity load for charging PHEVs in each region, 2020 and 2030

Table 51. Generation, primary energy in, emissions, and electricity prices and costs in 2020 and 2030 for all regions.

Table 52. Comparison of fuels, emissions, and costs predicted for PHEVs using $2 \mathrm{~kW}$ recharging versus gasoline-fueled HEVs, sum of all regions, 2020 and 2030. .69 


\section{ABBREVIATIONS}

\begin{tabular}{|c|c|}
\hline DOE & U.S. Department of Energy \\
\hline EIA & Energy Information Administration \\
\hline EPRI & Electric Power Research Institute \\
\hline FERC & Federal Energy Regulatory Commission \\
\hline $\mathrm{HEV}$ & Hybrid electric vehicle \\
\hline $\mathrm{kWH}$ & kilowatt-hours \\
\hline LDC & Load duration curve \\
\hline Li-ion & Lithium-ion \\
\hline MWH & Megawatt-hours (= 1,000 kWH) \\
\hline NEMS & National Energy Modeling System \\
\hline NERC & North American Electric Reliability Corporation \\
\hline ORCED & Oak Ridge Competitive Electricity Dispatch model \\
\hline PEV & Plug-in electric vehicle \\
\hline PHEV & Plug-in hybrid electric vehicle \\
\hline PHEV20 & PHEV that can travel 20 miles on battery power before recharging \\
\hline PHEV40 & PHEV that can travel 40 miles on battery power before recharging \\
\hline PHEV60 & PHEV that can travel 60 miles on battery power before recharging \\
\hline PWH & Petawatt-hours $(=1,000 \mathrm{TWH})$ \\
\hline SOC & State of charge \\
\hline TWH & Terawatt-hours (= 1,000 MWH) \\
\hline
\end{tabular}




\section{REGIONS}

1. ECAR

2. ERCOT

3. MAAC

4. MAIN

5. MAPP

6. $\mathrm{NPCC}-\mathrm{NY}$

7. NPCC $-\mathrm{NE}$

8. FRCC

9. SERC

10. SPP

11. WECC-NW

12. WECC-RMP/ANM

13. WECC-CA
East Central Area Reliability Coordination Agreement

Electric Reliability Council of Texas

Mid-Atlantic Area Council

Mid-America Interconnected Network

Mid-Continent Area Power Pool

Northeast Power Coordinating Council / NY

Northeast Power Coordinating Council / New England

Florida Reliability Coordinating Council;

Southeastern Electric Reliability Council

Southwest Power Pool

Western Electricity Coordinating Council / Northwest Power Pool Area

Western Electricity Coordinating Council / Rocky Mountain Power Area and Arizona-New Mexico-Southern Nevada Power Area

Western Electricity Coordinating Council / California 


\section{EXECUTIVE SUMMARY}

Plug-in hybrid electric vehicles (PHEVs) are being developed around the world, with much work aiming to optimize engine and battery for efficient operation, both during discharge and when grid electricity is available for recharging. However, the general expectation has been that the grid will not be greatly affected by the use of PHEVs because the recharging will occur during off-peak hours, or the number of vehicles will grow slowly enough so that capacity planning will respond adequately. This expectation does not consider that drivers will control the timing of recharging, and their inclination will be to plug in when convenient, rather than when utilities would prefer.

It is important to understand the ramifications of adding load from PHEVs onto the grid. Depending on when and where the vehicles are plugged in, they could cause local or regional constraints on the grid. They could require the addition of new electric capacity and increase the utilization of existing capacity. Usage patterns of local distribution grids will change, and some lines or substations may become overloaded sooner than expected. Furthermore, the type of generation used to meet the demand for recharging PHEVs will depend on the region of the country and the timing of recharging.

This paper analyzes the potential impacts of PHEVs on electricity demand, supply, generation structure, prices, and associated emission levels in 2020 and 2030 in 13 regions specified by the North American Electric Reliability Corporation (NERC) and the U.S. Department of Energy's (DOE's) Energy Information Administration (EIA), and on which the data and analysis in EIA's Annual Energy Outlook 2007 are based (Figure ES-1). The estimates of power plant supplies and regional hourly electricity demand come from publicly available sources from EIA and the Federal Energy Regulatory Commission. Electricity requirements for PHEVs are based on analysis from the Electric Power Research Institute, with an optimistic projection of $25 \%$ market penetration by 2020, involving a mixture of sedans and sport utility vehicles. The calculations were done using the Oak Ridge Competitive Electricity Dispatch (ORCED) model, a model developed over the past 12 years to evaluate a wide variety of critical electricity sector issues.

Seven scenarios were run for each region for 2020 and 2030, for a total of 182 scenarios. In addition to a base scenario of no PHEVs, the authors modeled scenarios assuming that vehicles were either plugged in starting at 5:00 p.m. (evening) or at 10:00 p.m.(night) and left until fully charged. Three charging rates were examined: $120 \mathrm{~V} / 15 \mathrm{~A}(1.4 \mathrm{~kW}), 120 \mathrm{~V} / 20 \mathrm{~A}(2 \mathrm{~kW})$, and $220 \mathrm{~V} / 30 \mathrm{~A}(6 \mathrm{~kW})$.

Most regions will need to build additional capacity or utilize demand response to meet the added demand from PHEVs in the evening charging scenarios, especially by 2030 when PHEVs have a larger share of the installed vehicle base and make a larger demand on the system. The added demands of evening charging, especially at high power levels, can impact the overall demand peaks and reduce the reserve margins for a region's system. Night recharging has little potential to influence peak loads, but will still influence the amount and type of generation. 


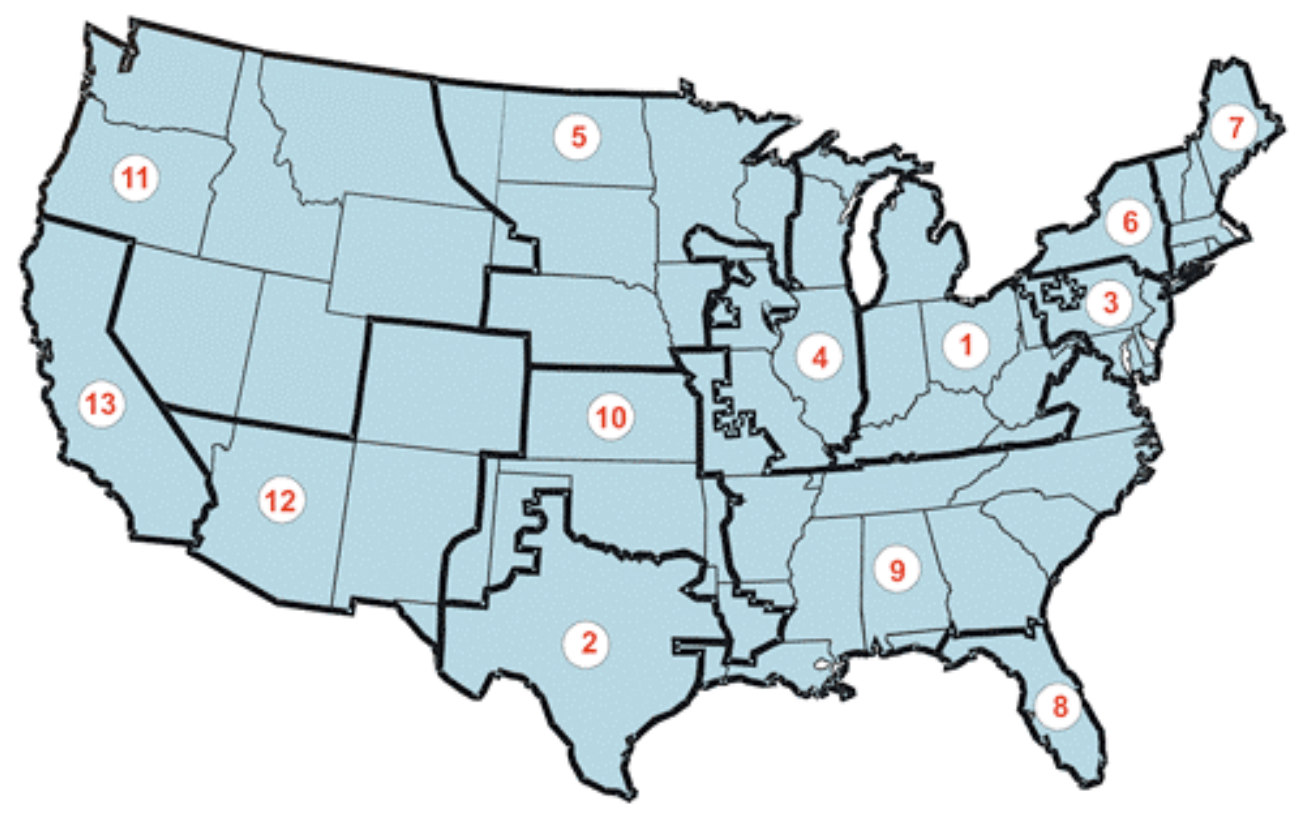

Figure ES-1. Regions as specified by EIA for Annual Energy Outlook 2007:

1. ECAR—East Central Area Reliability Coordination Agreement

2. ERCOT - Electric Reliability Council of Texas

3. MAAC - Mid-Atlantic Area Council

4. MAIN - Mid-America Interconnected Network

5. MAPP - Mid-Continent Area Power Pool

6. NPCC -NY - Northeast Power Coordinating Council / NY

7. NPCC -NE - Northeast Power Coordinating Council / New England

8. FRCC - Florida Reliability Coordinating Council;

9. SERC — Southeastern Electric Reliability Council

10. SPP - Southwest Power Pool

11. WECC-NW - Western Electricity Coordinating Council / Northwest Power Pool Area

12. WECC-RMP/ANM - Western Electricity Coordinating Council / Rocky Mountain

Power Area and Arizona-New Mexico-Southern Nevada Power Area

13. WECC-CA - Western Electricity Coordinating Council / California

The ORCED model calculates the type of technology used for generation. By taking the difference between the base scenario and the PHEV scenarios, we can examine the technologies that will be used to generate the electricity for the PHEVs, which vary by region and by scenario. Table ES-1 gives a generalized description of how the fuels used to generate electricity change in each region, contrasting night charging and evening charging, for 2020 and 2030. Where the table identifies "gas" as the fuel, it may be used in combustion turbines, steam turbines, or combined cycle plants. More specific changes for each region are shown in figures in the body of the report. Figures ES-2 and ES-3 show the capacity, generation, and change in generation technologies for the sum of all regions in each of the years studied. 
Table ES-1. Generalized description of the types of fuels expected to be used to generate added electricity load for charging PHEVs in each region, 2020 and 2030

\begin{tabular}{rlcccc}
\hline & & \multicolumn{2}{c}{$\mathbf{2 0 2 0}$} & \multicolumn{2}{c}{$\mathbf{2 0 3 0}$} \\
\cline { 3 - 6 } & & $\begin{array}{c}\mathbf{1 0} \text { p.m. } \\
\text { charging }\end{array}$ & $\begin{array}{c}\mathbf{5} \text { p.m. } \\
\text { charging }\end{array}$ & $\begin{array}{c}\mathbf{1 0} \text { p.m. } \\
\text { charging }\end{array}$ & $\begin{array}{c}\mathbf{5} \text { p.m. } \\
\text { charging }\end{array}$ \\
\hline 1 & ECAR & $70 \%$ coal & $50 \%$ coal & $50 \%$ coal & $30 \%$ coal \\
2 & ERCOT & gas & gas & gas & gas + unserved \\
3 & MAAC & gas + coal & gas + oil & gas + coal & gas + oil \\
4 & MAIN & $75 \%$ coal & $50 \%$ coal & $40 \%$ coal & $25 \%$ coal \\
5 & MAPP & $50 \%$ coal & gas & $40 \%$ coal & gas \\
6 & NPCC-NY & oil + gas & oil + gas & gas & gas \\
7 & NPCC-NE & gas + coal & gas + oil & gas & gas + oil + coal \\
8 & FRCC & gas & gas + oil & coal + gas & gas + unserved \\
9 & SERC & $50 \%$ coal & $20 \%$ coal & $60 \%$ coal & $20 \%$ coal \\
10 & SPP & gas & gas & gas + coal & gas \\
11 & WECC-NW & gas & gas & gas & gas \\
12 & WECC-RMP/ANM & gas & gas & $80 \%$ coal & $25 \%$ coal \\
13 & WECC-CA & gas & gas & gas & gas + unserved \\
\hline Note: “Gas" may be used for combustion turbines, steam turbines, or combined cycle plants.
\end{tabular}

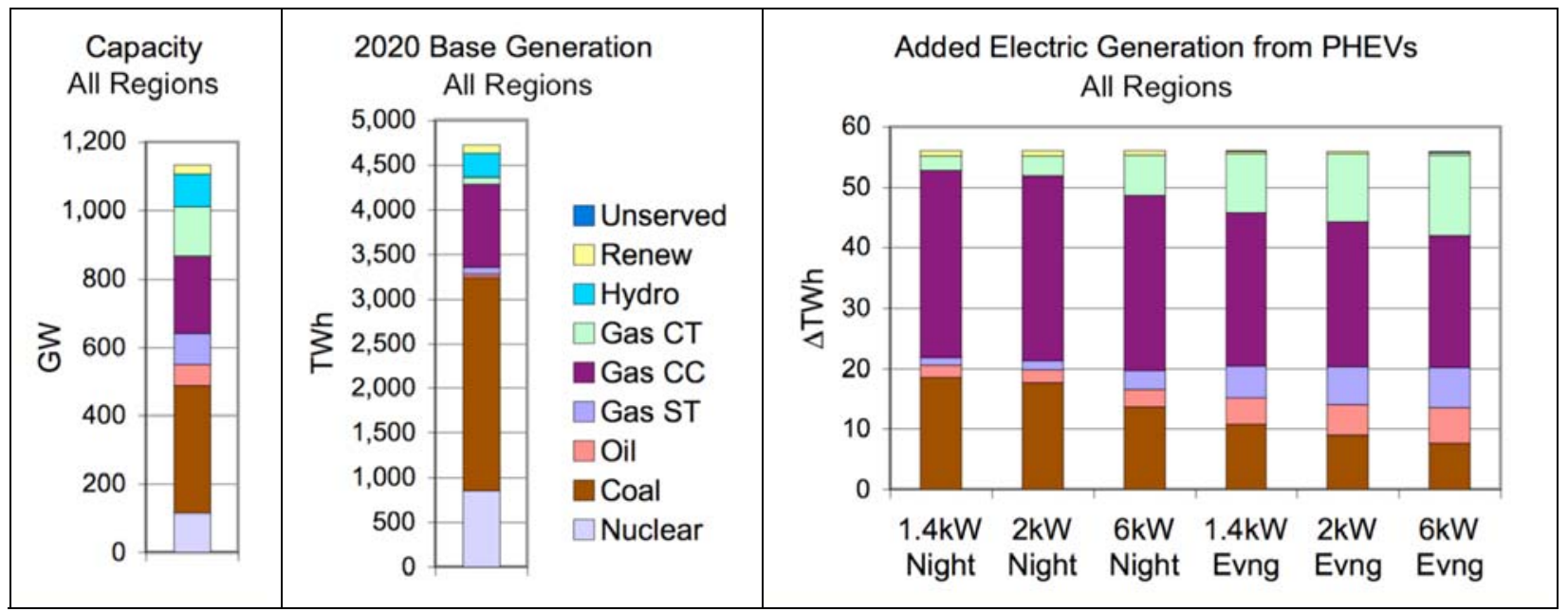

Figure ES-1. Sum for all regions of projected 2020 generating capacity (left), base generation (center), and new generation dispatched to meet demand for each PHEV recharging scenario (right). 


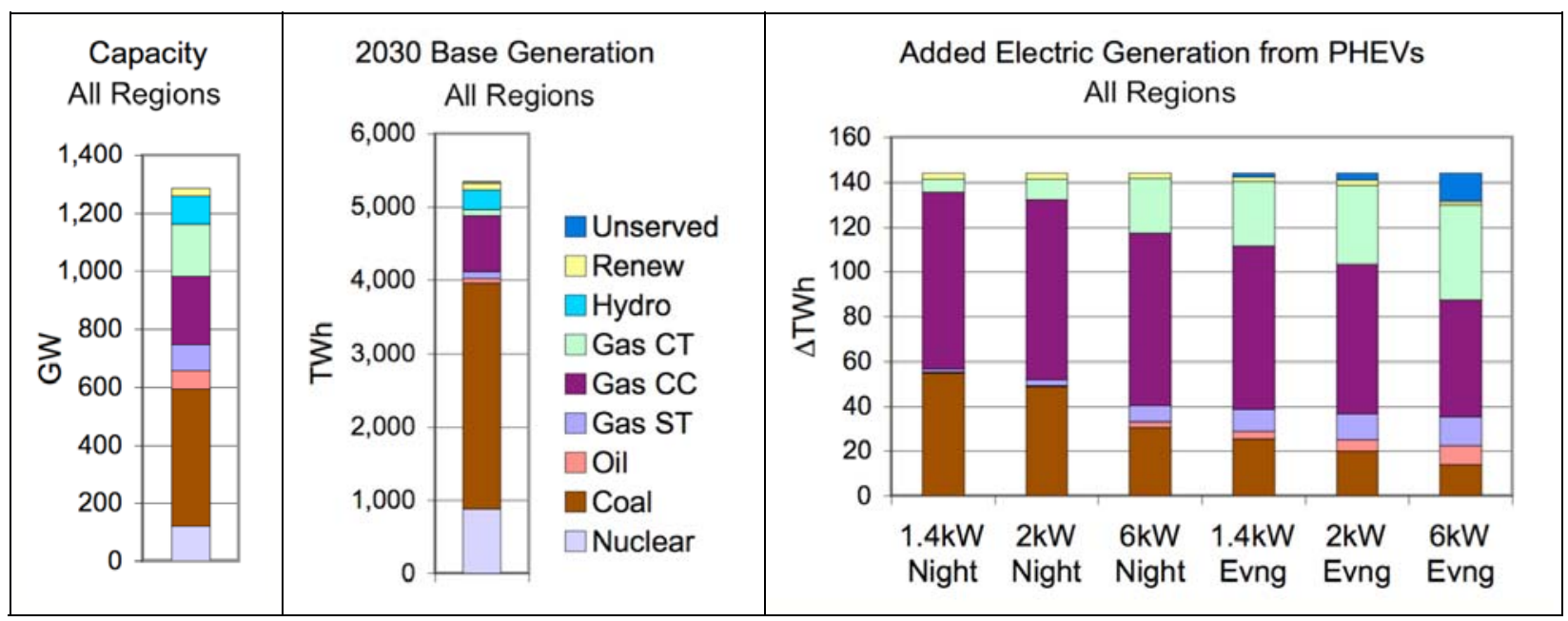

Figure ES-2. Sum for all regions of projected 2030 generating capacity (left), base generation (center), and new generation dispatched to meet demand for each PHEV recharging scenario (right).

$\mathrm{CO}_{2}, \mathrm{NO}_{\mathrm{X}}$, and $\mathrm{SO}_{2}$ emissions are calculated for the electricity generated. However, emissions of $\mathrm{NO}_{\mathrm{X}}$ in the eastern half of the country and $\mathrm{SO}_{2}$ in all of the country are limited by caps so that the total amount will not change; instead, those generating emissions over the limits will have to buy emissions credits from others who can reduce their emissions to compensate. So in effect, there are no increases in $\mathrm{SO}_{2}$ and only limited increases in $\mathrm{NO}_{\mathrm{X}}$ from this added generation. The market-based generation price and variable cost increase is also calculated over each year. In almost all cases, prices increase somewhat, with the largest impact from the evening scenarios where peaking power is needed. For those regions with insufficient capacity, the model calculates a cost of unserved energy that rises rapidly as the unserved amount increases. This can greatly increase average prices (except that in reality the regions will build additional capacity instead of allowing demand to go unserved).

A comparison was made of the fuel use, emissions, and cost of using a PHEV versus a clean, efficient hybrid electric vehicle (HEV) for each region, with both vehicles going 20 miles per day and the efficient HEV getting 40 miles per gallon. This is the simplest, most practical comparison: a PHEV that is recharged from the grid, versus a non-PHEV (or an owner who does not charge the battery from the grid). Table ES-2 shows the sum of all regions' values for the amount of fuel used (gasoline, fuel oil, coal, or natural gas), emissions, and the costs for 2-kW charging during the evening or later at night. $\mathrm{CO}_{2}$ emissions are slightly higher with PHEVs than gas-fueled HEVs in most scenarios because of the more carbon-intensive coal and oil (than gasoline), and/or the use of less efficient gas turbines and gas-fired steam turbines to meet the added generation needs. The $\mathrm{NO}_{\mathrm{x}}$ and $\mathrm{SO}_{2}$ emissions are much higher, but with the caveat that regulated caps will lower these values (through power plants adding scrubbers, catalytic reduction technologies, or fuel changes.) The cost of the gasoline at $\$ 3$ per gallon is much higher than the cost of the added electricity generation (fuel, operating costs, and unserved energy). This comparison does not include the added vehicle cost for the PHEV's battery or recharging capability, nor the full retail price paid for the electricity. 
Table ES-2. Comparison of fuels, emissions, and costs predicted for PHEVs using 2-kW recharging versus gasoline-fueled HEVs, sum of all regions, 2020 and 2030

\begin{tabular}{|c|c|c|c|c|c|c|}
\hline & \multicolumn{3}{|c|}{2020} & \multicolumn{3}{|c|}{2030} \\
\hline & Gasoline & 2 kW Night & $\begin{array}{c}2 \text { kW } \\
\text { Evening }\end{array}$ & Gasoline & 2 kW Night & $\begin{array}{c}2 \mathrm{~kW} \\
\text { Evening }\end{array}$ \\
\hline Vehicles (million) & 19.45 & & & 50.04 & & \\
\hline \multicolumn{7}{|l|}{ Fuel } \\
\hline - Oil (million barrel) & 84.5 & 4.2 & 10.4 & 217.5 & 0.5 & 11.8 \\
\hline - Coal (MTon) & & 9.26 & 4.84 & & 25.30 & 10.70 \\
\hline - Nat Gas (billion cuft) & & 270 & 367 & & 678 & 970 \\
\hline $\mathrm{CO}_{2}$ (MTon) & 34.4 & 37.8 & 36.9 & 88.5 & 94.5 & 86.1 \\
\hline${ }^{a} \mathrm{NO}_{\mathrm{x}}(\mathrm{kTOn})$ & 7.8 & 44.5 & 42.3 & 20.2 & 102.2 & 91.6 \\
\hline${ }^{a} \mathrm{SO}_{2}$ (kTon) & 0 & 246 & 288 & & 500 & 316 \\
\hline${ }^{b}$ Cost (\$million) & 10,647 & 2,500 & 3,294 & 27,399 & 6,186 & 12,858 \\
\hline
\end{tabular}

${ }^{a} \mathrm{NO}_{x}$ and $\mathrm{SO}_{2}$ emissions will be offset by reductions due to regulated caps.

${ }^{b}$ This comparison does not include the added vehicle cost for PHEV batteries or recharging capability, nor the full retail price of electricity.

This analysis identifies some of the complexities in analyzing an integrated system of PHEVs and the grid. Depending on the power level, timing, and duration of the PHEV connection to the grid, there could be a variety of impacts on grid constraints, capacity needs, emissions generated, and cost to the customer, utility, and society as a whole.

This analysis does use simplifications in modeling electric sector supply and demand. It applies rigid recharging schedules to all vehicles in each scenario, it does not adjust electricity supply to meet increased demand, its inventory of supply is based on results from a different model (the National Energy Modeling System, or NEMS) that simulates supply and demand somewhat differently, it does not model the transmission system, and it does not reflect all the complexities of air emissions regulations. However, it does offer insights into the issues involved with PHEVs and the electric grid. PHEV penetration of the vehicle market will potentially create a substantial change on the electric grid. By evaluating these issues early, DOE will be able to help utilities, manufacturers, and regulators understand the issues involved, suggest ideas that will better optimize the combined system, and help avoid negative consequences. 



\section{Introduction}

Plug-in hybrid electric vehicles (PHEVs) - cars, sport utility vehicles, pickup trucks, and others, that can be recharged from an ordinary electricity outlet in one's garage or elsewhere have recently become a popular topic of research and development. Major automotive manufacturers have proposed introduction of PHEVs into the world market. Toyota is currently testing a fleet of vehicles in Japan and California. General Motors has developed a prototype vehicle called the Chevrolet "Volt", which they prefer to call a plug-in electric vehicle (PEV) because the gas engine does not directly drive the wheels. Manufacturers, their suppliers, the electric industry, and government research institutions are continuing to develop the needed technologies to enable widespread use of PHEVs. It seems that general excitement with the idea of PHEVs springs from the perceived possibility of a "free lunch," which in this case is tripled. PHEVs promise to reduce dependence on foreign oil, reduce emissions, and help utilize generation capacity of the country that is idle during off-peak hours.

PHEVs offer the potential to reduce both gasoline consumption and associated emissions. According to some estimates, PHEVs that could travel up to 60 miles on a battery charge on electric energy stored in their batteries without recharge (PHEV60s) could reduce $\mathrm{CO}_{2}$ emissions by $50 \%$ and petroleum consumption by more than $75 \%$ (EPRI 2002). A recent DOE study suggests that "PHEVs will demonstrate a $50 \%$ reduction in fuel use over conventional vehicles when they are ready for market — possibly as early as 2010" (DOE 2006a). Many researchers have noted that the emissions reductions associated with PHEVs will depend on the regional mix of electricity generation technologies. The advantage of PHEVs is large in areas where electricity is generated with low carbon fuels, but is modest or nonexistent in regions with coal-based electricity generation (Kliersch and Langer 2006, Uhrig 2006). However, it is easier to control emissions from one central source than from millions of individual tailpipes.

Plug-in vehicle technology can help to address the "underutilization" of generation and transmission capacity in the country. Peculiarities of electricity generation and distribution technology, combined with an extremely volatile demand that must be satisfied at every location and every moment, require that the capacity and infrastructure is available for unexpected or expected surges in demand. Depending on climate zone, peak demand occurs during certain seasons (winter and/or summer) and certain times of day (afternoon and/or mornings). The rest of the time the grid and generating capacity is less fully utilized. What PHEVs are indeed able to do is to reduce the number of times generation plants are shut down and restarted, which guarantees cost savings on dispatching power (Parks, Denholm, and Markel 2007).

Researchers on PHEVs and the effects of their market penetration are generally enthusiastic about the ability of the present electricity infrastructure to accommodate increased demand associated with new types of vehicles, provided that recharging occurs during off-peak hours (Santini 2006; Parks, Denholm and Markel 2007). According to Kintner-Meyer, Schneider, and Pratt (2007, p.1) of the Pacific Northwest National laboratory:

"The U.S. electric power infrastructure is a strategic national asset that is underutilized most of the time. With the proper changes in the operational paradigm, it could generate and deliver the necessary energy to fuel the majority of the U.S. light duty vehicle fleet." 
Therefore, it might seem that there is a "free lunch" in a sense that, because of the infrastructure that is already in place, no additional investments are necessary to accommodate a technological breakthrough such as PHEVs.

There are some concerns, however, about whether this lunch is really "free." Increased electricity demand will extend the time during which electricity generators work at full capacity. It will accelerate amortization, increase opportunity costs of power plant withdrawals for planned operation and maintenance checks, and change the mix of marginal generators. The transmission grid will sway away from its customary "conservative" mode of operation to a fully loaded one. To assure reliability, new technology that is able to respond more quickly to changes in electrical properties of the line might be required. All in all, the "free lunch" may prove to be not so cheap.

With the argument that existing electricity generation and transmission capacity is sufficient to accommodate increased demand associated with PHEVs, provided that recharging occurs during off-peak hours (Kinter-Meyer, Schneider and Pratt 2007), the discussion so far has predominantly concentrated on technical and commercialization feasibility of efficient plug-in cars, while disregarding any potential constraints on the grid imposed by increased electricity demand. The implied assumptions may be mistaken. In reality it might prove extremely difficult to force consumers to charge their cars during some specified period of time, particularly if it is not convenient for them. Thus, further analysis is needed for researchers to understand the effects of PHEVs on electricity demand and grid performance if customers plug in when convenient for them rather than for utilities.

This paper forecasts the impacts of PHEVs on electricity demand, generation structure, and emissions levels in 2020 and 2030 in the 13 U.S. regions defined by the North American Electric Reliability Corporation (NERC) and the U.S. Department of Energy's (DOE's) Energy Information Administration (EIA). The paper extends the analysis undertaken in previous papers (Hadley 2006, Hadley 2007) into the year 2030 and presents more detailed results and discussion for every region of the country.

The authors used of the Oak Ridge Competitive Electricity Dispatch (ORCED) model to simulate the electricity demand and supply for the years 2020 and 2030. It uses public sources of electric power units from the National Energy Modeling System (NEMS) or other sources. The analysis uses hourly demand data from utility submittals to the Federal Energy Regulatory Commission (FERC) that are projected to future years. The model simulates a single region of the country for a given year and matches generation to demands, assuming no transmission constraints within the region and limited transmission in and out of the region.

ORCED can calculate a number of key financial and operating parameters for generating units, including average and marginal prices, air emissions, and generation adequacy. By running the model with and without demand changes such as PHEVs or distributed generation, the marginal impact of these technologies can be found.

The ORCED model has been used in a variety of studies:

- Impact of restructuring on power prices in California and the Pacific Northwest

- Potential for economic biomass cofiring on a state and regional basis 
- National carbon emissions under varied energy and carbon reducing scenarios

- Impacts of hydropower relicensing on carbon emissions in each NERC region

- Impacts of restructuring on prices and transmission in Oklahoma

- Market incentives for adequate generation capacity in a restructured electricity market

- Effect of $\mathrm{NO}_{\mathrm{X}}$ emission control implementation plans on system reliability

- Effect of carbon taxes on power production in the Midwest

- Benefits of multiple emissions controls strategies

- Benefits of distributed generation to utilities, customers, and society

- Air pollutant concentration changes across the Southeast due to demand reductions

- Impact of PHEVs on electricity generation in Virginia and the Carolinas

A second purpose of this study was to more fully develop and automate the ORCED model to enable it to be useful for a wider variety of studies. As shown in the list above, the model is capable of analyzing a number of critical issues facing the electricity sector and society. The hope is that making the model more accessible will enable others to use it for their own studies on different topics. To further this, a follow-on report will detail ORCED's operations, and the version that is currently available on the web, including the latest input data, will be updated.

The power-charging characteristics of PHEVs and a possible (though optimistic) projection of the PHEV market in the coming decades, which underlie the model's calculations, are described in Section 2 of this report. Chapter three describes regional electricity supply and demand, including the operations of the ORCED model. Chapter four presents the results for each region, beginning with a presentation of key results. Chapter five summarizes the results and presents conclusions. 


\section{PHEV Characteristics and Market}

PHEVs are similar to existing hybrids such as the Toyota Prius in that they use both gasoline and electric power. The difference is that PHEVs are able to recharge their batteries from the electricity wall outlet. PHEVs are expected to be able to travel 20 to 60 miles purely on electric power without recharge, which will require a larger and more efficient battery than current hybrids have.

As of early 2007, PHEVs are produced mostly as demonstration and prototype samples (Parks, Denholm and Markel 2007). The battery technology and cost of battery production seem to be the major impediments to the market expansion of PHEVs. Although tremendous progress has been made during the last decade in battery technology and electric drive systems, the estimates of price increments for plug-in cars range from $\$ 3000$ (DOE 2006) to $\$ 8000$ (Simpson 2006), or even \$10,000 (EPRI 2002, Kliesch and Langer 2006). Recently the technology shifted from nickel metal hydride to lithium-ion (Li-ion) batteries, which promise higher efficiency and cost savings but are still expensive to produce. Other options for the battery technology include lithium-metal-polymer, sodium/metal chloride, and nickel-zinc. The costs of these batteries must be reduced through economies of scale or technological advance before they will be commercially successful, and issues of performance, weight, and size still remain.

Nevertheless, there are signs that PHEVs are capable of displacing fleet petroleum consumption. A customer preference study indicates a definite, strong market potential for all PHEVs that is particularly large if cost equivalence with conventional vehicles is achieved. An important finding of the study is that the majority of respondents would prefer to charge a PHEV on their own premises to fueling it at a gasoline station (EPRI 2002). A survey conducted in 2006 indicates that about $70 \%$ of consumers are aware of PHEVs, more than half think that plug-in hybrids would be a good idea for their household, and about a third park their cars in garages or carports (where outlets are available or can be installed) (DOE 2006).

As discussed by Simpson (2006), PHEVs are “well-matched to motorists' driving habits." Travel survey data suggests that approximately $50 \%$ of vehicles travel less than 29 miles per day (Markel et al. 2006). Therefore, even PHEV30s (with a 30-mile range before recharging) are capable of displacing petroleum consumption equivalent to $40 \%$ of vehicle miles traveled. PHEV60s can displace about 60\% (Simpson 2006).

Another encouraging factor for PHEVs is the success of hybrid electric vehicles (HEVs) in the market. American consumers seem to be willing to pay a premium of a few thousand dollars to get cars that are more fuel efficient and environmentally friendly. Sales of conventional electric hybrid cars have grown (Ostroff 2007), and global hybrid vehicle production is approaching large-scale maturity with major improvements in performance and cost (Simpson 2006).

One more advantage of PHEVs from the consumer's perspective is its flexibility with respect to fuel use. Unlike HEVs and battery electric vehicles, PHEVs allow fuel substitution: the battery allows any fuel source that makes electricity to contribute, while the petroleum fuel tank allows it to travel long distances as conventional vehicles do. 
The last factor, which may be decisive in PHEV market penetration, is the role of the government. Congress continues to talk of increasing corporate average fuel economy standards, which would encourage the introduction of new and better technologies and make PHEVs one of the most viable alternatives. During the Tour de Sol race in 2005 in Schenectady and Albany, New York, a modified Prius equipped with a fully charged 9-kWh Li-ion battery achieved 102 mpg on a 240-km course (Jones 2005). PHEVs may also help curb U.S. dependency on oil imports, since the transportation sector consumes most of the oil used in the nation. Participants in a discussion on PHEVs held by DOE on May 4-5, 2006, said they thought that the federal government should be involved when national strategic interests are concerned. They listed at least three such interests with regard to PHEVs. First, energy security can be improved through a combination of PHEVs and non-petroleum electricity generation. Second, emissions can be reduced by using electricity from power plants that can be cleaner than internal combustion engines. Third, using electricity for transportation diversifies the energy source and reduces risks associated with disruptions in oil supply by maintaining mobility (DOE 2006).

\subsection{Number of Vehicles}

This analysis assumes considerable market penetration of the conventional vehicle fleet by PHEVs. For this study we use an estimate that PHEVs will achieve a constant $25 \%$ market share starting in 2020. Duvall's presentation (Duvall 2006) presents EPRI data showing a base case market potential of greater than $25 \%$ for the entire car and light-truck market regardless of commute distance. Following the 2002 report by the Electric Power Research Institute (EPRI), we assume a nominal vehicle life of ten years. To determine the possible total number of PHEVs on the roads in each year we used the annual vehicle sales projected from the AEO2007 (Figure $1)$.

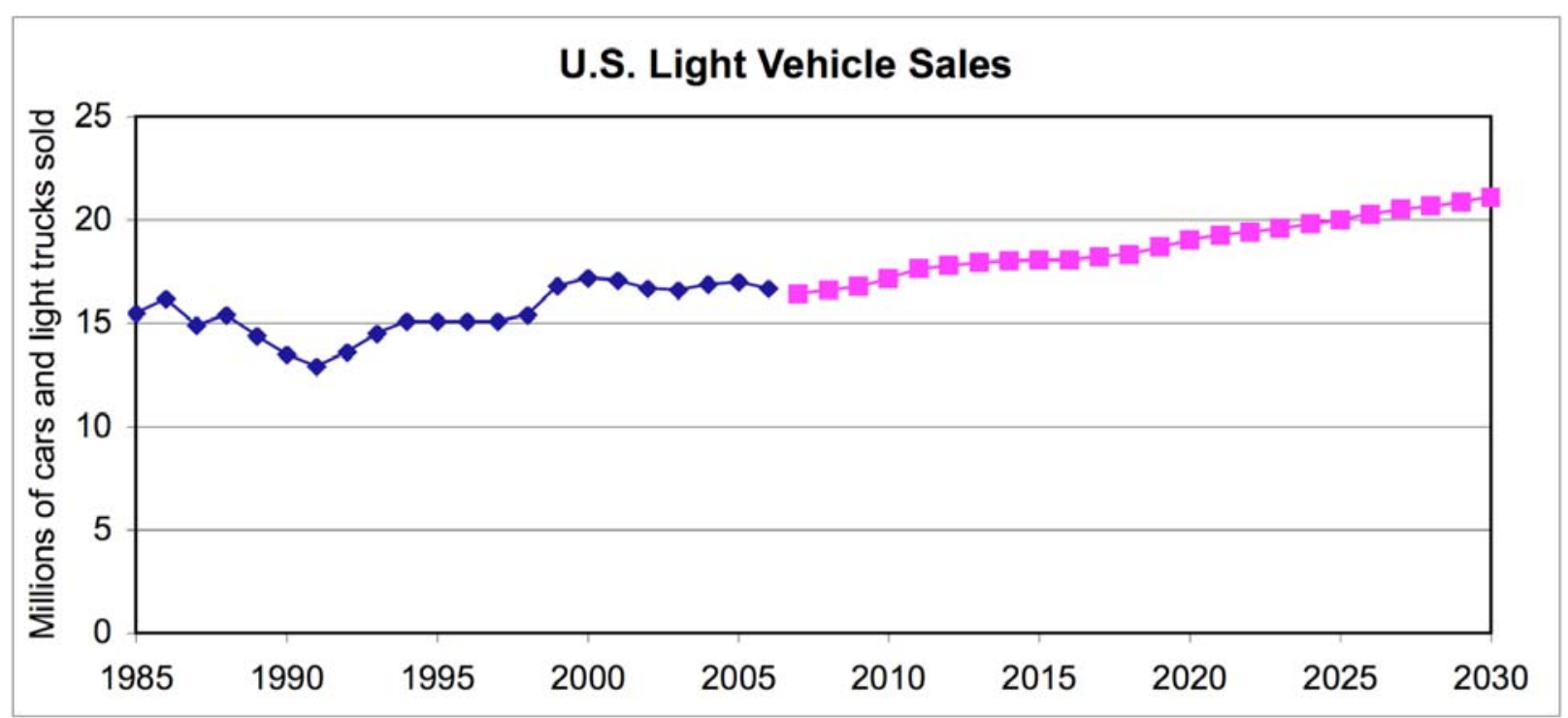

Figure 1. Past and projected vehicle sales in the United States.

For the purpose of this study we assume that the PHEV market share starts growing from $0 \%$ in 2010 to $25 \%$ by 2020 and stays at this level throughout the next decade (Figure 2). Combined with the projected vehicle sales between 2020 and 2030, the expansion path of PHEVs results in the number of plug-in hybrids sold each year as reflected in Figure 3. Assuming a useful service 
life of ten years, by 2030 only the PHEVs sold after 2020 will be running. This leaves the 2030 volume of vehicles lower than if the market share had continued to increase. However, since this analysis does not include adding generating capacity to supply the extra demand, we find that this level of penetration is sufficient to strain the system with evening charging, as shown later in this report.

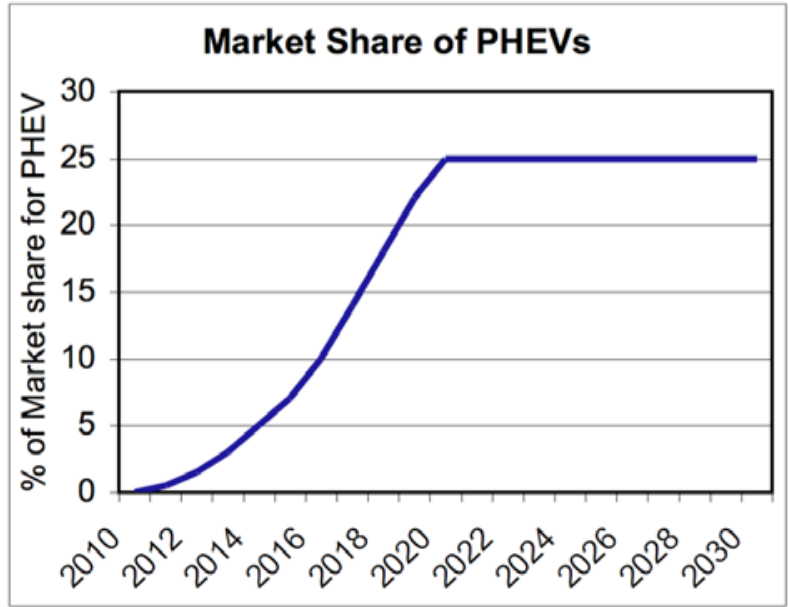

Figure 2. Projected market share of PHEVs.

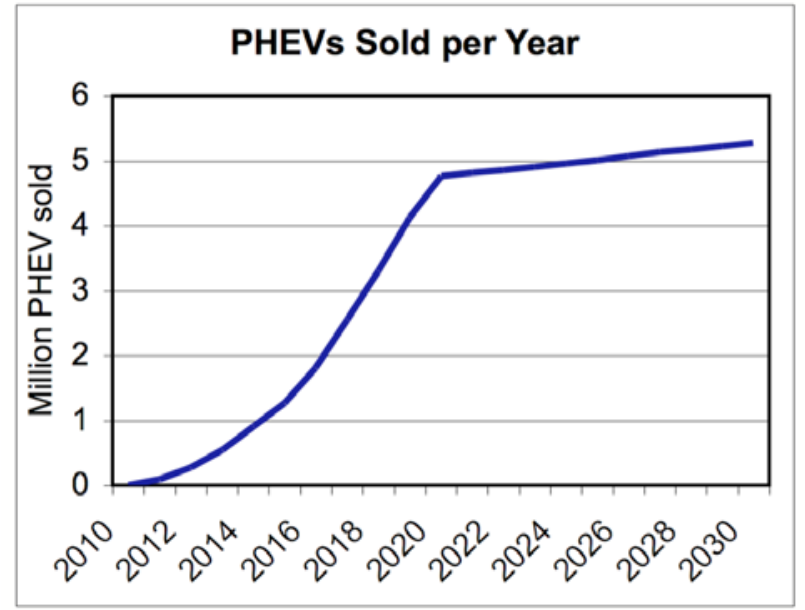

Figure 3. Projected number of PHEVs sold per year.

The analysis models each of 13 regions in the contiguous United States defined by NERC and DOE, and on which the analysis in Annual Energy Outlook 2007 (EIA) is based. (These regions are described more fully in chapter 3.) To determine the share of the total number of vehicles sold in each region, we used 2004 data for each state from the Bureau of Transportation Statistics (BTS 2005). We determined the registration ratios for automobiles, pickups, vans, and SUVs in each region to the national registration. Multiplying each year's market share for the PHEVs by the national sales amount and by the ratio determined for each region gives the corresponding annual sales of PHEVs for every region and for every year. Assuming the vehicles have a tenyear life, the sum of all PHEVs sold in every region between 2011 and 2020 (for the 2020 values) and between 2021 and 2030 (for the 2030 values) gives the estimate of the number of PHEVs on the road in the year evaluated (Table 1).

Table 1. Each region's share of total vehicles registered in 2004 and projected number of PHEVs in 2020 and 2030

\begin{tabular}{ll|c|c|c}
\hline & & $\begin{array}{c}\text { Percentage of total } \\
\text { vehicles registered } \\
(\mathbf{2 0 0 4 )}\end{array}$ & \multicolumn{2}{c}{ Projected number of PHEVs on the road (millions) } \\
\cline { 4 - 5 } Region & $12.4 \%$ & $\mathbf{2 0 2 0}$ & $\mathbf{2 0 3 0}$ \\
\hline 1 & ECAR & $7.2 \%$ & 2.44 & 6.27 \\
2 & ERCOT & $9.0 \%$ & 1.41 & 3.62 \\
3 & MAAC & $9.4 \%$ & 1.77 & 4.54 \\
4 & MAIN & $3.6 \%$ & 1.84 & 4.73 \\
5 & MAPP & $4.8 \%$ & 0.71 & 1.81 \\
6 & NPCC-NY & $5.2 \%$ & 0.94 & 2.42 \\
7 & NPCC-NE & $6.1 \%$ & 1.03 & 2.64 \\
8 & FRCC & 1.20 & 3.10 \\
\hline
\end{tabular}




\begin{tabular}{|c|c|c|c|c|}
\hline & \multirow[b]{2}{*}{ Region } & \multirow{2}{*}{$\begin{array}{l}\text { Percentage of total } \\
\text { vehicles registered } \\
\text { (2004) }\end{array}$} & \multicolumn{2}{|c|}{ Projected number of PHEVs on the road (millions) } \\
\hline & & & 2020 & 2030 \\
\hline 9 & SERC & $17.3 \%$ & 3.38 & 8.70 \\
\hline 10 & SPP & $2.2 \%$ & 0.44 & 1.13 \\
\hline 11 & WECC-NW & $5.3 \%$ & 1.04 & 2.67 \\
\hline 12 & WECC-RMP/ANM & $3.5 \%$ & 0.69 & 1.78 \\
\hline 13 & WECC-CA & $13.1 \%$ & 2.57 & 6.63 \\
\hline \multirow[t]{2}{*}{14} & Alaska and Hawaii & $0.7 \%$ & 0.14 & 0.35 \\
\hline & Totals & $100.0 \%$ & 19.58 & 50.39 \\
\hline
\end{tabular}

Using national registration data, we find that the ratio of automobiles to all types of vehicles (autos, light trucks, and SUVs) is 60\%. For our analysis we assumed the amounts were equally split between compact and mid-size sedans (30\% each) and mid-size and full-size light trucks and SUVs (20\% each).

\subsection{Charging Characteristics}

A key factor to understand is that the power demand on the grid from charging PHEVs will be a function of the voltage and amperage of the connection to the grid. The capacity of the battery will then determine the length of time it will take to recharge the battery, given the connection strength.

EPRI has conducted several studies on PHEV capabilities and issues. Dr. Mark S. Duvall's presentation at the DOE Plug-in Hybrid Electric Vehicles Workshop reviewed several characteristics for evaluating PHEV impacts on the grid (Duvall 2006). Duvall shows that there are many options for connecting vehicles to the grid. At 120 volts AC, a 15 amp circuit would be about a $1.4 \mathrm{~kW}$ load, while a 20 amp circuit would be about $2.0 \mathrm{~kW}$. Using a 208/240 volt and 30 amp circuit instead, the load could be as much as $6 \mathrm{~kW}$.

A comparison of times required for recharging is given in Table 2. This table, from the Duvall presentation, shows the time required for vehicles that have a 20-mile battery range (PHEV20) to recharge from $20 \%$ to $100 \%$ state of charge (SOC). Large battery packs (for longer range) would increase the time required for charging, while higher voltage or amperage would reduce it.

Table 2. Charging times required for PHEV20s for 20-100\% SOC, with $1.2-1.4 \mathrm{~kW}$ power and 1 or 2 hours conditioning (Duvall 2006)

\begin{tabular}{lccc}
\hline Type of PHEV20 & $\begin{array}{c}\text { Pack size } \\
\mathbf{( k W h )}\end{array}$ & $\begin{array}{c}\text { Charger circuit } \\
\text { (VAC / 15 A) }\end{array}$ & $\begin{array}{c}\text { Charging time } \\
\text { (hours) }\end{array}$ \\
\hline Compact sedan & 5.1 & 120 & $3.9-5.4$ \\
Mid-size sedan & 5.9 & 120 & $4.4-5.9$ \\
Mid-size SUV & 7.7 & 120 & $5.4-7.1$ \\
Full-size SUV & 9.3 & 120 & $6.3-8.2$ \\
\hline
\end{tabular}

Using the pack size from Table 2, a power level of $1.4 \mathrm{~kW}$, and an inverter loss of $15 \%$, we arrive at the approximations of the energy and time needed for recharging each PHEV shown in Table 3. 
Table 3. Power requirements and $\mathrm{kWh}$ demand by hour for PHEV20s at $120 \mathrm{~V} / 15 \mathrm{~A}$

\begin{tabular}{|c|c|c|c|c|c|c|c|c|c|}
\hline \multirow[b]{2}{*}{ Type of PHEV20 } & \multicolumn{8}{|c|}{ Hours charging } & \multirow[b]{3}{*}{ Demand (kWh) } \\
\hline & 1 & 2 & 3 & 4 & 5 & 6 & 7 & 8 & \\
\hline & \multicolumn{8}{|c|}{ Power requirements $(\mathrm{kW})$} & \\
\hline Compact Sedan & 1.4 & 1.4 & 1.4 & 1.4 & 0.4 & 0 & 0 & 0 & 6.0 \\
\hline Mid-size Sedan & 1.4 & 1.4 & 1.4 & 1.4 & 1.3 & 0 & 0 & 0 & 6.9 \\
\hline Mid-size SUV & 1.4 & 1.4 & 1.4 & 1.4 & 1.4 & 1.4 & 0.7 & 0 & 9.1 \\
\hline Full-size SUV & 1.4 & 1.4 & 1.4 & 1.4 & 1.4 & 1.4 & 1.4 & 1.1 & 10.9 \\
\hline
\end{tabular}

Assuming a constant energy requirement for fully charging the battery, higher voltages or current would reduce the time required to fully charge, as shown for each vehicle type in Figure 4. As the battery approached full charge, the actual demand curves would vary more and be dependent on other factors. In charging any battery, the amperage will vary as the battery approaches full state of charge, such that the power needs will fluctuate and tail off toward the end of the charging time. This is approximated in the table and calculations by having the last hour be only a partial charge. Our analysis only requires hourly values to match against hourly utility demand levels, as discussed below.

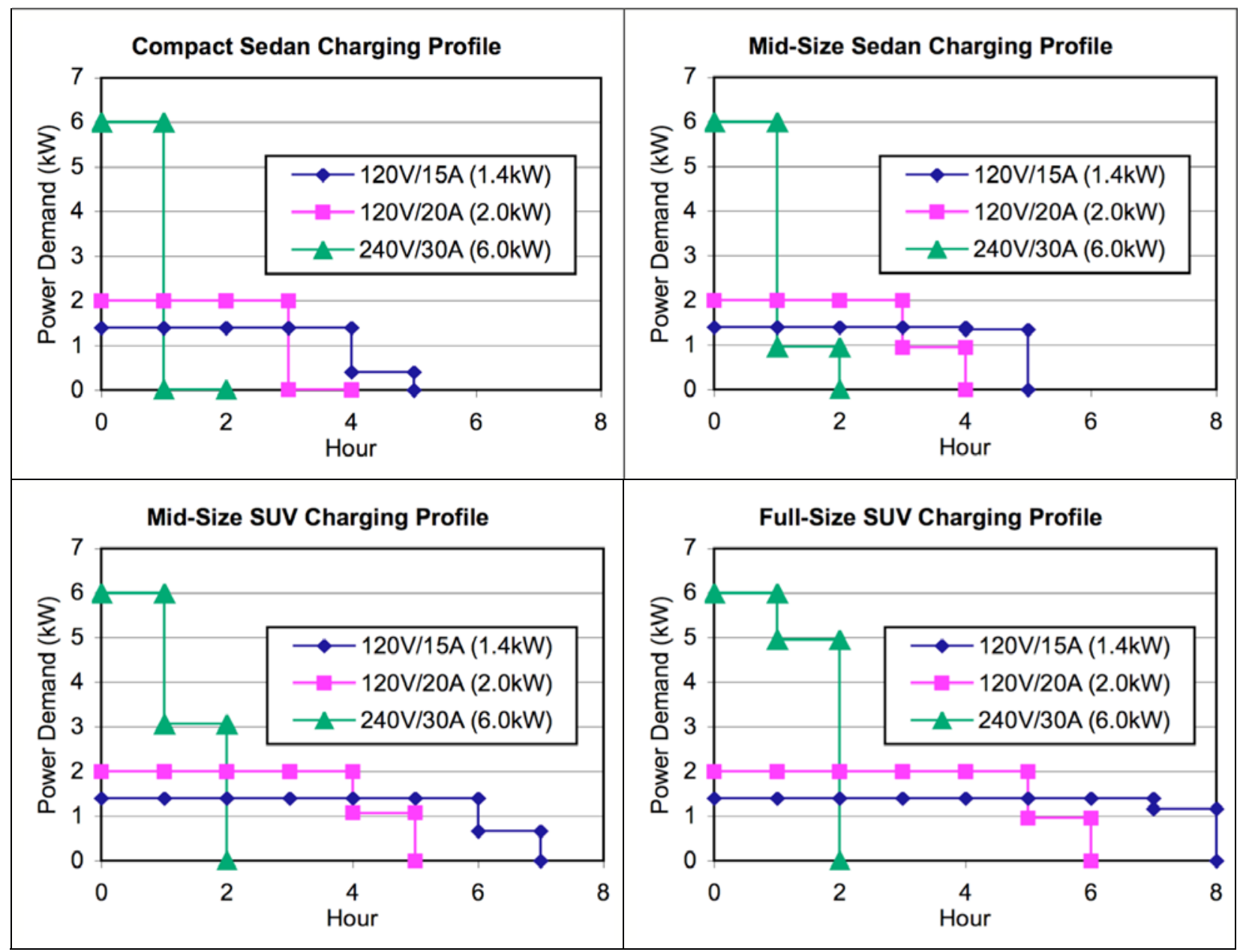

Figure 4. Hourly demand for a PHEV20vehicles at varying voltages and currents. 
Many cars will not be fully discharged (at 20\% SOC) when they are plugged in. Also, the owners may need to unplug them for travel before they are fully charged. These added complications are important, but will not be considered in this analysis.

\subsection{Timing of Plug-in}

A key question is when consumers would recharge their vehicles. The optimum time for electricity providers is typically at night when demand is low and low-cost plants are the marginal producers. Any additional generation would come from these low-cost plants and not strain the existing transmission and distribution system. However, for consumers the preferred time (absent any incentives to change their preferences) is likely to be as soon as they are within easy access to a plug. Charging at that time is most convenient because the driver is then at the vehicle already and will likely want to keep the battery as fully charged as possible in case the car is needed soon.

There are various ways for utilities to modify customer choices, including pricing schemes favoring nighttime charging or regulatory fiats on vehicle charging. Technically, it may be through smart chargers that know the price of power and/or driving habits of the owner. The intelligence could be in the charger or in the vehicle itself. Such questions are fertile areas for more extensive analysis but are beyond the scope of this paper.

Consumers could also recharge at their places of work, giving them additional range. Employers could offer this option as a benefit to employees, or local governments could offer daytime recharging to reduce afternoon air pollution (since more battery power would then be used during the evening commute.) Utilities and businesses could even install the infrastructure to allow consumers to plug in anywhere and have the cost of purchased power added to their bills.

There is also the idea of allowing PHEVs to provide power from their engines or batteries to feed the grid at times of peak demand, but further analysis is needed of this strategy's costs and benefits to consumers, the electric provider, and the environment. Additional circuitry would be required in vehicles, interconnection issues would add complications, battery life may be affected, and the pollution impact of the vehicles on air quality would have to be addressed. It may be that operating the vehicles to provide electricity to the grid may be more expensive and dirtier than building additional power plants.

For this analysis two options were modeled. For the evening charge half of the vehicles were plugged in at 5:00 p.m. and half at 6:00 p.m. For the night charge half were plugged in at 10:00 p.m. and half at 11:00 p.m. They then remained plugged in until fully charged, using the timeframes shown in Table 3 for the 120V/15A scenario and more rapid recharges at higher voltages and currents. The resulting weighted average profile is shown in Figure 5. In the evening scenarios the zero hour is $5 \mathrm{pm}$, while in the night scenarios it is $10 \mathrm{pm}$. For each region, the hourly demand from the curve is multiplied by the number of PHEVs on the road to get the hourly addition to the system electrical load. 


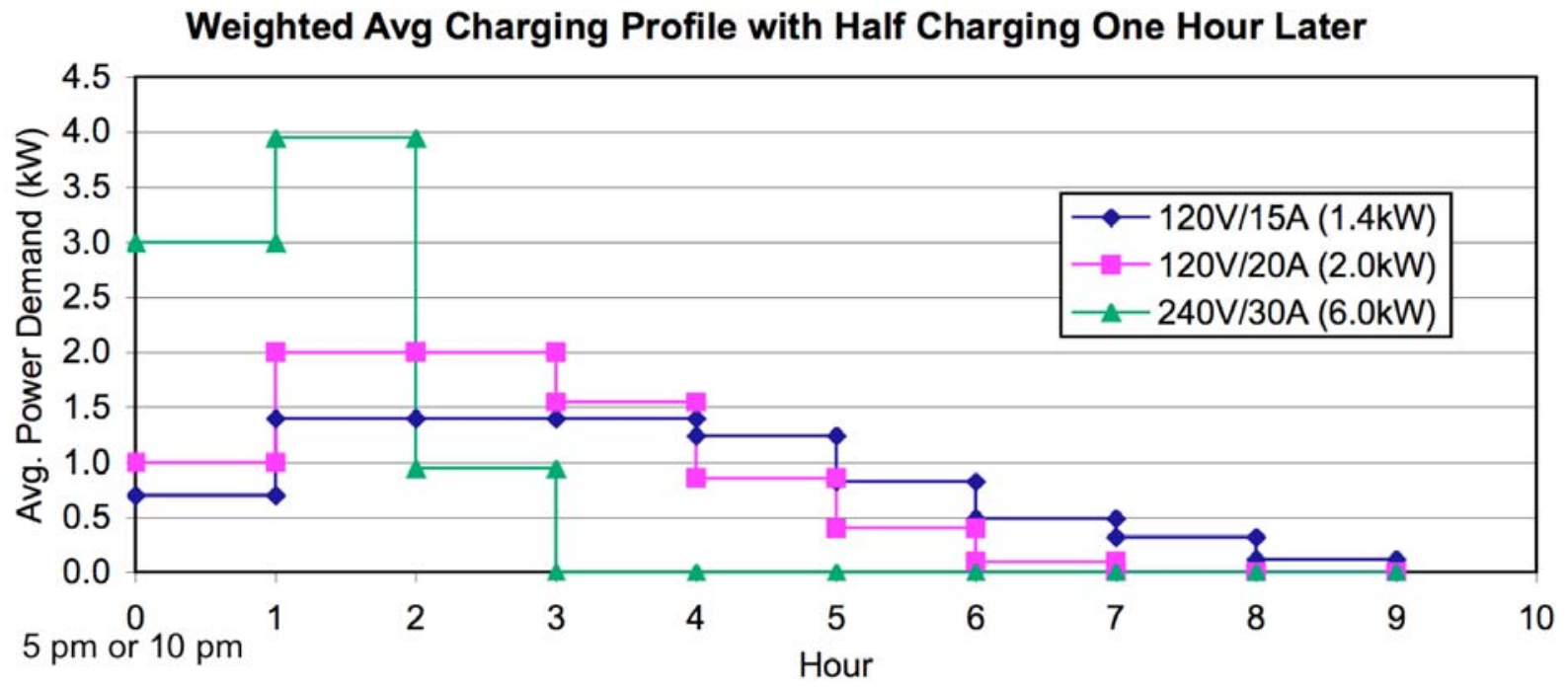

Figure 5. Weighted average charging profile for all vehicles with half charging one hour later. 


\section{Regional Electricity Supply and Demand}

\subsection{Overview}

To forecast the effects of PHEV market penetration on electricity demand, supply, price, and emissions, the authors used the ORCED model developed at Oak Ridge National Laboratory to examine numerous facets of a restructured electricity market. The model focuses on power generation, but also calculates a number of key financial and operating parameters. Several versions of the model have been developed over the years to address the particular needs of successive studies. The model's flexibility allows it to answer many different questions concerning the electric utility industry.

The ORCED model uses the collection of available electricity supply sources to dispatch plants to meet the defined demands for a single year of operation (Hadley and Hirst 1998). For this study, the program models the 13 NERC regions without transmission constraints within each region. Inter-regional transmission amounts are based on projections from Annual Energy Outlook 2007 for each region, with most sales occurring during the low and medium demand periods. The program can handle several thousand power plants and models three seasons: summer, winter and off-peak. Additional details on the model are included in a companion report (Hadley 2008).

\subsection{Definition of Regions}

Because of considerable regional variation in the mix of electricity generation types, capacity, and other factors related to generation and distribution, this analysis was performed on a regional basis, using the regions defined in Annual Energy Outlook 2007 (EIA 2007). The 13 regions are shown in Figure 6.

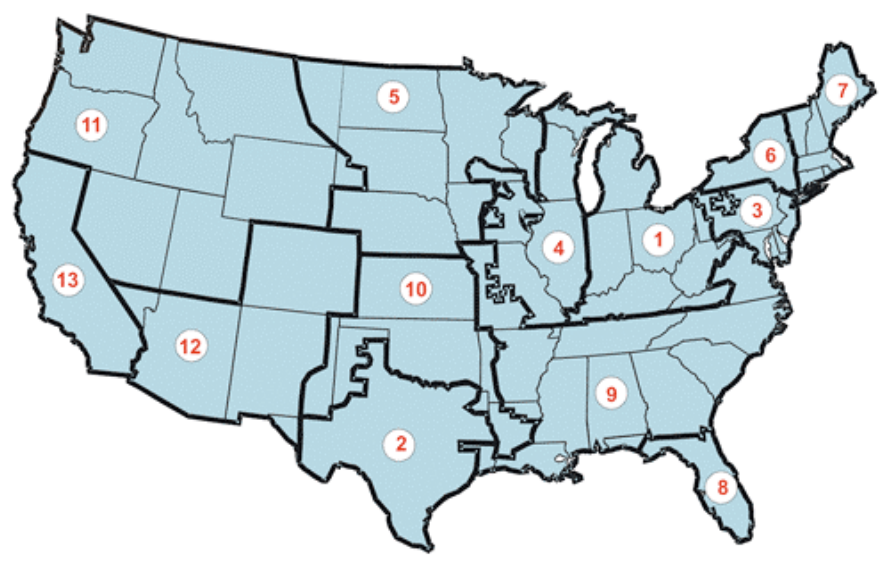

1. ECAR-East Central Area Reliability Coordination Agreement

2. ERCOT - Electric Reliability Council of Texas

3. MAAC - Mid-Atlantic Area Council

4. MAIN - Mid-America Interconnected Network

5. MAPP — Mid-Continent Area Power Pool

6. NPCC -NY - Northeast Power Coordinating Council / NY

7. NPCC -NE - Northeast Power Coordinating Council / New England

8. FRCC - Florida Reliability Coordinating Council;

9. SERC - Southeastern Electric Reliability Council

10. SPP - Southwest Power Pool

11. WECC-NW - Western Electricity Coordinating Council / Northwest Power Pool Area

12. WECC-RMP/ANM - Western Electricity Coordinating Council / Rocky Mountain Power Area and Arizona-New Mexico-Southern Nevada Power Area

13. WECC-CA - Western Electricity Coordinating Council / California

Figure 6. Regions as specified in Annual Energy Outlook 2007.

The names and borders of the regions have recently been changed, including merging of ECAR and MAAC, elimination of MAIN, and expansion of SERC. However, we used the regions shown in Figure 6 for this study because the Annual Energy Outlook 2007 data used in this analysis is based on those regions. 
There are two processing steps necessary to initiate the model: estimation of demand and estimation of supply. The model matches the supply to demand based on cost and other parameters in a simulation of how utilities dispatch the fleet of plants available.

\subsection{Demand Estimation}

Demand levels are estimated by first finding the hourly demands (loads) for the region of study. Many utilities are required to submit hourly load data to FERC, and this information for each control area for 2006 and earlier years is posted on the FERC Web site. Hourly load data for 2005 from about 85 utilities or control areas was retrieved and aggregated for each of the 13 regions. The resulting hourly loads were then escalated to match the regional total net electric load in the year being studied. Net inter-regional imports or exports from Annual Energy Outlook 2007 were then added to the loads, with transfers added mostly during lower demand periods and less at peak demand. As an example, Figure 7 gives the hourly loads for 2030 for the ECAR region. The year is separated into summer, winter, and off-peak seasons.

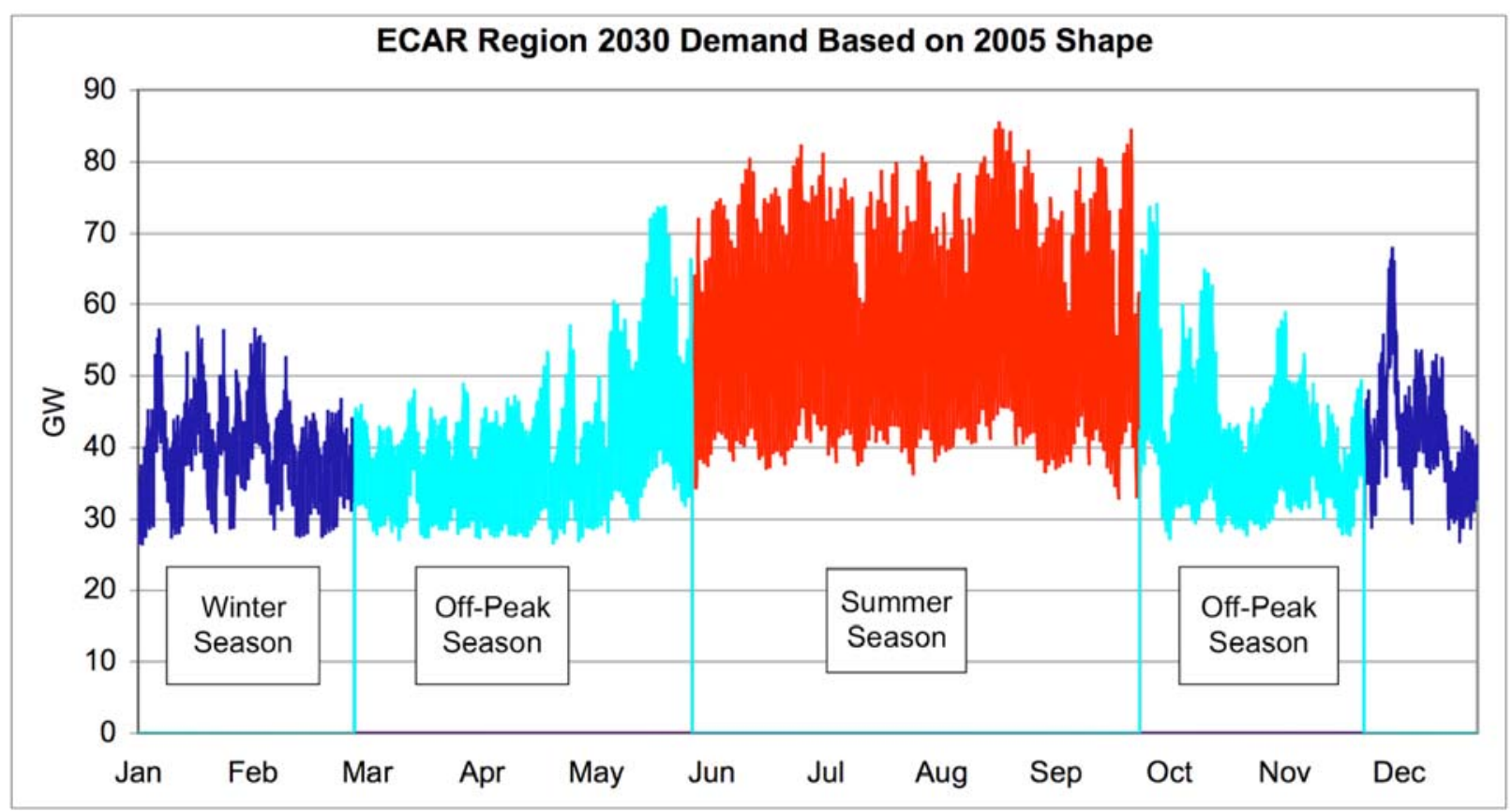

Figure 7. Hourly loads for ECAR in 2030 based on escalated 2005 loads.

Besides the base case with no PHEV included in demand, six scenarios of PHEV charging were modeled: three power levels at two time periods each, evening (beginning at 5 p.m.), and night (beginning at 10 p.m.) following the charging profiles from Figure 5. Table 4 shows the 2020 increased demand for each region in gigawatts, for each hour, due to charging PHEVs at a power level of $1.4 \mathrm{~kW}$ per vehicle. With power levels of $2 \mathrm{~kW}$ the charging is completed within 7 hours, and at $6 \mathrm{~kW}$ per vehicle, all charging is completed in 3 hours, but at higher rates, of course. The SERC region shows the largest increase in absolute power, $4.7 \mathrm{GW}$ in the second through fourth hour of charging. 
Table 4. Increased demand in 2020 in each region from charging PHEVs at $1.4 \mathrm{~kW}(\mathrm{GW})$, for each hour of charging time

\begin{tabular}{llllllllll}
\hline & \multicolumn{10}{c}{ Hour in charging period (9 hours total) } \\
\cline { 2 - 11 } Region & $\mathbf{1}$ & $\mathbf{2}$ & $\mathbf{3}$ & $\mathbf{4}$ & $\mathbf{5}$ & $\mathbf{6}$ & $\mathbf{7}$ & $\mathbf{8}$ & $\mathbf{9}$ \\
\hline ECAR & 1.7 & 3.4 & 3.4 & 3.4 & 3.0 & 2.0 & 1.2 & 0.8 & 0.3 \\
ERCOT & 1.0 & 2.0 & 2.0 & 2.0 & 1.8 & 1.2 & 0.7 & 0.5 & 0.2 \\
MAAC & 1.2 & 2.5 & 2.5 & 2.5 & 2.2 & 1.5 & 0.9 & 0.6 & 0.2 \\
MAIN & 1.3 & 2.6 & 2.6 & 2.6 & 2.3 & 1.5 & 0.9 & 0.6 & 0.2 \\
MAPP & 0.5 & 1.0 & 1.0 & 1.0 & 0.9 & 0.6 & 0.3 & 0.2 & 0.1 \\
NPCC-NY & 0.7 & 1.3 & 1.3 & 1.3 & 1.2 & 0.8 & 0.5 & 0.3 & 0.1 \\
NPCC-NE & 0.7 & 1.4 & 1.4 & 1.4 & 1.3 & 0.8 & 0.5 & 0.3 & 0.1 \\
FRCC & 0.8 & 1.7 & 1.7 & 1.7 & 1.5 & 1.0 & 0.6 & 0.4 & 0.1 \\
SERC & 2.4 & 4.7 & 4.7 & 4.7 & 4.2 & 2.8 & 1.6 & 1.1 & 0.4 \\
SPP & 0.3 & 0.6 & 0.6 & 0.6 & 0.5 & 0.4 & 0.2 & 0.1 & 0.1 \\
WECC-NW & 0.7 & 1.5 & 1.5 & 1.5 & 1.3 & 0.9 & 0.5 & 0.3 & 0.1 \\
WECC-RMP/ANM & 0.5 & 1.0 & 1.0 & 1.0 & 0.9 & 0.6 & 0.3 & 0.2 & 0.1 \\
WECC-CA & 1.8 & 3.6 & 3.6 & 3.6 & 3.2 & 2.1 & 1.3 & 0.8 & 0.3 \\
\hline
\end{tabular}

For a given region and year, the total increase in demand is the same for all scenarios. The changes in charging power level and time of charging simply shift the time of demand, but the total amount demanded is constant. Table 5 shows the increase in demand for each region. While the largest increase in absolute demand is in the SERC region, the largest on a percentage basis is in California because of the high penetration of vehicles in the state.

Table 5. Increase in electrical demand due to PHEVs for each region in 2020 and 2030

\begin{tabular}{l|c|c|c|c|c|c}
\hline Region & $\begin{array}{c}\text { Base } \\
\text { generation } \\
\text { (TWh) }\end{array}$ & $\begin{array}{c}\mathbf{2 0 2 0} \\
\text { Demand } \\
\text { with PHEVs } \\
\text { (TWh) }\end{array}$ & $\begin{array}{c}\text { Increase in } \\
\text { demand } \\
\text { (\%) }\end{array}$ & $\begin{array}{c}\text { Base } \\
\text { generation } \\
\text { (TWh) }\end{array}$ & $\begin{array}{c}\text { 2030 } \\
\text { Demand } \\
\text { with PHEVs } \\
\text { (TWh) }\end{array}$ & $\begin{array}{c}\text { Increase in } \\
\text { demand } \\
\text { (\%) }\end{array}$ \\
\hline ECAR & 695 & 702 & 1.0 & 703 & 721 & 2.6 \\
ERCOT & 363 & 367 & 1.1 & 413 & 424 & 2.5 \\
MAAC & 332 & 337 & 1.5 & 394 & 408 & 3.3 \\
MAIN & 373 & 378 & 1.4 & 365 & 378 & 3.7 \\
MAPP & 198 & 200 & 1.0 & 207 & 212 & 2.5 \\
NPCC-NY & 175 & 178 & 1.5 & 183 & 190 & 3.8 \\
NPCC-NE & 149 & 152 & 2.0 & 162 & 169 & 4.7 \\
FRCC & 281 & 285 & 1.2 & 340 & 349 & 2.6 \\
SERC & 1,053 & 1,063 & 0.9 & 1,268 & 1,294 & 2.0 \\
SPP & 231 & 232 & 0.5 & 283 & 286 & 1.2 \\
WECC-NW & 299 & 302 & 1.0 & 326 & 334 & 2.4 \\
WECC-RMP/ANM & 301 & 303 & 0.7 & 347 & 352 & 1.5 \\
WECC-CA & 277 & 284 & 2.7 & 348 & 367 & 5.5 \\
\hline
\end{tabular}

A key value is the peak demand, whether it is at $6-7$ p.m. in the evening scenarios or $11-12$ p.m. in the night scenarios. The power level per vehicle has a significant effect on the peak, as 
shown in Table 6 . The $6 \mathrm{~kW}$ scenarios have by far the highest peak levels, with demand rising more than $34 \mathrm{GW}$ in SERC by 2030.

Table 6. Highest demand increase from PHEV charging at each power level in 2020 and 2030, in each region $(G W)$

\begin{tabular}{lccc|rrr}
\hline \multicolumn{1}{c}{ Region } & \multicolumn{3}{c|}{2020} & \multicolumn{3}{c}{2030} \\
\hline ECAR & $1.4 \mathrm{~kW}$ & $2 \mathrm{~kW}$ & $6 \mathrm{~kW}$ & $1.4 \mathrm{~kW}$ & $2 \mathrm{~kW}$ & $6 \mathrm{~kW}$ \\
ERCOT & 3.4 & 4.9 & 9.6 & 8.8 & 12.5 & 24.8 \\
MAAC & 2.0 & 2.8 & 5.6 & 5.1 & 7.3 & 14.3 \\
MAIN & 2.5 & 3.5 & 7.0 & 6.4 & 9.1 & 17.9 \\
MAPP & 2.6 & 3.7 & 7.3 & 6.6 & 9.5 & 18.7 \\
NPCC-NY & 1.0 & 1.4 & 2.8 & 2.5 & 3.6 & 7.2 \\
NPCC-NE & 1.3 & 1.9 & 3.7 & 3.4 & 4.8 & 9.5 \\
FRCC & 1.4 & 2.1 & 4.1 & 3.7 & 5.3 & 10.4 \\
SERC & 1.7 & 2.4 & 4.8 & 4.3 & 6.2 & 12.2 \\
SPP & 4.7 & 6.8 & 13.3 & 12.2 & 17.4 & 34.3 \\
WECC-NW & 0.6 & 0.9 & 1.7 & 1.6 & 2.3 & 4.5 \\
WECC-RMP/ANM & 1.5 & 2.1 & 4.1 & 3.7 & 5.3 & 10.6 \\
WECC-CA & 1.0 & 1.4 & 2.7 & 2.5 & 3.6 & 7.0 \\
\hline
\end{tabular}

Since the added demand for PHEVs does not fall at the absolute peak for the year, each system's peak does not rise as much as the demand increases shown in Table 6. The amount the system's peak rises depends on both the charging power level and the timing. Figure 8 shows the impact of the added power for each of the scenarios on the peak day for the ECAR region in 2020 (July 25). Only in the $6 \mathrm{~kW}$ evening scenario is the system peak increased by the added PHEVs. The other scenarios spread the generation over longer time periods and/or shift it to off-peak hours.

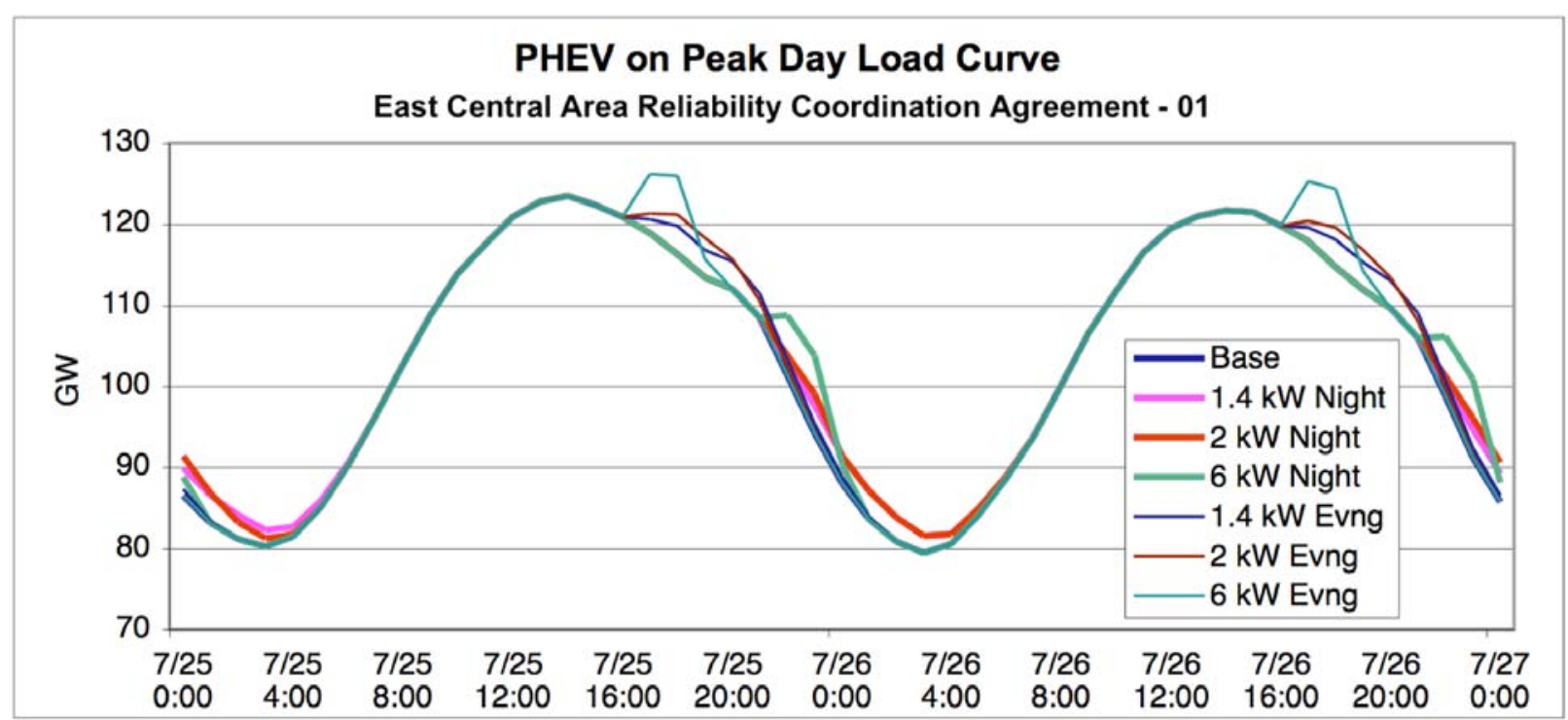

Figure 8. Added demand from PHEV charging scenarios on the peak day in ECAR for 2020. 
While PHEV charging can have an impact on the peak days, on most other days the addition does not raise demand over the annual peak. The 2030 scenarios show a more marked rise in the demand profiles due to PHEVs. The impact of charging during the evening is significant, but charging during nighttime has no impact on capacity requirements. Figure 9 shows the impact of the $2 \mathrm{~kW}$ charging scenario on ECAR in 2030 during the peak week during the summer, winter, and off-peak seasons. Note that even though the $2 \mathrm{~kW}$ charging scenario is not the one with the largest capacity demand, it still raises the system peak during the evening scenario. The summer peak is still the overall annual peak, and the evening charging does not occur during the day's overall peak, so demand increases are not abrupt. In the winter season, the PHEV evening demands are sufficient to change the profile from peaking in the morning to peaking in the evening. The off-peak season curves have a later peak than summer, so the PHEV addition has a larger impact on the day's overall peak.

It is clear that in all cases, the nighttime charging "fills in the valley" and so provides a more level load profile than the evening charging. Since utilities would prefer the increased utilization of existing capacity rather than having to build additional capacity, they would be expected to prefer nighttime charging.

While the figures here show the profiles for ECAR, other regions of the country show similar curves. There are differences depending on the unique characteristics of each region, such as the timing of peak load both within the day and over the course of the year.

After the hourly demands are found for every region, they must be converted into load duration curves (LDCs) for summer, winter and off-peak seasons (Figure 10). The LDC reorders demand by increasing power levels and so shows the percentage of time that demand equals or exceeds a given power level. Three separate curves were developed to determine power plant production in each season. For the purposes of ORCED operation, the LDCs need to be linearized to 11segment lines. These are done using the Excel Solver function to fit points to the lines while minimizing the variance and keeping the total production constant.

When PHEVs are added to the LDC for each region, the curves will rise. When added during the nighttime, the lower demand values are preferentially raised (on the right side of the graphs), while the evening scenarios preferentially raise the left side of the graphs. Figure 11 shows the impact of adding the $2 \mathrm{~kW}$ evening charging and night charging scenarios to the ECAR region in 2030. The annual peak rises 5.4\%, but in other regions with a higher percentage of vehicles and in the $6 \mathrm{~kW}$ evening scenario the difference is more pronounced. California has a $9 \%$ rise in the peak by 2020 and a $28 \%$ rise by 2030 .

Table 7 shows the increase in the annual peak for each region using the $6 \mathrm{~kW}$ evening charging scenario in 2020 and 2030. These peak increases only apply if all vehicles use the $6 \mathrm{~kW}$ evening charge schedule. In 2020, at $2 \mathrm{~kW}$, only nine regions show any increase in their annual peak, and at $1.4 \mathrm{~kW}$, only seven. The peak is not affected if charging is done at night. With the larger number of vehicles in 2030, all of the regions see new peaks if vehicles charge in the evening, regardless of the power level. So even though the total energy demand increase from PHEVs is in the range of $1-5 \%$ (Table 5), the peak capacity demand ranges from no change to $28 \%$ higher in our scenarios. 


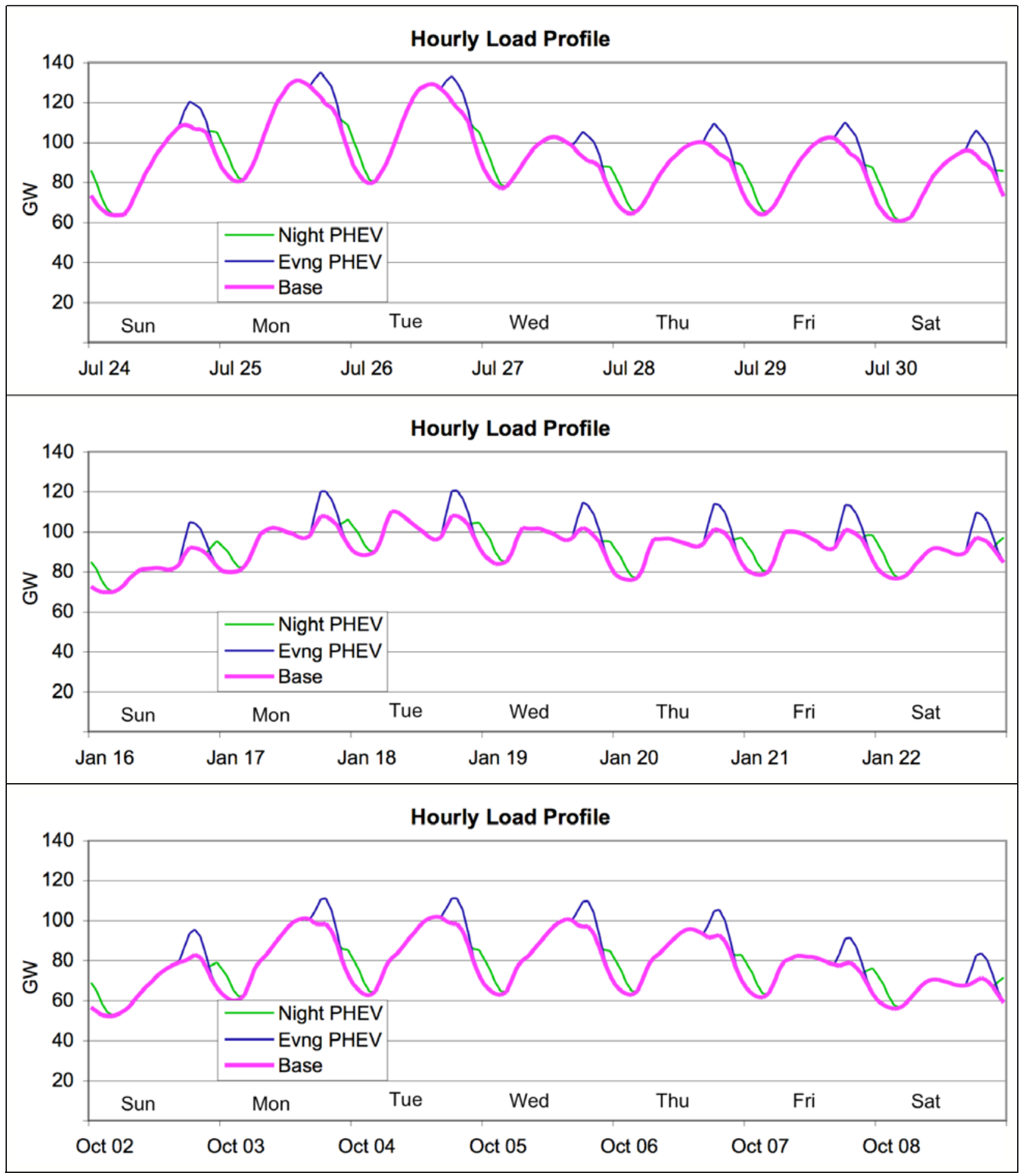

Figure 9. Added demand from the $2 \mathrm{~kW}$ PHEV charging scenarios on the peak weeks in summer (top), winter (middle), and off-peak (bottom) seasons in ECAR for 2030. 


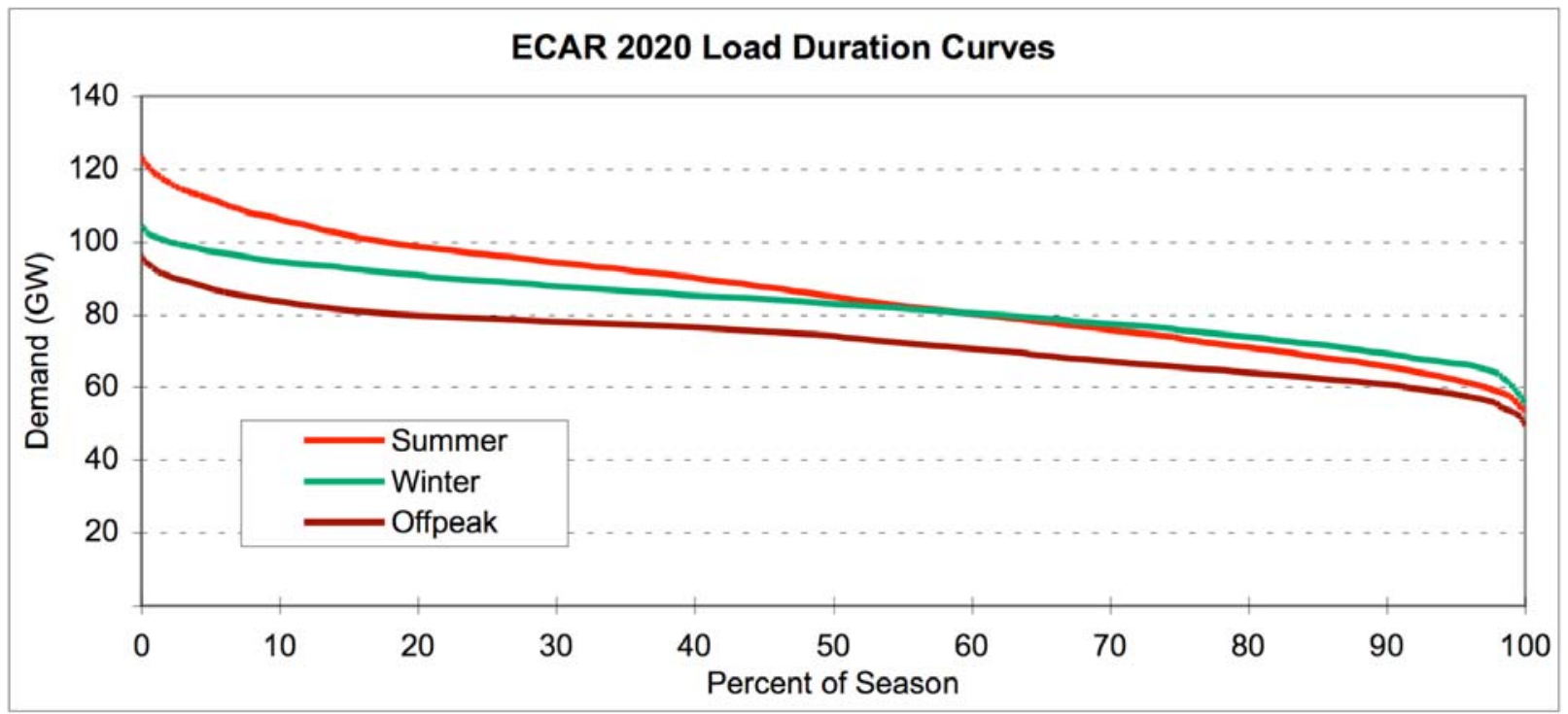

Figure 10. Load duration curve for ECAR in 2020 with no PHEVs.

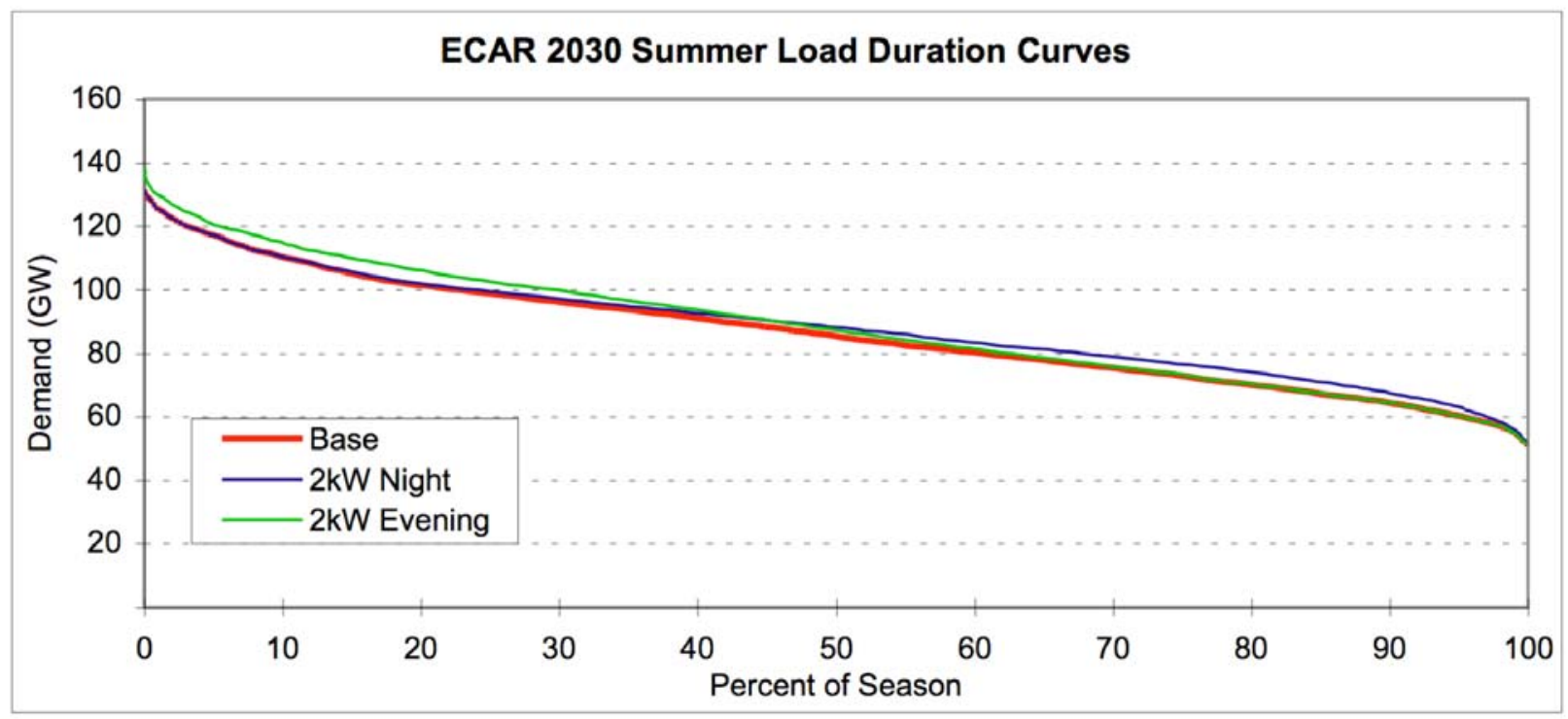

Figure 11. Summer $L D C$ for the ECAR region in 2030 showing no PHEVs and with charging at $2 \mathrm{~kW}$ in the evening and night. 
Table 7. Increase in annual peak demand with PHEV charging at $6 \mathrm{~kW}$ in the evening

\begin{tabular}{lcc|cc}
\hline \multicolumn{2}{c|}{2020} & \multicolumn{2}{c}{2030} \\
\hline ECAR & Peak increase (GW) & Increase (\%) & Peak Increase (GW) & Increase (\%) \\
ERCOT & 5.2 & 4.2 & 19.3 & 14.7 \\
MAAC & 3.5 & 4.5 & 10.9 & 12.7 \\
MAIN & 4.3 & 6.0 & 15.3 & 19.4 \\
MAPP & 6.4 & 10.1 & 16.9 & 24.4 \\
NPCC-NY & 2.5 & 7.4 & 6.9 & 18.5 \\
NPCC-NE & 2.4 & 6.9 & 7.9 & 21.8 \\
FRCC & 1.6 & 4.9 & 7.4 & 21.7 \\
SERC & 3.3 & 5.3 & 10.2 & 13.7 \\
SPP & 6.4 & 1.2 & 25.9 & 10.8 \\
WECC-NW & 0.6 & 6.9 & 2.7 & 4.9 \\
WECC-RMP/ANM & 3.2 & 2.3 & 9.4 & 17.9 \\
WECC-CA & 1.3 & 9.0 & 4.2 & 6.4 \\
\hline
\end{tabular}

Figure 12 and Figure 13 below show the changes in the LDC for the summer season of ECAR in 2020. (The pink line in each graph represents the difference between the $2 \mathrm{~kW}$ scenario and the base scenario in Figure 11.) These curves are not smooth (and some values go slightly negative) because the graphs take the difference between the 12-point linearized LDCs used by the ORCED dispatch model, rather than the original curves. The total area under each curve is the same for each, representing the amount of energy demanded by the PHEVs. In most scenarios, the peak impact is less than $2000 \mathrm{MW}$, but in the $6 \mathrm{~kW}$ evening scenario, the peak demand rises to $5200 \mathrm{MW}$. This is because the highest demand occurs near the peak demand for the system. Note that in Table 6 the peak power added by PHEV is 9600 MW. However, this demand is not at the same time as the system peak, so the system peak only rises by $5200 \mathrm{MW}$. When the demand is added at lower power levels, the calculation of the LDC moves those hourly values to the left in the graph, so the net rise is less than the specific hour's rise in demand.

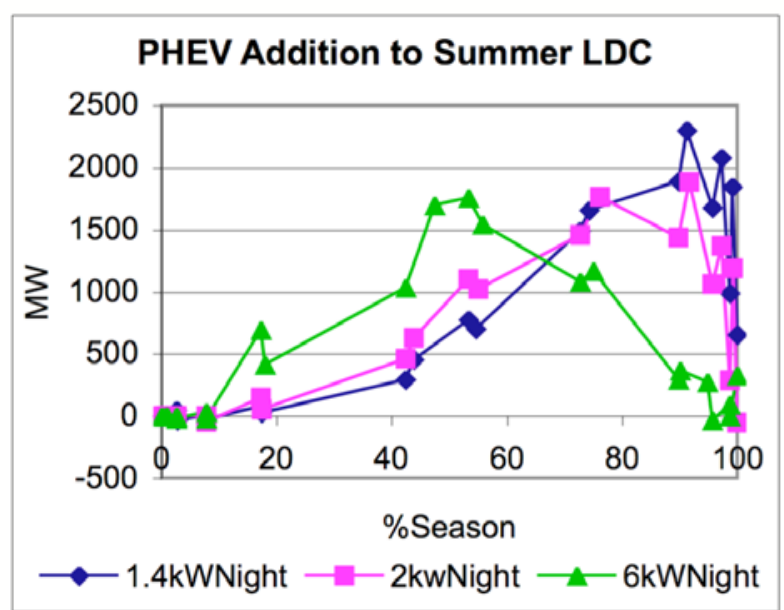

Figure 12. Addition of PHEV night charging to ECAR 2020 summer season LDC.

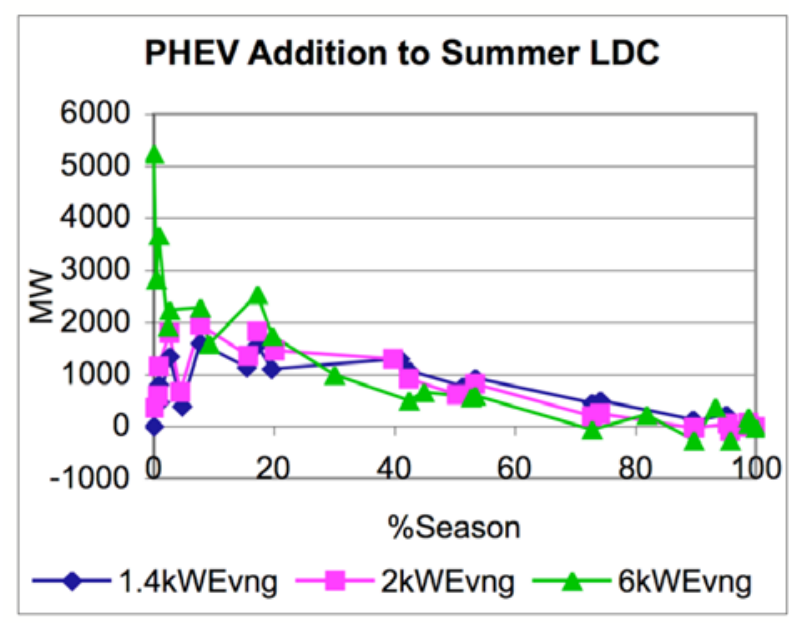

Figure 13. Addition of PHEV evening charging to ECAR 2020 summer season LDC. 


\subsection{Supply Estimation}

First, the plants for a modeled region must be determined. For this analysis, the key plant lists come from the Energy Information Administration's Annual Energy Outlook 2007 (EIA 2007) and the model used to create the report, the National Energy Modeling System (NEMS).

One input file to the NEMS includes a list of 21,000 generating units in the country. This list contains a large number of parameters for each unit, including summer capacity, winter capacity, heat rate, generating technology, fuel type, emission rates, operating costs, and age. Fuel costs are not specified since they vary by year and type of fuel. However, fuel cost per million Btu for each region and year is an output of NEMS that can be used to approximate the fuel costs for each plant. In addition, the NEMS model calculates the amount of additional capacity needed for each region and simulates the construction of this capacity. The amount added each year can be calculated, and the necessary parameters for ORCED can be found from the input files or the output tables.

The list of plants for a region are then ordered by technology, fuel type, and variable cost. This list is then separated into up to 200 bins that capture the weighted average values of the plants in each bin. The resulting table of plants, with key modeling parameters, is passed to the ORCED dispatch model.

Table 8 shows the nameplate capacity of the mix of plants for each region in 2020. Summer and winter capacities can be greater or less than nameplate, and ORCED uses the appropriate amounts available for each season. These seasonal capacities are shown in each region's results in Section 4. A question arises about whether the NEMS model constructed enough additional capacity or too much for a given region, because NEMS uses a more simplified LDC than ORCED. However, NEMS includes some production sales between regions, limited by transmission constraints. The timing of these sales or purchases can modify the LDC so that capacity can be sufficient for the regions. ORCED accounts for this by adjusting the LDC to satisfy the production amounts from NEMS, with changes in the LDC affecting mainly the midrange and lower demand levels.

Table 8. Power plant nameplate capacity by region in 2020 (GW)

\begin{tabular}{|c|c|c|c|c|c|c|c|c|c|c|c|c|c|}
\hline & ECAR & ERCOT & MAAC & MAIN & MAPP & $\begin{array}{c}\text { NPCC- } \\
\text { NY }\end{array}$ & $\begin{array}{l}\text { NPCC- } \\
\text { NE }\end{array}$ & FRCC & SERC & SPP & $\begin{array}{c}\text { WECC- } \\
\text { NW }\end{array}$ & $\begin{array}{c}\text { WECC- } \\
\text { RMP/A } \\
\text { NM }\end{array}$ & $\begin{array}{c}\text { WECC- } \\
\text { CA }\end{array}$ \\
\hline Coal Unscrub & 58.7 & 6.0 & 14.9 & 29.7 & 10.7 & 2.0 & 2.2 & 2.7 & 49.6 & 13.9 & 2.6 & 4.2 & 0.0 \\
\hline Coal Scrub & 31.0 & 10.6 & 11.2 & 5.9 & 10.2 & 1.3 & 1.1 & 11.2 & 35.7 & 8.7 & 12.7 & 24.2 & 10.8 \\
\hline Oil Steam & 0.7 & 0.0 & 7.2 & 0.4 & 0.3 & 8.0 & 5.9 & 6.5 & 2.1 & 2.5 & 0.0 & 0.0 & 0.2 \\
\hline Oil Turbine & 1.8 & 0.0 & 4.7 & 2.1 & 2.9 & 1.8 & 1.8 & 4.1 & 5.3 & 1.5 & 0.1 & 0.4 & 0.5 \\
\hline Oil Comb Cycle & 0.0 & 0.0 & 0.6 & 0.0 & 0.0 & 0.0 & 0.0 & 1.1 & 0.1 & 0.0 & 0.0 & 0.0 & 0.0 \\
\hline Gas Steam & 3.6 & 27.3 & 0.6 & 0.6 & 0.1 & 3.7 & 1.7 & 4.7 & 18.4 & 11.0 & 0.8 & 4.9 & 14.3 \\
\hline Gas Comb Cycle & 13.5 & 31.7 & 15.8 & 7.4 & 2.4 & 10.9 & 14.7 & 21.2 & 45.0 & 12.7 & 9.6 & 21.9 & 18.8 \\
\hline Gas Turbine & 22.5 & 11.7 & 8.0 & 18.7 & 6.7 & 3.6 & 1.8 & 9.2 & 34.8 & 7.6 & 2.6 & 6.9 & 6.8 \\
\hline Nuclear & 8.3 & 5.4 & 13.1 & 15.3 & 3.0 & 6.3 & 3.9 & 4.1 & 45.2 & 1.2 & 1.2 & 4.2 & 4.6 \\
\hline Solid Waste & 0.3 & 0.1 & 0.8 & 0.3 & 0.2 & 0.4 & 0.7 & 0.5 & 0.4 & 0.0 & 0.1 & 0.0 & 0.4 \\
\hline Biomass & 0.5 & 0.0 & 0.1 & 0.0 & 0.3 & 0.1 & 1.4 & 0.5 & 0.6 & 0.0 & 0.5 & 0.1 & 0.6 \\
\hline Distrib Gen & 0.0 & 0.6 & 0.6 & 0.0 & 0.1 & 0.0 & 0.2 & 0.2 & 0.1 & 0.0 & 0.3 & 0.0 & 0.1 \\
\hline Other Renew & 0.1 & 2.6 & 0.3 & 0.5 & 1.9 & 0.3 & 0.0 & 0.1 & 0.1 & 1.6 & 2.3 & 0.8 & 3.3 \\
\hline
\end{tabular}




\begin{tabular}{|c|c|c|c|c|c|c|c|c|c|c|c|c|c|}
\hline & ECAR & ERCOT & MAAC & MAIN & MAPP & $\begin{array}{c}\text { NPCC- } \\
\text { NY }\end{array}$ & $\begin{array}{l}\text { NPCC- } \\
\text { NE }\end{array}$ & FRCC & SERC & SPP & $\begin{array}{c}\text { WECC- } \\
\text { NW }\end{array}$ & $\begin{array}{c}\text { WECC- } \\
\text { RMP/A } \\
\text { NM }\end{array}$ & $\begin{array}{c}\text { WECC- } \\
\text { CA }\end{array}$ \\
\hline Geothermal & 0.0 & 0.0 & 0.0 & 0.0 & 0.0 & 0.0 & 0.0 & 0.0 & 0.0 & 0.0 & 0.3 & 0.2 & 2.7 \\
\hline Fuel Cell & 0.0 & 0.0 & 0.0 & 0.0 & 0.0 & 0.0 & 0.0 & 0.0 & 0.0 & 0.0 & 0.0 & 0.0 & 0.0 \\
\hline Hydro & 1.4 & 0.6 & 1.2 & 0.8 & 3.2 & 4.6 & 1.7 & 0.1 & 12.1 & 2.2 & 33.7 & 5.3 & 9.8 \\
\hline Pump Stor & 2.2 & 0.0 & 1.8 & 0.4 & 0.0 & 1.2 & 1.5 & 0.0 & 7.5 & 0.5 & 0.3 & 0.7 & 3.4 \\
\hline Totals & 144.5 & 96.6 & 80.9 & 82.1 & 42.1 & 44.2 & 38.6 & 66.2 & 256.8 & 63.4 & 66.7 & 73.6 & 73.4 \\
\hline
\end{tabular}

By 2030, some plants have been retired, but additional plants have been constructed. Table 9 shows the amounts in 2030 . Note that for this study we did not add any plant capacity to meet the needs of the PHEVs. This causes some capacity constraints in certain regions, especially with the $6 \mathrm{~kW}$ evening scenarios and in 2030.

Table 9. Power plant supply by region in 2030 (GW)

\begin{tabular}{|c|c|c|c|c|c|c|c|c|c|c|c|c|c|}
\hline & ECAR & ERCOT & MAAC & MAIN & MAPP & $\begin{array}{c}\text { NPCC- } \\
\text { NY }\end{array}$ & $\begin{array}{c}\text { NPCC- } \\
\text { NE }\end{array}$ & FRCC & SERC & SPP & $\begin{array}{c}\text { WECC- } \\
\text { NW }\end{array}$ & $\begin{array}{c}\text { WECC- } \\
\text { RMP/A } \\
\text { NM }\end{array}$ & $\begin{array}{c}\text { WECC- } \\
\text { CA }\end{array}$ \\
\hline Coal Unscrub & 58.7 & 6.0 & 14.9 & 29.7 & 10.7 & 2.0 & 2.2 & 2.7 & 49.6 & 13.9 & 2.6 & 4.2 & 0.0 \\
\hline Coal Scrub & 31.0 & 22.2 & 21.2 & 5.9 & 11.4 & 4.7 & 1.1 & 17.9 & 67.6 & 16.2 & 18.6 & 37.8 & 21.8 \\
\hline Oil Steam & 0.7 & 0.0 & 7.2 & 0.4 & 0.3 & 8.0 & 5.9 & 6.5 & 2.1 & 2.5 & 0.0 & 0.0 & 0.2 \\
\hline Oil Turbine & 1.8 & 0.0 & 4.7 & 2.1 & 2.9 & 1.8 & 1.8 & 4.1 & 5.3 & 1.5 & 0.1 & 0.4 & 0.5 \\
\hline Oil Comb Cycle & 0.0 & 0.0 & 0.6 & 0.0 & 0.0 & 0.0 & 0.0 & 1.1 & 0.1 & 0.0 & 0.0 & 0.0 & 0.0 \\
\hline Gas Steam & 3.6 & 27.3 & 0.6 & 0.6 & 0.1 & 3.7 & 1.7 & 4.7 & 18.3 & 11.0 & 0.8 & 4.9 & 14.3 \\
\hline Gas Comb Cycle & 18.0 & 31.7 & 15.8 & 7.6 & 2.4 & 11.1 & 17.2 & 21.6 & 45.0 & 12.7 & 9.6 & 21.9 & 18.8 \\
\hline Gas Turbine & 29.8 & 12.4 & 8.0 & 23.4 & 7.9 & 3.6 & 1.8 & 13.7 & 41.2 & 7.9 & 5.2 & 6.9 & 7.0 \\
\hline Nuclear & 8.3 & 5.4 & 13.7 & 14.4 & 3.0 & 5.7 & 7.9 & 6.0 & 45.2 & 1.2 & 1.2 & 4.2 & 4.6 \\
\hline Solid Waste & 0.3 & 0.1 & 0.8 & 0.3 & 0.2 & 0.4 & 0.7 & 0.5 & 0.4 & 0.0 & 0.1 & 0.0 & 0.4 \\
\hline Biomass & 0.5 & 0.0 & 0.1 & 0.0 & 0.3 & 0.1 & 1.4 & 0.5 & 0.6 & 0.0 & 0.5 & 0.1 & 0.6 \\
\hline Distrib Gen & 0.3 & 1.7 & 2.1 & 0.9 & 0.6 & 0.0 & 0.7 & 0.9 & 1.1 & 0.1 & 1.4 & 0.3 & 1.2 \\
\hline Other & 0.2 & 2.9 & 0.4 & 0.5 & 1.9 & 0.4 & 0.1 & 0.7 & 0.3 & 1.6 & 2.4 & 0.8 & 3.9 \\
\hline Geothermal & 0.0 & 0.0 & 0.0 & 0.0 & 0.0 & 0.0 & 0.0 & 0.0 & 0.0 & 0.0 & 0.3 & 0.2 & 2.7 \\
\hline Fuel Cell & 0.0 & 0.0 & 0.0 & 0.0 & 0.0 & 0.0 & 0.0 & 0.0 & 0.0 & 0.0 & 0.0 & 0.0 & 0.0 \\
\hline Hydro & 1.4 & 0.6 & 1.2 & 0.8 & 3.2 & 4.6 & 1.7 & 0.1 & 12.1 & 2.2 & 33.7 & 5.3 & 9.8 \\
\hline Pump Stor & 2.2 & 0.0 & 1.8 & 0.4 & 0.0 & 1.2 & 1.5 & 0.0 & 7.5 & 0.5 & 0.0 & 0.7 & 3.4 \\
\hline Totals & 156.6 & 110.2 & 93.1 & 86.9 & 45.0 & 47.4 & 45.7 & 81.0 & 296.3 & 71.4 & 76.3 & 87.8 & 89.0 \\
\hline
\end{tabular}

\subsection{Dispatch Estimation}

The dispatch decisions for each region are based on variable costs, including fuel, operations, and $\mathrm{SO}_{2}$ and $\mathrm{NO}_{\mathrm{x}}$ emission credit prices, from the Annual Energy Outlook 2007 for each region (Table 10). Western regions of the country do not face $\mathrm{NO}_{\mathrm{X}}$ state-wide restrictions with a capand-trade process, and their $\mathrm{SO}_{2}$ credit prices are under a different system than the eastern states. The costs do not include renewable portfolio standards or other carbon-emissions restrictions that might be in place by that time. For each season, first, hydro-generation lowers the LDC beginning with the top-most points on the left side of the graph. This is because hydropower is energy limited and preferentially used during the most expensive peak times. Similarly, pumped storage units reduce the top-most, but also raise the bottom-most points at the right side, since the least expensive power is used to fill storage. 
Table 10. Emissions credit prices projected for each region by Annual Energy Outlook 2007 (dollars per ton)

\begin{tabular}{lrrrr}
\hline & \multicolumn{2}{c}{$\mathbf{2 0 2 0}$} & \multicolumn{2}{c}{$\mathbf{2 0 3 0}$} \\
\cline { 2 - 5 } & $\mathbf{N O}_{\mathbf{x}}$ & $\mathbf{S O}_{2}$ & $\mathbf{N O}_{\mathbf{x}}$ & $\mathbf{S O}_{2}$ \\
\hline ECAR & 2,548 & 961 & 3,307 & 970 \\
ERCOT & 0 & 336 & 0 & 339 \\
MAAC & 2,548 & 961 & 3,307 & 970 \\
MAIN & 2,548 & 961 & 3,307 & 970 \\
MAPP & 0 & 336 & 0 & 339 \\
NPCC-NY & 2,548 & 961 & 3,307 & 970 \\
NPCC-NE & 2,548 & 961 & 3,307 & 970 \\
FRCC & 2,548 & 961 & 3,307 & 970 \\
SERC & 2,548 & 961 & 3,307 & 970 \\
SPP & 0 & 336 & 0 & 339 \\
WECC-NW & 0 & 336 & 0 & 339 \\
WECC-RMP/ANM & 0 & 336 & 0 & 339 \\
WECC-CA & 0 & 336 & 0 & 339 \\
\hline
\end{tabular}

Once the LDCs are modified, the production plants are placed in order of increasing variable costs (or bid prices). Power plants that are not dispatchable are put at the bottom of the list since they are not controlled by the dispatchers. Plants fill up the area under the LDC. Some eventually meet the curve and so are only dispatched for a fraction of the season rather than $100 \%$. This continues until demand is fully met or all of the plants are dispatched, whichever comes first.

Because plants are not available $100 \%$ of the time, their production must be reduced by the amount of outage time. Ten or so of the baseload plants have their production reduced probabilistically, in that the dispatching is solved twice, with and without the plant available. The results are then convolved based on the outage rate. The number of recalculations grows exponentially with the number of plants treated probabilistically. All other plants have their capacity derated by their outage ratio, so that the total production from the plant is consistent.

If the power plants have insufficient capacity to meet demand (because of deratings or probabilistic lack of availability) then a portion of the demand curve is not met, resulting in unserved energy. To simulate this, the ORCED model calculates an unserved energy cost that is a function of the cost of the last plant and an elasticity factor. A calculation is made to determine how much the price would have to rise to reduce demand to the level of the last plant available. This price is then charged on electricity for that short period of time.

Once the power plants have been dispatched for each season, the annual totals can be calculated. Wholesale electricity prices can be set based on the variable cost and amount of time each plant is on the margin. Fuel use, emissions, and income can be calculated by amount and timing of generation by each plant.

As mentioned above, seven scenarios were run for each of the thirteen regions: a reference case and a combination of three different power levels to the PHEVs with charging beginning at evening time or night time. This works out to 91 separate scenarios, with three LDCSs for each 
scenario, meaning that 273 LDCs were calculated. Summary results from each run were collected and the difference of each PHEV scenario from its reference scenario provided the impact of each on generation amounts. 


\section{Regional Analysis}

In this section we present results for each of the 13 regions. Scenarios were run for both 2020 and 2030, creating a wealth of data. The discussion focuses first on the significant impacts of PHEVs on demand, such as the projected growth in demand for charging PHEVs and in total system demand. A previous analysis (Hadley 2007) indicates that charging on lower power levels lessens the peak and stretches the demand further into the valley of the load curve.

The first table presented in each section shows the highest demand level for each of the three seasons in each of the scenarios. Since the nighttime charging scenarios increase demand largely in the off-peak hours, it rarely has any impact on the peak demand. The table also shows the seasonal capacity available in 2020 and 2030 for the region. Summer capacity is lower than winter (and off-peak) capacity because many thermal plants (combustion turbines, especially) have lower capacities at higher temperatures. In ORCED the off-peak season uses the winter capacities, but then reduces each plant's capacity to reflect planned outages. In all seasons, forced outages will lower the amount of capacity as well, so that even with capacity levels above the peak demand, there can be some fraction of the season where the demand exceeds supply.

For the supply part, we consider changes in generation mix, possible unserved energy, prices, and emissions. Generation mixes as well as emissions are region-specific. Two figures are shown (2020 and 2030) with three graphs within each. The first graph shows the capacity for the region by technology and is based on the data in Table 8 and Table 9. The second graph shows the generation from each technology in the Base or "No PHEV" scenario. The last graph in each figure shows the added generation to supply the PHEVs for each scenario.

Most regions have gas-fired generation as the most frequent marginal producer, be it from combustion turbines (CT), combined cycle plants (CC), or steam turbines (ST). Nuclear, hydro, and wind generation do not appear in any of the marginal graphs because these technologies are never "on the margin." Nuclear plants are base load and always operated to their maximum extent. If additional nuclear plants were to be built, the other plants with higher variable costs, including coal, oil, and natural gas plants, would move higher in the dispatch order. Some may be retired. The mix of plants that are on the margin at different times would then change, but because of its low cost, nuclear would not likely become a load-following resource.

Hydro generation is limited by the amount of water available. Changes in demand might change the timing of when the water is released and generation occurs, but the total amount will not change. Wind power is available when the wind blows. Its generation would not be affected by the change in demand; instead, other plants would be used to follow demand.

Following the figures are tables showing the generation, energy, emissions, and wholesale prices. Although $\mathrm{SO}_{2}$ and $\mathrm{NO}_{\mathrm{X}}$ emissions are shown to be increasing in each region with the added generation, in reality the utilities increasing generation would reduce their emissions in other ways to compensate, or purchase emissions credits from others who reduced their emissions more than required. The analysis assumed prices for $\mathrm{SO}_{2}$ and $\mathrm{NO}_{\mathrm{X}}$ credits based on the results for each region from Annual Energy Outlook 2007. The cost of these credits monetize the emissions levels, so it is double-counting to show both an increase in emissions and a rise in cost. For this reason, the tables include a footnote recognizing that net emissions would not rise. 
The model predicts increased generation electricity prices for almost all regions regardless of the scenario investigated. The largest increase occurs for evening recharging of PHEVs at $6 \mathrm{~kW}$ because of the potential generation and transmission constraints introduced under these circumstances. If by 2030 generation capacity has expanded faster (in response to, for example, popularity of hybrids with the consumers), the price should go up less dramatically.

The average wholesale electricity prices shown are based on most regions setting the price based on the marginal producer at any given time. This simulates a real-time wholesale market for electricity, which is common in much of the country. Prices increase with PHEVs because at higher production levels, less economical plants are called upon more often. In a regulated costbased market, retail prices are calculated based on the average cost of power, so will not be as influenced by the marginal producer and will not increase as much.

The average price is found by dividing the total revenues for all plants by the total sales, as calculated by ORCED. In times of insufficient capacity (because of outages) the wholesale price is raised using an elasticity function to represent what the price would need to be to reduce demand to the level of available capacity. It does not include transmission or distribution costs nor the impact of electricity losses.

Lastly, the average cost of the electricity for the PHEVs is calculated by taking the difference in total cost between the base scenario and each scenario in turn, and dividing by the added generation due to the PHEVs. This cost includes fuel, variable operating costs, emissions credits, and the opportunity cost of unserved energy. These represent the added cost to the system because of the generation of power for PHEVs. In a well-regulated market, utilities would recover this cost from customers through rates, while in a competitive market, generators may earn more or less based on the market prices, and their profits would shrink or expand to make up the difference. This cost of electricity is used in the last table to calculate the cost of the electricity used for the PHEVs.

The last table in each section compares the fuel, emissions, and costs when using the battery for 20 miles each day for the year, versus the values for a non-plug-in hybrid vehicle or the PHEV using the gasoline engine to run to sustain the charge. If we assume that the vehicle gets 40 miles per gallon, emits 0.05 gram per mile of $\mathrm{NO}_{\mathrm{X}}$, with a cost of $\$ 3 /$ gallon, then a million vehicles in a region would consume 4.3 million barrels of gasoline at a cost of $\$ 548$ million, and emit 1.8 million tons of $\mathrm{CO}_{2}$ and 400 thousand tons of $\mathrm{NO}_{\mathrm{X}}$. The table only shows the results for the $2 \mathrm{~kW}$ charging scenarios. These two are similar to the results for the $1.4 \mathrm{~kW}$ charging scenario, and the results are not as influenced by the unserved energy in the $6 \mathrm{~kW}$ evening scenario. The cost of the PHEV is the added cost of fuel and other variable operating costs for the electricity used, and not the price that customers would necessarily pay for the electricity

The assumption of the fuel efficiency is a key factor; the PHEV fleet we are postulating is made up of $30 \%$ compacts, $30 \%$ mid-size sedans, $20 \%$ mid-size SUVs, and $20 \%$ full-size SUVs. While current compact HEVs (e.g., the Toyota Prius) can get between 45 and $55 \mathrm{mpg}$, larger vehicles will get less. On the other hand, technological improvements through the years between now and 2020 or 2030 should bring some improvement across the fleet. Any comparison should be between an appropriate alternative; these vehicles' market is the high-efficiency niche, $25 \%$ of 
the total sales, and not the average of the entire fleet. There is no definitive value to use for the fuel efficiency of this group.

\subsection{East Central Area Reliability Coordination Agreement (ECAR)}

Demand is usually the highest in summer and winter; therefore, addition of PHEVs to the fleet of vehicles may have the most dramatic effects in these two seasons. When generation plants operate closer to their full capacity, it is crucially important to be aware of potential adverse effects of any changes in demand associated with PHEVs' market penetration.

Table 11 shows the available capacity and peak demand in each season for each of the scenarios studied. For the night charging scenarios the model results suggest that there should be sufficient capacity available to satisfy additional demand. Peak demands do not rise except in the winter and off-peak seasons with $6 \mathrm{~kW}$ charging. The evening scenarios have a large impact, though. All seasons see a rise in the peak, with the summer peak rising from $131.2 \mathrm{GW}$ to $150.5 \mathrm{GW}$, a $15 \%$ increase.

Table 11. Capacity and peak demand in each season under each charging scenario for 2020 and 2030 in $\operatorname{ECAR}(\mathrm{GW})$

\begin{tabular}{|c|c|c|c|c|c|c|c|c|}
\hline & Capacity & $\begin{array}{c}\text { No } \\
\text { charging }\end{array}$ & $\begin{array}{c}1.4 \mathrm{~kW} \\
\text { night }\end{array}$ & $\begin{array}{l}2 \mathrm{~kW} \\
\text { night }\end{array}$ & $\begin{array}{l}6 \mathrm{~kW} \\
\text { night }\end{array}$ & $\begin{array}{c}1.4 \mathrm{~kW} \\
\text { evening }\end{array}$ & $\begin{array}{c}2 \mathrm{~kW} \\
\text { evening }\end{array}$ & $\begin{array}{c}6 \mathrm{~kW} \\
\text { evening }\end{array}$ \\
\hline \multicolumn{9}{|l|}{2020} \\
\hline Summer & 132 & 123.5 & 123.5 & 123.5 & 123.5 & 123.5 & 123.9 & 128.8 \\
\hline Winter & 137 & 104.4 & 104.4 & 104.4 & 104.6 & 107.1 & 108.6 & 113.2 \\
\hline Off-peak & 137 & 96.2 & 96.2 & 96.2 & 96.2 & 99.2 & 100.7 & 103.6 \\
\hline \multicolumn{9}{|l|}{2030} \\
\hline Summer & 145 & 131.2 & 131.2 & 131.2 & 131.2 & 134.5 & 138.3 & 150.5 \\
\hline Winter & 149 & 110.3 & 110.3 & 110.3 & 120.3 & 118.2 & 122.0 & 134.0 \\
\hline Off-peak & 149 & 101.9 & 101.9 & 101.9 & 110.1 & 110.2 & 114.0 & 123.9 \\
\hline
\end{tabular}

Figure 14 and Figure 15 show the region's generation capacity by plant type in gigawatts, the non-PHEV scenario's total generation in terawatt-hours, and the added generation for each of the PHEV scenarios. The region's electricity capacity in 2020 and 2030 is based largely on coal, with generation even more heavily coal based, followed by gas combined cycle and nuclear sources. Introduction of PHEVs into the market increases coal and gas-based electricity generation. For the night charging scenarios the greatest increase is in coal plants, while for the evening scenarios, combustion turbine plants expand their generation significantly. The model projects that with a high proportion of the PHEV fleet charging at high power in the evening, capacity may be slightly insufficient and a small amount of demand unserved. 


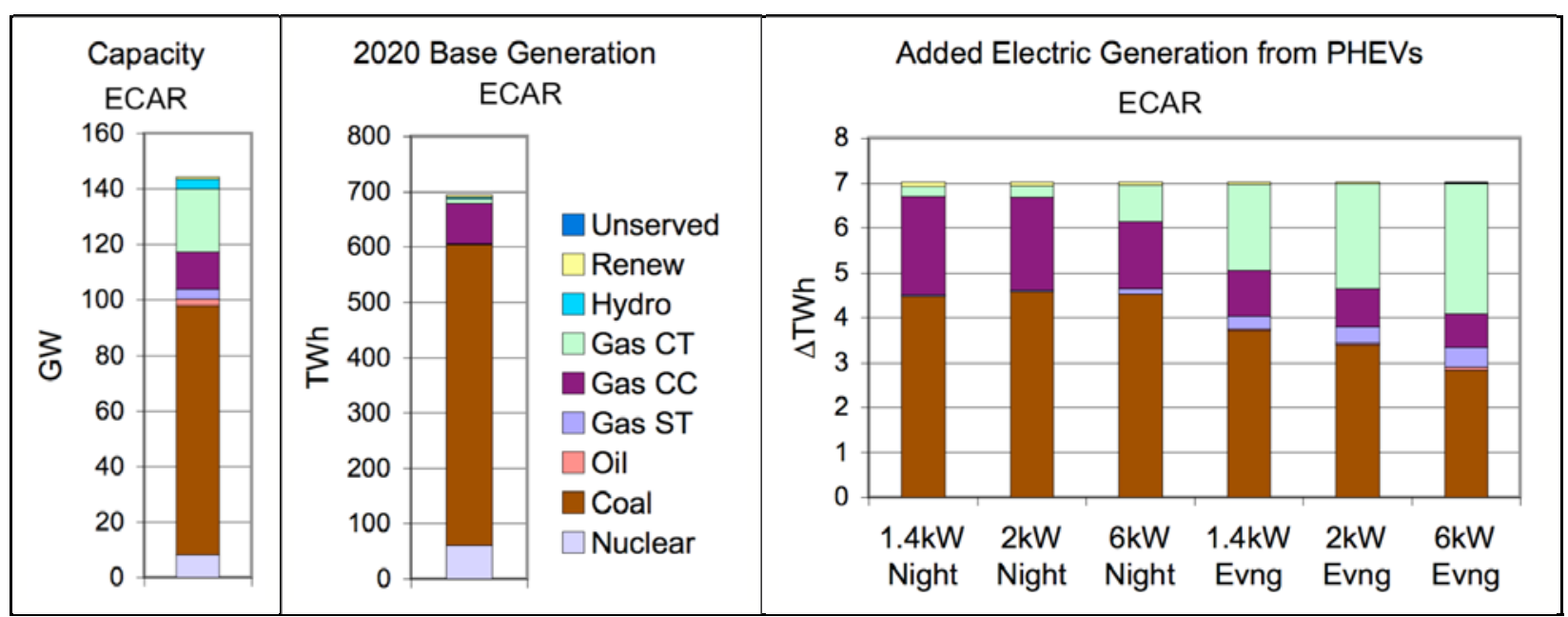

Figure 14. Projected 2020 generating capacity (left), base generation (center), and new generation dispatched to meet demand for each PHEV recharging scenario (right) for ECAR.

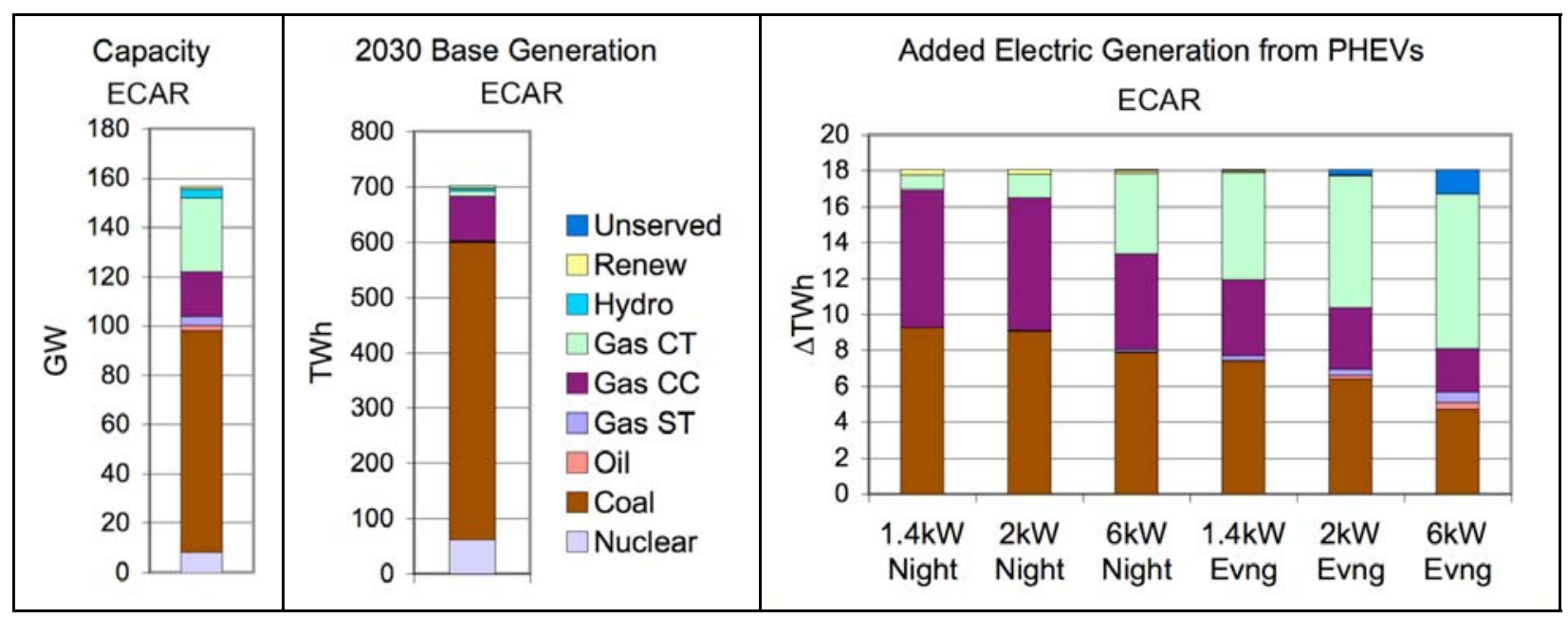

Figure 15. Projected 2030 generating capacity (left), base generation (center), and new generation dispatched to meet demand for each PHEV recharging scenario (right) for ECAR.

Table 12 presents the generation, emissions, and electricity prices for all scenarios considered. Introduction of PHEVs into the market requires increased energy output, which drives prices up in the competitive market. Since the ECAR generation mix is predominantly based on fossil fuels, more generation translates into higher emissions level for all pollutants taken into account by the model, which assumes no regulations or caps on carbon emissions in the region. The costs include the purchase of emission credits for the $\mathrm{NO}_{\mathrm{X}}$ and $\mathrm{SO}_{2}$ emissions at prices from Table 10, which would come from producers reducing their emissions an equivalent amount. 
Table 12. Generation, primary energy in, emissions, electricity prices, and PHEV charging costs in 2020 and 2030 for ECAR. Numbers in parentheses are percent change from no charging ("None").

\begin{tabular}{|c|c|c|c|c|c|c|c|c|c|c|c|c|c|}
\hline & None & \multicolumn{2}{|c|}{$\begin{array}{c}1.4 \mathrm{~kW} \\
\text { night }\end{array}$} & \multicolumn{2}{|c|}{$\begin{array}{l}2 \mathrm{~kW} \\
\text { night }\end{array}$} & \multicolumn{2}{|c|}{$\begin{array}{l}6 \mathrm{~kW} \\
\text { night }\end{array}$} & \multicolumn{2}{|c|}{$\begin{array}{c}1.4 \mathrm{~kW} \\
\text { evening }\end{array}$} & \multicolumn{2}{|c|}{$\begin{array}{c}2 \mathrm{~kW} \\
\text { evening }\end{array}$} & \multicolumn{2}{|c|}{$\begin{array}{c}6 \mathrm{~kW} \\
\text { evening }\end{array}$} \\
\hline \multicolumn{14}{|l|}{2020} \\
\hline Generation (TWh) & 695 & 702 & $(1.0)$ & 702 & $(1.0)$ & 702 & $(1.0)$ & 702 & $(1.0)$ & 702 & $(1.0)$ & 702 & (1.0) \\
\hline Unserved energy ( $T$ & 0.0 & 0.0 & & 0.0 & & 0.0 & & 0.0 & & 0.0 & & 0.0 & \\
\hline Energy in (Quads) & 6.94 & 7.01 & $(1.0)$ & 7.01 & $(1.0)$ & 7.01 & $(1.0)$ & 7.01 & (1.1) & 7.01 & (1.1) & 7.02 & (1.1) \\
\hline $\mathrm{CO}_{2}$ (MTon) & 621 & 627 & (1.0) & 627 & $(1.0)$ & 627 & $(1.0)$ & 627 & $(1.0)$ & 627 & $(1.0)$ & 627 & $(1.0)$ \\
\hline${ }^{a} \mathrm{NO}_{\mathrm{x}}$ (kTon) & 532 & 541 & (1.6) & 541 & (1.7) & 542 & (1.9) & 542 & $(1.8)$ & 542 & (1.7) & 541 & (1.6) \\
\hline${ }^{\mathrm{a}} \mathrm{SO}_{2}$ (MTon) & 3.41 & 3.47 & (1.9) & 3.48 & (2.1) & 3.48 & $(2.2)$ & 3.47 & $(1.8)$ & 3.47 & (1.7) & 3.46 & (1.5) \\
\hline Avg wholsle $p$ & 4.82 & 4.85 & (0.6) & 4.85 & $(0.7)$ & 4.88 & (1.3) & 4.92 & (2.1) & 4.93 & (2.4) & 5.03 & (4.3) \\
\hline Marg PHEV cost & 0 & 4.17 & & 4.25 & & 4.59 & & 5.10 & & 5.35 & & 5.89 & \\
\hline \multicolumn{14}{|l|}{2030} \\
\hline Generation ( & 703 & 721 & (2.6) & 721 & & 721 & ) & 721 & $(2.0)$ & 721 & 2.5) & 720 & (2.4) \\
\hline Unserved e & 0.0 & 0.0 & & 0.0 & & 0.1 & & 0.1 & & 0.3 & & 1.3 & \\
\hline Energy in (Quads) & 6.95 & 7.12 & (2.3) & 7.12 & $(2.3)$ & 7.12 & (2.4) & 7.13 & $(2.5)$ & 7.13 & (2.5) & 7.13 & (2.5) \\
\hline $\mathrm{CO}_{2}$ (MTon) & 619 & 633 & (2.2) & 633 & $(2.2)$ & 633 & (2.2) & 633 & (2.2) & 632 & (2.2) & 632 & (2.1) \\
\hline${ }^{a} \mathrm{NO}_{\mathrm{x}}$ (kTon) & 522 & 540 & (3.4) & 540 & (3.5) & 542 & (3.7) & 542 & (3.8) & 541 & (3.7) & 539 & (3.3) \\
\hline${ }^{\mathrm{a}} \mathrm{SO}_{2}$ (MTon) & 3.32 & 3.46 & (4.1) & 3.46 & $(4.2)$ & 3.46 & $(4.0)$ & 3.45 & (3.8) & 3.44 & (3.4) & 3.41 & (2.6) \\
\hline Avg wholsle price ( $(\mathrm{kWh})$ & 4.85 & 4.92 & $(1.3)$ & 4.93 & $(1.5)$ & 5.10 & $(5.1)$ & 5.23 & $(7.7)$ & 5.53 & 13.9) & 6.95 & $(43.1)$ \\
\hline Marg. PHEV cost (\$/kWh) & 0 & 4.22 & & 4.31 & & 5.00 & & 5.28 & & 6.31 & & 13.88 & \\
\hline
\end{tabular}

${ }^{a} \mathrm{NO}_{x}$ and $\mathrm{SO}_{2}$ emissions will be offset by reductions due to regulated caps.

Table 12 also shows the changes as percentages from the base scenario with no PHEVs. One observation is that night recharging results in smaller increases in wholesale electricity price and greater increases in emissions as compared to evening charging. The values in 2030 show more generation due to PHEVs. In addition, some unserved energy is calculated in the model because of the lack of sufficient capacity. There are large percentage increases in average prices as unserved energy increases. ORCED calculates high prices during the times of insufficient power that would cause consumers to lower their demand to the available amount.

Table 13 shows a comparison of the fuel use, emissions, and cost of using PHEVs versus clean, efficient hybrid electric vehicles (HEVs), with all vehicles going 20 miles per day and the efficient HEV getting 40 miles per gallon. Note that because of the high amount of coal use in ECAR, $\mathrm{CO}_{2}$ emissions are higher with PHEVs than with efficient HEVs. $\mathrm{NO}_{\mathrm{X}}$ and $\mathrm{SO}_{2}$ emissions are higher as well, but these will be offset by reductions elsewhere in the electric system because of legal caps on total emissions. Costs are much lower with the PHEVs. The marginal generating costs for the added PHEVs are used (the last line for each decade in Table 12). These costs represent the extra fuel and variable operating costs of the generating plants, the extra system costs to generate the electricity. These costs are less than a third of the gasoline cost. Even if customer prices are triple what is shown in Table 12, the customer would save money, and so likely would save money charging even at peak times. 
Table 13. Comparison of fuels, emissions, and costs for PHEVs using $2-\mathrm{kW}$ recharging versus gasoline-fueled HEVs in ECAR, 2020 and 2030

\begin{tabular}{|c|c|c|c|c|c|c|}
\hline & \multicolumn{3}{|c|}{2020} & \multicolumn{3}{|c|}{2030} \\
\hline & \multirow[t]{2}{*}{$\begin{array}{c}\text { Gasoline- } \\
\text { fueled HEVs }\end{array}$} & \multicolumn{2}{|c|}{$\begin{array}{l}\text { PHEVs charged } \\
\text { from grid }\end{array}$} & \multirow[t]{2}{*}{$\begin{array}{c}\text { Gasoline- } \\
\text { fueled HEVs }\end{array}$} & \multicolumn{2}{|c|}{$\begin{array}{l}\text { PHEVs charged } \\
\text { from grid }\end{array}$} \\
\hline & & $2 \mathrm{~kW}$ night & $2 \mathrm{~kW}$ evening & & $2 \mathrm{~kW}$ night & $2 \mathrm{~kW}$ evening \\
\hline Vehicles (million) & 2.44 & & & 6.27 & & \\
\hline \multicolumn{7}{|l|}{ Fuel } \\
\hline - Oil (million barrel) & 10.6 & 0.0 & 0.1 & 27.2 & 0.0 & 0.4 \\
\hline - Coal (million ton) & & 2.38 & 1.80 & & 4.71 & 3.43 \\
\hline - Nat Gas (billion cuft) & & 18 & 38 & & 63 & 102 \\
\hline CO2 ( million ton) & 4.3 & 6.1 & 6.1 & 11.1 & 13.8 & 13.6 \\
\hline${ }^{a} \mathrm{NO}_{\mathrm{x}}$ (thousand ton) & 1.0 & 8.9 & 9.3 & 2.5 & 18.0 & 19.2 \\
\hline${ }^{a} \mathrm{SO}_{2}$ (thousand ton) & 0 & 70 & 59 & & 139 & 114 \\
\hline${ }^{b}$ Cost (\$million) & 1,334 & 298 & 375 & 3,432 & 779 & 1,140 \\
\hline
\end{tabular}

${ }^{a} \mathrm{NO}_{\mathrm{x}}$ and $\mathrm{SO}_{2}$ emissions will be offset by reductions due to regulated caps.

${ }^{b}$ This comparison does not include the added vehicle cost for PHEV batteries or recharging capability, nor the full retail price of electricity.

\subsection{Electric Reliability Council of Texas (ERCOT)}

For all of the night charging scenarios, the PHEVs do not affect the overall peak. Only $6 \mathrm{~kW}$ charging has the potential to influence peak load values in the winter season, yet the ERCOT capacity is sufficient for accommodating surges in demand.

Evening recharging has a potential to drive electricity demand in 2030 up to $88 \mathrm{GW}$ for $1.4 \mathrm{~kW}$ charging, $90 \mathrm{GW}$ for $2 \mathrm{~kW}$ charging, and $97 \mathrm{GW}$ for $6 \mathrm{~kW}$ charging (Table 14). These numbers are below the regional generation capacity of $103 \mathrm{GW}$. However, the reserve margin (capacity divided by peak demand) is low enough so that forced outages could still cause significant amounts of unserved energy.

Table 14. Capacity and peak demand in each season under each charging scenario for 2020 and 2030 in ERCOT $(G W)$

\begin{tabular}{cccccc|ccc}
\hline & Capacity & $\begin{array}{c}\text { No } \\
\text { charging }\end{array}$ & $\begin{array}{c}\mathbf{1 . 4} \mathbf{~ k W} \\
\text { night }\end{array}$ & $\begin{array}{c}\mathbf{2 ~ k W} \\
\text { night }\end{array}$ & $\begin{array}{c}\mathbf{6} \mathbf{~ k W} \\
\text { night }\end{array}$ & $\begin{array}{c}\mathbf{1 . 4} \mathbf{~ k W} \\
\text { evening }\end{array}$ & $\begin{array}{c}\mathbf{2} \mathbf{k W} \\
\text { evening }\end{array}$ & $\begin{array}{c}\mathbf{6} \mathbf{k W} \\
\text { evening }\end{array}$ \\
\hline $\mathbf{2 0 2 0}$ & & & & & & & & \\
Summer & 89.8 & 76.4 & 76.4 & 76.4 & 76.4 & 76.7 & 77.1 & 79.9 \\
Winter & 92.5 & 61.0 & 61.0 & 61.0 & 61.0 & 63.0 & 63.8 & 66.4 \\
Off-peak & 92.5 & 66.1 & 66.1 & 66.1 & 66.1 & 66.9 & 67.3 & 70.1 \\
\hline $\mathbf{2 0 3 0}$ & & & & & & & & \\
Summer & 103.4 & 86.1 & 86.1 & 86.1 & 86.1 & 87.8 & 90.0 & 97.0 \\
Winter & 106.1 & 68.9 & 68.9 & 68.9 & 72.6 & 74.0 & 76.2 & 83.1 \\
Off-peak & 106.1 & 74.8 & 74.8 & 74.8 & 74.8 & 77.9 & 80.1 & 87.2 \\
\hline
\end{tabular}

Electricity capacity in ERCOT in 2020 is largely gas-fired, but by 2030 additional coal capacity is brought online (according to Annual Energy Outlook 2007). In 2020, coal-based generation is 
baseload (below the margin) and does not change (Figure 16.) But with its growth by 2030, it does move to the margin for night charging (Figure 17.) The increase in demand from PHEVs is expected to be satisfied by gas combustion turbines, gas combined cycle plants, and gas steam powered plants. Evening recharge patterns show a growth in gas steam production in 2020, but this source is exhausted in 2030, as are all supplies, and so there is significant unserved energy for the $6 \mathrm{~kW}$ evening scenario.

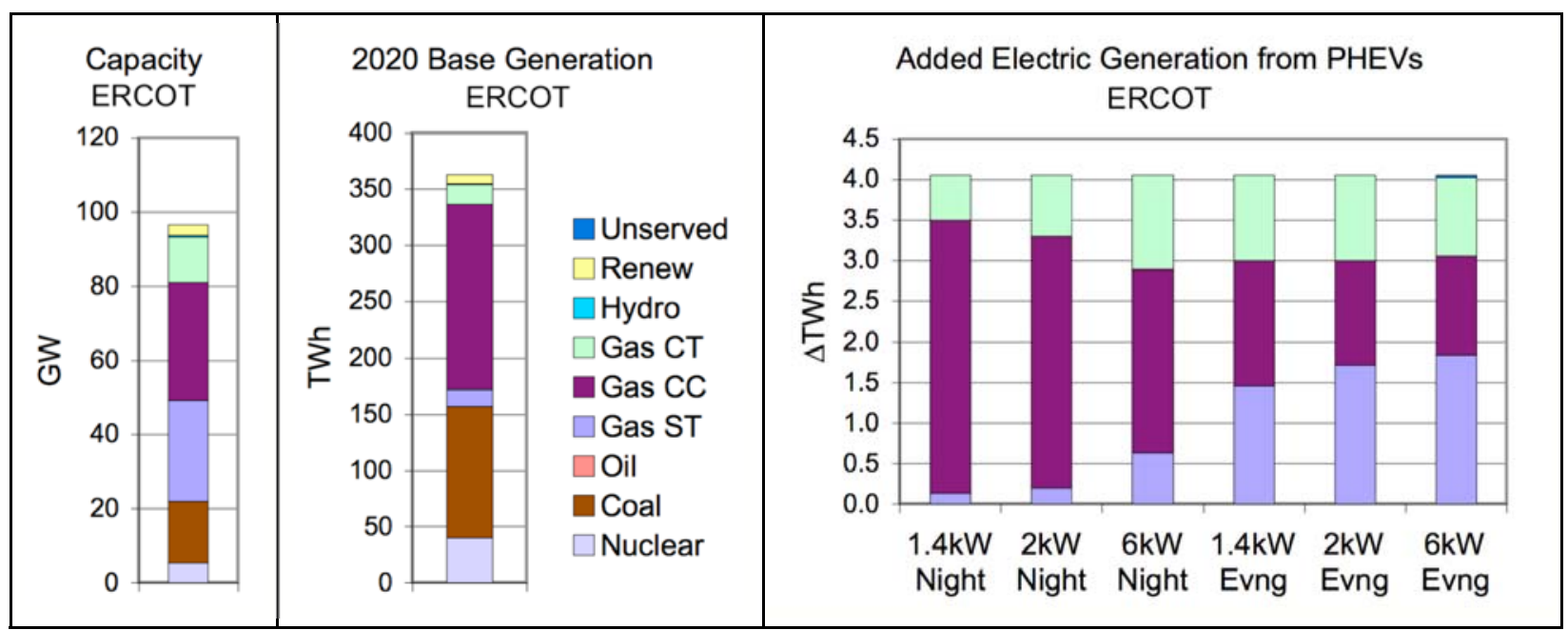

Figure 16. Projected 2020 generating capacity (left), base generation (center), and new generation dispatched to meet demand for each PHEV recharging scenario (right) for ERCOT.

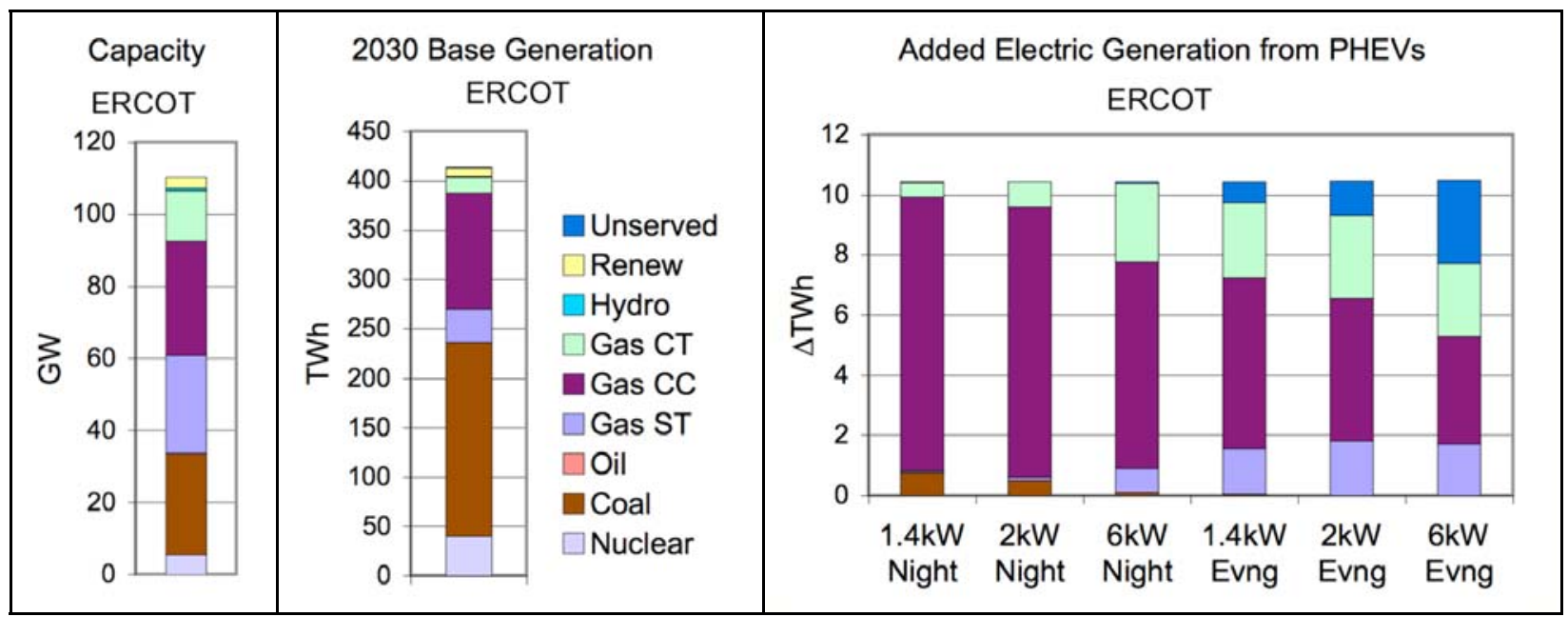

Figure 17. Projected 2030 generating capacity (left), base generation (center), and new generation dispatched to meet demand for each PHEV recharging scenario (right) for ERCOT.

Table 15 shows ERCOT's generation, price, and emissions results. Energy in and $\mathrm{CO}_{2}$ emissions stay relatively flat since natural gas is the primary fuel used. $\mathrm{NO}_{\mathrm{X}}$ emissions are higher with recharging in the evening because more electricity comes from high-emitting turbines and boilers. The region was modeled with no $\mathrm{NO}_{\mathrm{X}}$ emissions credit costs. $\mathrm{SO}_{2}$ emissions are higher for night recharging in 2030 because of the coal used. Prices accelerate most rapidly in the evening scenarios in 2030 because of the lack of capacity. Unserved energy drives up marginal costs during those times, which affects both the average price and the cost of PHEV power. 
Table 15. Generation, primary energy in, emissions, electricity prices, and PHEV charging costs in 2020 and 2030 for ERCOT. Numbers in parentheses are percent change from no charging ("None").

\begin{tabular}{|c|c|c|c|c|c|c|c|c|c|c|c|c|c|}
\hline & None & \multicolumn{2}{|c|}{$\begin{array}{c}1.4 \mathrm{~kW} \\
\text { night }\end{array}$} & \multicolumn{2}{|c|}{$\begin{array}{l}2 \mathrm{~kW} \\
\text { night }\end{array}$} & \multicolumn{2}{|c|}{$\begin{array}{l}6 \mathrm{~kW} \\
\text { night }\end{array}$} & \multicolumn{2}{|c|}{$\begin{array}{c}1.4 \mathrm{~kW} \\
\text { evening }\end{array}$} & \multicolumn{2}{|c|}{$\begin{array}{c}2 \mathrm{~kW} \\
\text { evening }\end{array}$} & \multicolumn{2}{|c|}{$\begin{array}{c}6 \mathrm{~kW} \\
\text { evening }\end{array}$} \\
\hline \multicolumn{14}{|l|}{2020} \\
\hline Generation (TWh) & 363 & 367 & $(1.1)$ & 367 & (1.1) & 367 & $(1.1)$ & 367 & (1.1) & 367 & (1.1) & 367 & (1.1) \\
\hline Unserved energy ( $T$ & & 0.0 & & 0.0 & & 0.0 & & 0.0 & & 0.0 & & 0.0 & \\
\hline Energy in (Quads) & 3.24 & 3.27 & $(1.0)$ & 3.27 & $(1.0)$ & 3.27 & $(1.0)$ & 3.28 & (1.1) & 3.28 & (1.2) & 3.28 & (1.2) \\
\hline $\mathrm{CO}_{2}$ (MTon) & 217 & 218 & $(0.8)$ & 218 & $(0.8)$ & 219 & $(0.9)$ & 219 & (1.0) & 219 & (1.0) & 219 & (1.1) \\
\hline $\mathrm{NO}_{\mathrm{x}}$ (kTon) & 169 & 170 & $(0.5)$ & 170 & $(0.6)$ & 171 & $(0.9)$ & 171 & (1.1) & 171 & (1.2) & 171 & (1.3) \\
\hline${ }^{a} \mathrm{SO}_{2}$ (kTon) & 292 & 292 & $(0.0)$ & 292 & $(0.0)$ & 292 & $(0.0)$ & 292 & $(0.0)$ & 292 & $(0.0)$ & 292 & $(0.0)$ \\
\hline Avg electr. pri & 5.49 & 5.50 & $(0.3)$ & 5.51 & $(0.4)$ & 5.53 & $(0.8)$ & 5.55 & (1.0) & 5.56 & (1.3) & 5.62 & (2.4) \\
\hline Marg PHEV cost & 0 & 4.65 & & 4.74 & & 5.13 & & 5.64 & & 5.84 & & 6.28 & \\
\hline \multicolumn{14}{|l|}{2030} \\
\hline Generation (TWh) & 410 & 424 & $(2.5)$ & 424 & $(2$. & 424 & (2.5) & 423 & (2.4) & 423 & (2.3) & 421 & (1.9) \\
\hline Unserved e & & 0.9 & & 0.9 & & 1.0 & & 1.6 & & 2.1 & & 3.7 & \\
\hline Energy in (Quads) & 3.81 & 3.89 & $(2.1)$ & 3.89 & $(2.1)$ & 3.89 & $(2.2)$ & 3.89 & (2.2) & 3.89 & (2.2) & 3.88 & (1.9) \\
\hline $\mathrm{CO}_{2}$ (MTon) & 280 & 285 & $(1.8)$ & 285 & $(1.8)$ & 285 & (1.8) & 285 & (1.8) & 285 & (1.8) & 284 & (1.5) \\
\hline $\mathrm{NO}_{x}$ (kTon) & 215 & 218 & $(1.2)$ & 217 & $(1.1)$ & 218 & $(1.4)$ & 219 & (1.8) & 219 & (2.0) & 219 & (1.9) \\
\hline${ }^{a} \mathrm{SO}_{2}$ (kTon) & 269 & 272 & $(0.9)$ & 271 & $(0.6)$ & 270 & $(0.2)$ & 270 & $(0.1)$ & 269 & $(0.0)$ & 269 & $(0.0)$ \\
\hline Avg wholsle price ( $(\mathrm{kWh})$ & 7.77 & 7.76 & $(-0.1)$ & 7.76 & $(-0.1)$ & 7.99 & $(2.9)$ & 9.29 & (19.6) & 10.27 & (32.3) & 14.01 & $(80.4)$ \\
\hline Marg. PHEV cost (\$/kWh) & 0 & 4.60 & & 4.74 & & 5.85 & & 13.92 & & 20.83 & & 57.59 & \\
\hline
\end{tabular}

${ }^{a} \mathrm{SO}_{2}$ emissions will be offset by reductions due to regulated caps.

The comparison between the fuel use, emissions, and cost of the PHEV vehicles in the region using gasoline versus electricity for driving 20 miles per day is shown in Table 16. With gas being the main fuel used for the added generation in ERCOT, $\mathrm{CO}_{2}$ emissions are lower with PHEVs than with efficient HEVs. $\mathrm{NO}_{\mathrm{X}}$ emissions are higher, because some of the gas-fired production is from older combustion turbines or steam turbines with higher $\mathrm{NO}_{\mathrm{X}}$ emissions. $\mathrm{SO}_{2}$ emissions are higher, but these will be offset by reductions elsewhere in the electric system because of the legal caps on total emissions. Costs are much lower with the PHEVs, except the $2 \mathrm{~kW}$ evening scenario in 2030. These costs are less than a third of the gasoline cost. Even if customer prices are triple the average cost, the customer would save money, and so likely would save money charging even at peak times. The costs for the $2 \mathrm{~kW}$ evening scenario are high because of the unserved energy due to higher demand. 
Table 16. Comparison of fuels, emissions, and costs for PHEVs using $2-\mathrm{kW}$ recharging versus gasoline-fueled HEVs in ERCOT, 2020 and 2030

\begin{tabular}{|c|c|c|c|c|c|c|}
\hline & \multicolumn{3}{|c|}{2020} & \multicolumn{3}{|c|}{2030} \\
\hline & \multirow[t]{2}{*}{$\begin{array}{c}\text { Gasoline- } \\
\text { fueled HEVs }\end{array}$} & \multicolumn{2}{|c|}{$\begin{array}{l}\text { PHEVs charged } \\
\text { from grid }\end{array}$} & \multirow[t]{2}{*}{$\begin{array}{c}\text { Gasoline- } \\
\text { fueled HEVs }\end{array}$} & \multicolumn{2}{|c|}{$\begin{array}{l}\text { PHEVs charged } \\
\text { from grid }\end{array}$} \\
\hline & & 2 kW night & $2 \mathrm{~kW}$ evening & & $2 \mathrm{~kW}$ night & $2 \mathrm{~kW}$ evening \\
\hline Vehicles (million) & 1.41 & & & 3.62 & & \\
\hline \multicolumn{7}{|l|}{ Fuel } \\
\hline - Oil (million barrel) & 6.1 & 0.0 & 0.0 & 15.8 & 0.0 & 0.0 \\
\hline - Coal (million ton) & & 0.00 & 0.00 & & 0.28 & 0.0 \\
\hline - Nat Gas (billion cuft) & & 31 & 37 & & 72 & 83 \\
\hline CO2 ( million ton) & 2.5 & 1.8 & 2.2 & 6.4 & 4.9 & 4.9 \\
\hline $\mathrm{NO}_{\mathrm{x}}$ (thousand ton) & 0.6 & 1.0 & 2.1 & 1.5 & 2.3 & 4.2 \\
\hline${ }^{a} \mathrm{SO}_{2}$ (thousand ton) & 0 & 0 & 0 & & 2 & 0 \\
\hline${ }^{b}$ Cost (\$million) & 771 & 193 & 237 & 1,985 & 495 & 2,176 \\
\hline
\end{tabular}

${ }^{a} \mathrm{SO}_{2}$ emissions will be offset by reductions due to regulated caps.

${ }^{b}$ This comparison does not include the added vehicle cost for PHEV batteries or recharging capability, nor the full retail price of electricity.

\subsection{Mid-Atlantic Area Council (MAAC)}

The peak demand patterns of the previously analyzed regions are repeated here. The night scenarios have no impact on the peak loads, except the $6 \mathrm{~kW}$ scenario in 2030 (Table 17). Evening charging has an increasing impact at the higher power levels. If PHEVs recharge during the night it partially fills the valleys of the load curves, not affecting the peak load values. In the case of evening charging, peak loads go up. Summer peaks approach or exceed the summer capacity, causing unserved energy at the higher power levels.

Table 17. Capacity and peak demand in each season under each charging scenario for 2020 and 2030 in MAAC (GW)

\begin{tabular}{cccccc|ccc}
\hline & Capacity & $\begin{array}{c}\text { No } \\
\text { charging }\end{array}$ & $\begin{array}{c}\mathbf{1 . 4} \mathbf{~ k W} \\
\text { night }\end{array}$ & $\begin{array}{c}\mathbf{2 ~ k W} \\
\text { night }\end{array}$ & $\begin{array}{c}\mathbf{6} \mathbf{~ k W} \\
\text { night }\end{array}$ & $\begin{array}{c}\mathbf{1 . 4} \mathbf{~ k W} \\
\text { evening }\end{array}$ & $\begin{array}{c}\mathbf{2} \mathbf{k W} \\
\text { evening }\end{array}$ & $\begin{array}{c}\mathbf{6} \mathbf{~ k W} \\
\text { evening }\end{array}$ \\
\hline $\mathbf{2 0 2 0}$ & & & & & & & & \\
Summer & 75.4 & 70.8 & 70.8 & 70.8 & 70.8 & 71.0 & 71.7 & 75.1 \\
Winter & 79.3 & 55.8 & 55.8 & 55.8 & 55.8 & 58.3 & 59.4 & 62.8 \\
Off-peak & 79.3 & 51.2 & 51.2 & 51.2 & 51.2 & 53.7 & 54.8 & 57.6 \\
\hline $\mathbf{2 0 3 0}$ & & & & & & & & \\
Summer & 86.5 & 79.2 & 79.2 & 79.2 & 80.0 & 82.9 & 85.6 & 94.5 \\
Winter & 90.3 & 62.4 & 62.4 & 62.4 & 70.0 & 68.8 & 71.5 & 80.4 \\
Off-peak & 90.3 & 57.3 & 57.3 & 57.3 & 65.6 & 63.6 & 66.4 & 74.7 \\
\hline
\end{tabular}

The generation mix in the Mid-Atlantic Area Council area is dominated by coal, with nuclear power being the second and gas the third largest source (Figure 18 and Figure 19). The changes in demand caused by introduction of PHEVs are likely to be satisfied differently for night and evening recharging. Gas-fired combined cycle plays a large role in all scenarios. Night charging calls upon coal plants for the rest of the power, but evening charging calls for more gas-fired 
combustion turbines and oil-fired capacity (turbines, combined cycle, and steam boilers). The oil share keeps growing as the battery power level increases in the evening recharge scenarios, which decreases the reduction in oil use from replacing conventional vehicles with PHEVs.

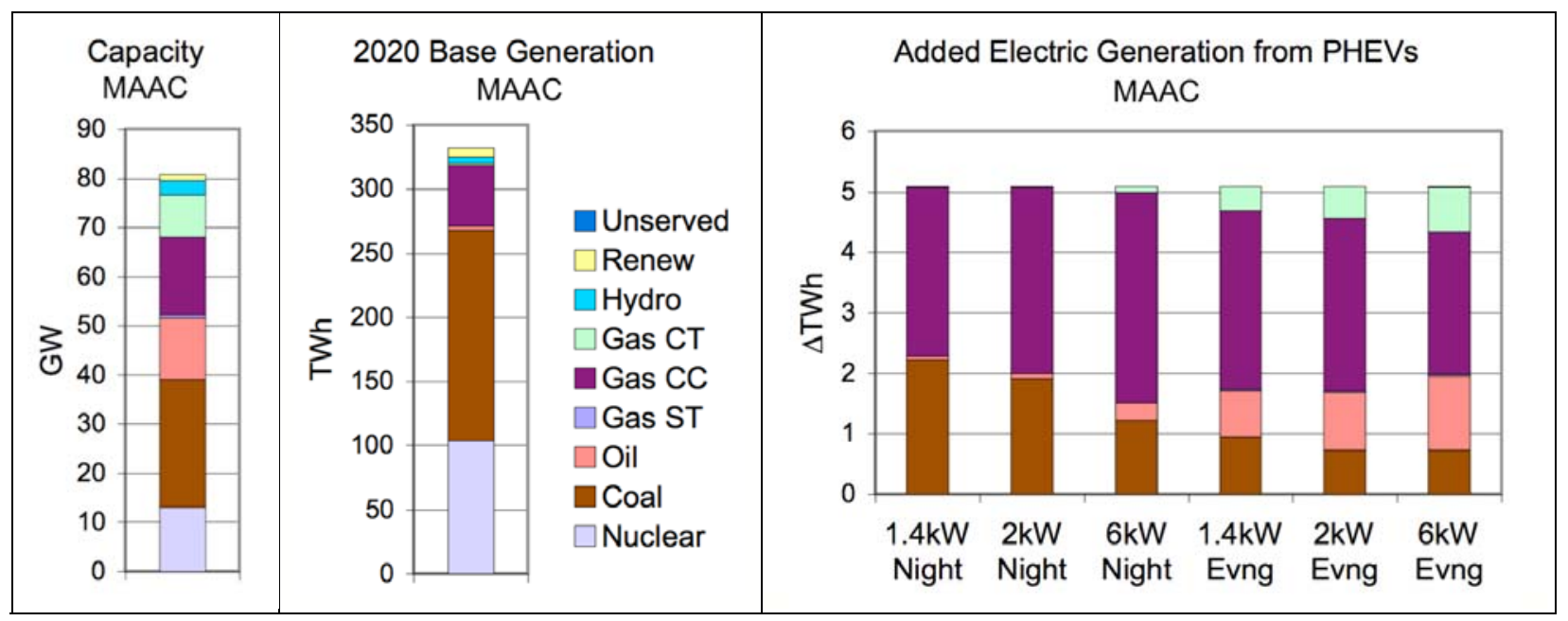

Figure 18. Projected 2020 generating capacity (left), base generation (center), and new generation dispatched to meet demand for each PHEV recharging scenario (right) for MAAC.

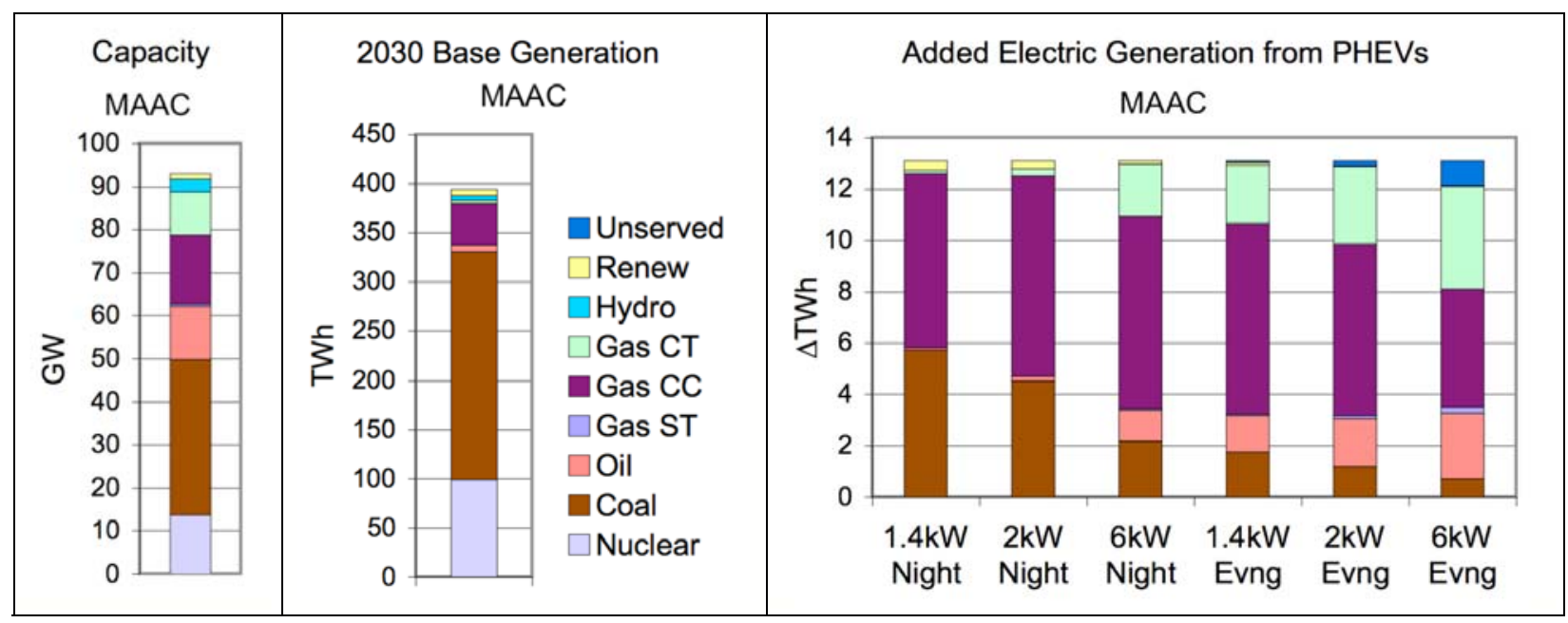

Figure 19. Projected 2030 generating capacity (left), base generation (center), and new generation dispatched to meet demand for each PHEV recharging scenario (right) for MAAC.

Renewable power, in this case municipal solid waste plants, do provide a small amount of added production at night in 2030. These plants might not be fully loaded and have about the same variable cost as some coal plants, so are not fully loaded until the PHEVs are added.

As in the previous cases, change in demand caused by $2 \mathrm{~kW}$ and especially the $6 \mathrm{k} \mathrm{W}$ charging in the evenings has to be served by some other means, possibly imports or expansion of the generation capacity beyond the currently planned level.

Table 18 presents statistics for the generation, price, and emissions in 2020 and 2030 and their changes due to the increased number of PHEVs. Overall, the numbers for the MAAC area are not very sensitive to the scenario considered. $\mathrm{NO}_{\mathrm{X}}$ emissions tend to increase and $\mathrm{SO}_{2}$ emissions 
decrease as more power is generated in the evening. The electricity price is most sensitive to the recharging pattern, increasing by $1.7 \%$ for $1.4 \mathrm{~kW}$ charging at night and by $68 \%$ for the $6 \mathrm{~kW}$ charging in the evenings in 2030.

Table 18. Generation, primary energy in, emissions, electricity prices, and PHEV charging costs in 2020 and 2030 for MAAC. Numbers in parentheses are percent change from no charging ("None").

\begin{tabular}{|c|c|c|c|c|c|c|c|c|c|c|c|c|c|}
\hline & None & \multicolumn{2}{|c|}{$\begin{array}{c}1.4 \mathrm{~kW} \\
\text { night }\end{array}$} & \multicolumn{2}{|c|}{$\begin{array}{l}2 \mathrm{~kW} \\
\text { night }\end{array}$} & \multicolumn{2}{|c|}{$\begin{array}{l}6 \mathrm{~kW} \\
\text { night }\end{array}$} & \multicolumn{2}{|c|}{$\begin{array}{c}1.4 \mathrm{~kW} \\
\text { evening }\end{array}$} & \multicolumn{2}{|c|}{$\begin{array}{c}2 \text { kW } \\
\text { evening }\end{array}$} & \multicolumn{2}{|c|}{$\begin{array}{c}6 \mathrm{~kW} \\
\text { evening }\end{array}$} \\
\hline Generation (TWh) & 332 & 337 & (1.5) & 337 & $(1.5)$ & 337 & $(1.5)$ & 337 & (1.5) & 337 & (1.5) & 337 & (1.5) \\
\hline Unserved energy (TWh) & 0.0 & 0.0 & & 0.0 & & 0.0 & & 0.0 & & 0.0 & & 0.0 & \\
\hline Energy in (Quads) & 3.25 & 3.30 & (1.3) & 3.30 & (1.3) & 3.30 & (1.3) & 3.30 & (1.4) & 3.30 & (1.4) & 3.30 & (1.5) \\
\hline $\mathrm{CO}_{2}$ (MTon) & 196 & 200 & (1.8) & 200 & $(1.7)$ & 199 & $(1.6)$ & 200 & (1.7) & 200 & (1.7) & 200 & (1.9) \\
\hline${ }^{a} \mathrm{NO}_{x}$ (kTon) & 164 & 167 & $(1.8)$ & 167 & $(1.7)$ & 167 & $(2.0)$ & 168 & (2.4) & 168 & (2.5) & 169 & (2.9) \\
\hline${ }^{a} \mathrm{SO}_{2}$ (kTon) & 1,263 & 1,298 & (2.8) & 1,294 & $(2.4)$ & 1,285 & $(1.7)$ & 1,283 & (1.6) & 1,280 & (1.4) & 1,281 & (1.5) \\
\hline Avg wholsle pr & 4.95 & 4.97 & $(0.5)$ & 4.97 & $(0.5)$ & 5.00 & $(1.0)$ & 5.06 & (2.3) & 5.09 & (2.9) & 5.22 & (5.5) \\
\hline Marg PHEV cost ( $\$ / k W h)$ & 0 & 4.30 & & 4.23 & & 4.46 & & 5.10 & & 5.36 & & 6.08 & \\
\hline \multicolumn{14}{|l|}{2030} \\
\hline Generation (TWh) & 394 & 408 & (3.3) & 408 & $(3.3)$ & 408 & (3.3) & 408 & (3.3) & 407 & (3.3) & 407 & (3.1) \\
\hline Unserved energy (TWh) & 0.0 & 0.0 & & 0.0 & & 0.0 & & 0.1 & & 0.2 & & 1.0 & \\
\hline Energy in (Quads) & 3.79 & 3.90 & (3.1) & 3.90 & $(3.0)$ & 3.91 & (3.2) & 3.91 & (3.2) & 3.91 & (3.3) & 3.92 & (3.4) \\
\hline $\mathrm{CO}_{2}$ (MTon) & 258 & 267 & (3.5) & 267 & (3.3) & 267 & (3.2) & 267 & (3.2) & 267 & (3.3) & 267 & (3.4) \\
\hline${ }^{a} \mathrm{NO}_{x}$ (kTon) & 196 & 203 & (3.6) & 203 & (3.5) & 204 & $(4.2)$ & 205 & (4.4) & 205 & (4.7) & 206 & $(5.1)$ \\
\hline${ }^{a} \mathrm{SO}_{2}$ (kTon) & 1,260 & 1,349 & $(7.1)$ & 1,332 & $(5.7)$ & 1,301 & (3.3) & 1,295 & (2.8) & 1,288 & (2.3) & 1,281 & $(1.7)$ \\
\hline Avg wholsle price (\$/kWh) & 5.43 & 5.52 & $(1.7)$ & 5.54 & $(2.1)$ & 5.81 & $(7.1)$ & 6.03 & 11.1) & 6.40 & $(18.0)$ & 8.69 & $(60.2)$ \\
\hline Marg. PHEV cost ( $\$ / k W h)$ & 0 & 4.61 & & 4.74 & & 5.71 & & 6.27 & & 7.57 & & 21.43 & \\
\hline
\end{tabular}

${ }^{a} \mathrm{NO}_{\mathrm{x}}$ and $\mathrm{SO}_{2}$ emissions will be offset by reductions due to regulated caps.

The comparison between the fuel use, emissions, and cost for the PHEV vehicles in the region using gasoline versus electricity for the 20 miles per day is shown in Table 19. Note that because of the high amount of coal and oil used for PHEV generation in MAAC (Figure 18), $\mathrm{CO}_{2}$ emissions are higher with PHEVs than with efficient $\mathrm{HEVs}$. $\mathrm{NO}_{\mathrm{X}}$ and $\mathrm{SO}_{2}$ emissions are higher as well, but these will be offset by reductions elsewhere in the electric system because of legal caps on total emissions. Costs are much lower with the PHEVs, less than a third of the gasoline cost. Even if customer prices are triple from what is shown in Table 18 the customer would save money, and so likely would save money charging even at peak times. 
Table 19. Comparison of fuels, emissions, and costs for PHEVs using $2-\mathrm{kW}$ recharging versus gasoline-fueled HEVs in MAAC, 2020 and 2030

\begin{tabular}{|c|c|c|c|c|c|c|}
\hline & \multicolumn{3}{|c|}{2020} & \multicolumn{3}{|c|}{2030} \\
\hline & \multirow[t]{2}{*}{$\begin{array}{c}\text { Gasoline- } \\
\text { fueled HEVs }\end{array}$} & \multicolumn{2}{|c|}{$\begin{array}{l}\text { PHEVs charged } \\
\text { from grid }\end{array}$} & \multirow[t]{2}{*}{$\begin{array}{c}\text { Gasoline- } \\
\text { fueled HEVs }\end{array}$} & \multicolumn{2}{|c|}{$\begin{array}{l}\text { PHEVs charged } \\
\text { from grid }\end{array}$} \\
\hline & & 2 kW night & $2 \mathrm{~kW}$ evening & & $2 \mathrm{~kW}$ night & $2 \mathrm{~kW}$ evening \\
\hline Vehicles (million) & 1.77 & & & 4.54 & & \\
\hline \multicolumn{7}{|l|}{ Fuel } \\
\hline - Oil (million barrel) & 7.7 & 0.1 & 2.1 & 19.7 & 0.4 & 4.3 \\
\hline - Coal (million ton) & & 0.96 & 0.39 & & 2.25 & 0.66 \\
\hline - Nat Gas (billion cuft) & & 22 & 28 & & 59 & 87 \\
\hline CO2 ( million ton) & 3.1 & 3.4 & 3.4 & 8.0 & 8.5 & 8.5 \\
\hline${ }^{a} \mathrm{NO}_{\mathrm{x}}$ (thousand ton) & 0.7 & 2.8 & 4.2 & 1.8 & 6.9 & 9.3 \\
\hline${ }^{a} \mathrm{SO}_{2}$ (thousand ton) & 0 & 31 & 17 & & 72 & 29 \\
\hline${ }^{b}$ Cost (\$million) & 967 & 215 & 273 & 2,488 & 621 & 992 \\
\hline
\end{tabular}

${ }^{a} \mathrm{NO}_{\mathrm{x}}$ and $\mathrm{SO}_{2}$ emissions will be offset by reductions due to regulated caps.

${ }^{b}$ This comparison does not include the added vehicle cost for PHEV batteries or recharging capability, nor the full retail price of electricity.

\subsection{Mid-America Interconnected Network (MAIN)}

In 2020, the night recharging patterns do not significantly change the peaks, and even the evening charging scenarios do not approach the local generation capacity (Table 20.) In the 2030 scenarios, however, summer peaks approach and exceed the region's capacity, meaning that additional capacity would need to be built for the PHEV demand or sales to and from other regions would have to change.

Table 20. Capacity and peak demand in each season under each charging scenario for 2020 and 2030 in MAIN (GW)

\begin{tabular}{|c|c|c|c|c|c|c|c|c|}
\hline & Capacity & $\begin{array}{c}\text { No } \\
\text { charging }\end{array}$ & $\begin{array}{c}1.4 \mathrm{~kW} \\
\text { night }\end{array}$ & $\begin{array}{l}2 \mathrm{~kW} \\
\text { night }\end{array}$ & $\begin{array}{l}6 \mathrm{~kW} \\
\text { night }\end{array}$ & $\begin{array}{c}1.4 \mathrm{~kW} \\
\text { evening }\end{array}$ & $\begin{array}{c}2 \mathrm{~kW} \\
\text { evening }\end{array}$ & $\begin{array}{c}6 \mathrm{~kW} \\
\text { evening }\end{array}$ \\
\hline \multicolumn{9}{|l|}{2020} \\
\hline Summer & 75.0 & 63.0 & 63.0 & 63.0 & 63.0 & 64.1 & 65.2 & 68.8 \\
\hline Winter & 78.0 & 48.6 & 48.6 & 48.6 & 52.0 & 51.2 & 52.3 & 55.9 \\
\hline Off-peak & 78.0 & 53.1 & 53.1 & 53.1 & 53.1 & 54.3 & 55.4 & 59.0 \\
\hline \multicolumn{9}{|l|}{2030} \\
\hline Summer & 79.8 & 69.6 & 69.6 & 69.6 & 74.1 & 73.7 & 76.5 & 85.7 \\
\hline Winter & 82.9 & 53.8 & 53.8 & 54.1 & 63.3 & 60.5 & 63.3 & 72.5 \\
\hline Off-peak & 82.9 & 58.5 & 58.5 & 58.5 & 62.1 & 63.0 & 65.9 & 75.0 \\
\hline
\end{tabular}

The MAIN generation mix is primarily based on coal, nuclear power, and gas (Figure 20 and Figure 21). The increased demand due to the PHEVs is expected to be satisfied predominantly by gas combustion turbines and coal. The coal share is different for night and evening recharging; it is higher if PHEVs are charged at night. As charging power level goes up, the generation mix shifts to a more gas-intensive one. The generation capacity expected to be in place by 2030 may not be able to cover the increased demand completely for the $6 \mathrm{~kW}$ evening charging schedule. 


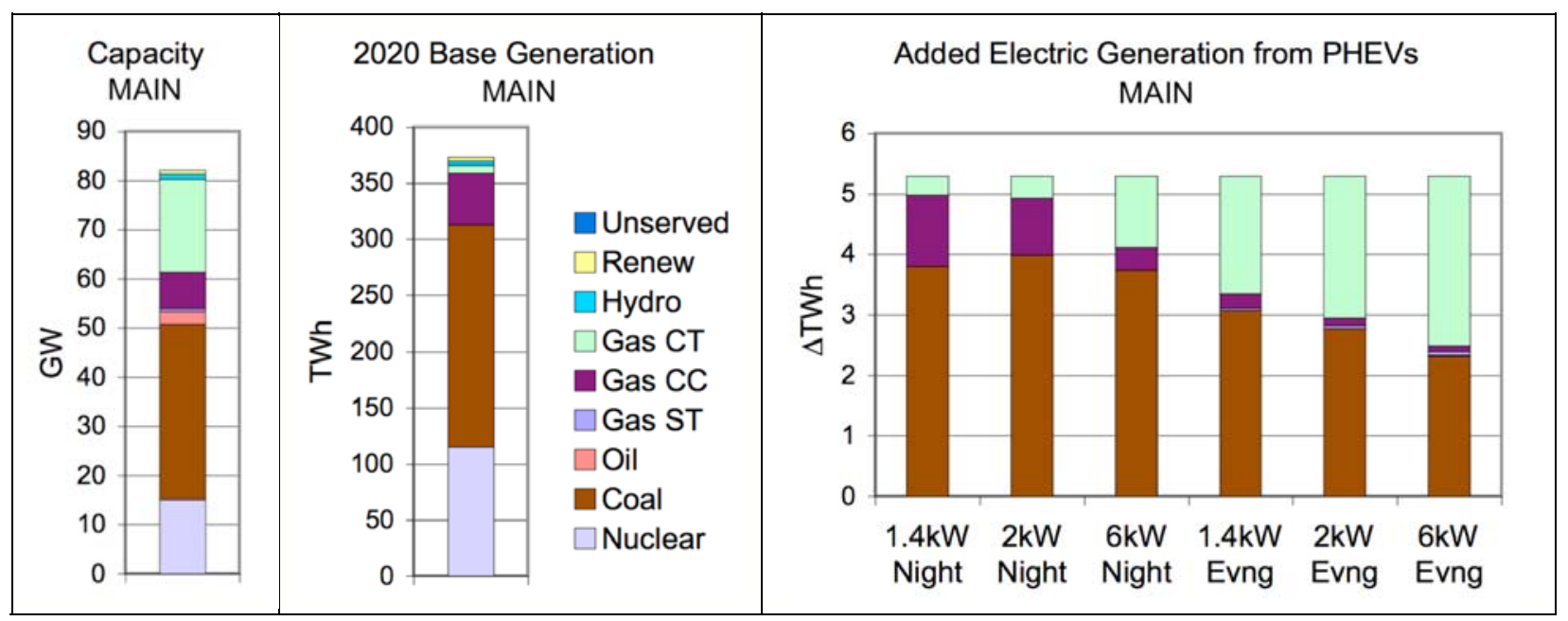

Figure 20. Projected 2020 generating capacity (left), base generation (center), and new generation dispatched to meet demand for each PHEV recharging scenario (right) for MAIN.

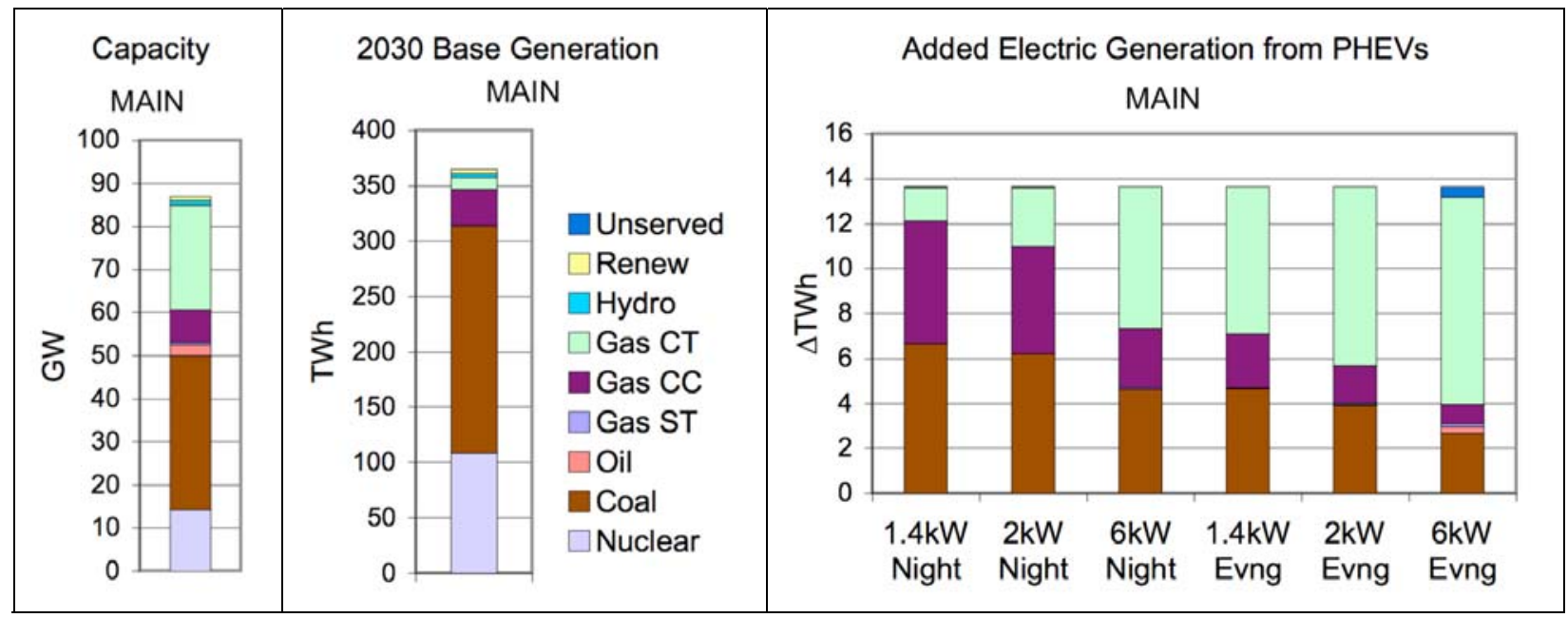

Figure 21. Projected 2030 generating capacity (left), base generation (center), and new generation dispatched to meet demand for each PHEV recharging scenario (right) for MAIN.

Introduction of PHEVs to the market is predicted to drive up generation, price, and emissions of electricity plants (Table 21). $\mathrm{SO}_{2}$ and $\mathrm{NO}_{\mathrm{X}}$ levels are sensitive to recharging scenarios considered in this study while other factors stay relatively flat through the scenarios. Evening recharging stimulates fewer $\mathrm{SO}_{2}$ emissions as compared to night recharging, but more $\mathrm{NO}_{\mathrm{x}}$ emissions because of the shift from coal generation to gas-fired combustion turbines. Price is a little more sensitive, especially in the $6 \mathrm{~kW}$ evening scenario in 2030. Price may increase as much as $42 \%$ from 4.80 to 6.69 cents per $\mathrm{kWh}$. Yet this increase is rather modest compared to some of the other regions. 
Table 21. Generation, primary energy in, emissions, electricity prices, and PHEV charging costs in 2020 and 2030 for MAIN. Numbers in parentheses are percent change from no charging ("None").

\begin{tabular}{|c|c|c|c|c|c|c|c|c|c|c|c|c|c|}
\hline & None & \multicolumn{2}{|c|}{$\begin{array}{c}1.4 \mathrm{~kW} \\
\text { night }\end{array}$} & \multicolumn{2}{|c|}{$\begin{array}{l}2 \mathrm{~kW} \\
\text { night }\end{array}$} & \multicolumn{2}{|c|}{$\begin{array}{l}6 \mathrm{~kW} \\
\text { night }\end{array}$} & \multicolumn{2}{|c|}{$\begin{array}{c}1.4 \mathrm{~kW} \\
\text { evening }\end{array}$} & \multicolumn{2}{|c|}{$\begin{array}{c}2 \mathrm{~kW} \\
\text { evening }\end{array}$} & \multicolumn{2}{|c|}{$\begin{array}{c}6 \mathrm{~kW} \\
\text { evening }\end{array}$} \\
\hline \multicolumn{14}{|l|}{2020} \\
\hline Generation (TWh) & 373 & 378 & (1.4) & 378 & (1.4) & 378 & $(1.4)$ & 378 & $(1.4)$ & 378 & $(1.4)$ & 378 & $(1.4)$ \\
\hline Unserved energy (TWh) & 0.0 & 0.0 & & 0.0 & & 0.0 & & 0.0 & & 0.0 & & 0.0 & \\
\hline Energy in (Quads) & 3.69 & 3.74 & $(1.4)$ & 3.75 & $(1.4)$ & 3.75 & $(1.5)$ & 3.75 & $(1.5)$ & 3.75 & $(1.6)$ & 3.75 & (1.6) \\
\hline $\mathrm{CO}_{2}$ (MTon) & 237 & 242 & $(2.1)$ & 242 & $(2.1)$ & 242 & $(2.2)$ & 242 & $(2.1)$ & 242 & $(2.0)$ & 242 & $(2.0)$ \\
\hline${ }^{a} \mathrm{NO}_{x}(\mathrm{kTon})$ & 219 & 224 & (2.3) & 224 & (2.6) & 226 & (3.2) & 226 & (3.2) & 226 & (3.2) & 226 & (3.4) \\
\hline${ }^{a} \mathrm{SO}_{2}$ (kTon) & 1,412 & 1,483 & $(5.0)$ & 1,487 & $(5.3)$ & 1,484 & $(5.1)$ & 1,472 & $(4.3)$ & 1,467 & (3.9) & 1,460 & (3.4) \\
\hline Avg wholsle price (\$/kWh) & 4.83 & 4.87 & $(0.9)$ & 4.88 & $(1.0)$ & 4.91 & $(1.6)$ & 4.92 & $(1.9)$ & 4.94 & $(2.2)$ & 4.98 & (3.1) \\
\hline Marg PHEV cost ( $\$ / k W h)$ & 0 & 4.26 & & 4.32 & & 4.73 & & 5.01 & & 5.22 & & 5.69 & \\
\hline \multicolumn{14}{|l|}{2030} \\
\hline Generation (TWh) & 365 & 378 & $(3.7)$ & 378 & $(3.7)$ & 378 & $(3.7)$ & 378 & $(3.7)$ & 378 & $(3.7)$ & 378 & (3.6) \\
\hline Unserved energy (TWh) & 0.0 & 0.0 & & 0.0 & & 0.0 & & 0.0 & & 0.0 & & 0.4 & \\
\hline Energy in (Quads) & 3.63 & 3.76 & $(3.4)$ & 3.76 & $(3.5)$ & 3.77 & $(3.7)$ & 3.77 & $(3.7)$ & 3.77 & $(3.8)$ & 3.78 & $(4.0)$ \\
\hline $\mathrm{CO}_{2}$ (MTon) & 241 & 252 & $(4.4)$ & 251 & $(4.3)$ & 251 & $(4.2)$ & 251 & $(4.2)$ & 251 & $(4.2)$ & 251 & $(4.1)$ \\
\hline${ }^{a} \mathrm{NO}_{\mathrm{x}}$ (kTon) & 214 & 225 & $(4.9)$ & 226 & $(5.3)$ & 228 & $(6.4)$ & 229 & $(6.7)$ & 229 & $(7.0)$ & 229 & $(7.0)$ \\
\hline${ }^{a} \mathrm{SO}_{2}$ (kTon) & 1,550 & 1,675 & $(8.1)$ & 1,668 & $(7.7)$ & 1,643 & $(6.0)$ & 1,644 & $(6.1)$ & 1,631 & $(5.3)$ & 1,608 & (3.8) \\
\hline Avg wholsle price (\$/kWh) & 4.80 & 4.89 & $(1.9)$ & 4.92 & $(2.4)$ & 5.05 & $(5.2)$ & 5.07 & $(5.7)$ & 5.19 & $(8.1)$ & 6.69 & $(39.4)$ \\
\hline Marg. PHEV cost ( $\$ / k W h)$ & 0 & 4.33 & & 4.46 & & 5.17 & & 5.20 & & 5.60 & & 10.84 & \\
\hline
\end{tabular}

${ }^{a} \mathrm{NO}_{\mathrm{x}}$ and $\mathrm{SO}_{2}$ emissions will be offset by reductions due to regulated caps.

The comparison between the fuel use, emissions, and cost for PHEVs in the region using gasoline versus electricity for the 20 miles per day is shown in Table 22. Note that because of the high amount of coal used for the PHEV generation in MAIN (Figure 20), $\mathrm{CO}_{2}$ emissions are higher with PHEVs than with efficient HEVs. $\mathrm{NO}_{\mathrm{X}}$ and $\mathrm{SO}_{2}$ emissions are higher as well, but these will be offset by reductions elsewhere in the electric system because of the legal caps on total emissions. Costs are much lower with the PHEVs, less than a third of the gasoline cost. Even if customer prices are triple from what is shown in Table 21 the customer would save money, and so likely would save money charging even at peak times. 
Table 22. Comparison of fuels, emissions, and costs for PHEVs using 2-kW recharging versus gasoline-fueled HEVs in MAIN, 2020 and 2030

\begin{tabular}{|c|c|c|c|c|c|c|}
\hline & \multicolumn{3}{|c|}{2020} & \multicolumn{3}{|c|}{2030} \\
\hline & \multirow[t]{2}{*}{$\begin{array}{c}\text { Gasoline- } \\
\text { fueled HEVs }\end{array}$} & \multicolumn{2}{|c|}{$\begin{array}{l}\text { PHEVs charged } \\
\text { from grid }\end{array}$} & \multirow[t]{2}{*}{$\begin{array}{c}\text { Gasoline- } \\
\text { fueled HEVs }\end{array}$} & \multicolumn{2}{|c|}{$\begin{array}{l}\text { PHEVs charged } \\
\text { from grid }\end{array}$} \\
\hline & & 2 kW night & $2 \mathrm{~kW}$ evening & & $2 \mathrm{~kW}$ night & $2 \mathrm{~kW}$ evening \\
\hline Vehicles (million) & 1.84 & & & 4.73 & & \\
\hline \multicolumn{7}{|l|}{ Fuel } \\
\hline - Oil (million barrel) & 8.0 & 0.0 & 0.0 & 20.6 & 0.0 & 0.1 \\
\hline - Coal (million ton) & & 2.09 & 1.50 & & 3.31 & 2.15 \\
\hline - Nat Gas (billion cuft) & & 10 & 27 & & 57 & 91 \\
\hline $\mathrm{CO} 2$ (million ton) & 3.3 & 5.1 & 4.8 & 8.4 & 10.4 & 10.0 \\
\hline${ }^{a} \mathrm{NO}_{\mathrm{x}}$ (thousand ton) & 0.7 & 5.6 & 7.1 & 1.9 & 11.3 & 14.9 \\
\hline${ }^{a} \mathrm{SO}_{2}$ (thousand ton) & 0 & 75 & 55 & & 119 & 82 \\
\hline${ }^{b}$ Cost (\$million) & 1,007 & 229 & 276 & 2,591 & 608 & 763 \\
\hline
\end{tabular}

${ }^{a} \mathrm{NO}_{x}$ and $\mathrm{SO}_{2}$ emissions will be offset by reductions due to regulated caps.

${ }^{b}$ This comparison does not include the added vehicle cost for PHEV batteries or recharging capability, nor the full retail price of electricity.

\subsection{Mid-Continent Area Power Pool (MAPP)}

Whether the electricity sector is able to satisfy the demand generated by the PHEVs in every moment of time depends on when hybrid owners plug in their vehicles for recharging. Night recharging of PHEVs shifts load curves to the valley and does not impose constraints on the system in this region (Table 23). Night recharging can affect peak loads in 2030 only if $6 \mathrm{~kW}$ charging is dominant. MAPP summer generating capacity $(42.6 \mathrm{GW})$ becomes insufficient to satisfy the demand that rises to over $44 \mathrm{GW}$ with $6 \mathrm{~kW}$ evening charging.

Table 23. Capacity and peak demand in each season under each charging scenario for 2020 and 2030 in MAPP (GW)

\begin{tabular}{|c|c|c|c|c|c|c|c|c|}
\hline & Capacity & $\begin{array}{c}\text { No } \\
\text { charging }\end{array}$ & $\begin{array}{c}1.4 \mathrm{~kW} \\
\text { night }\end{array}$ & $\begin{array}{l}2 \mathrm{~kW} \\
\text { night }\end{array}$ & $\begin{array}{l}6 \mathrm{~kW} \\
\text { night }\end{array}$ & $\begin{array}{c}1.4 \mathrm{~kW} \\
\text { evening }\end{array}$ & $\begin{array}{c}2 \mathrm{~kW} \\
\text { evening }\end{array}$ & $\begin{array}{c}6 \mathrm{~kW} \\
\text { evening }\end{array}$ \\
\hline \multicolumn{9}{|l|}{2020} \\
\hline Summer & 39.7 & 34.4 & 34.4 & 34.4 & 34.4 & 35.2 & 35.6 & 37.0 \\
\hline Winter & 40.9 & 29.2 & 29.2 & 29.2 & 29.2 & 30.2 & 30.6 & 32.0 \\
\hline Off-peak & 40.9 & 28.5 & 28.5 & 28.5 & 28.5 & 29.5 & 29.9 & 30.7 \\
\hline \multicolumn{9}{|l|}{2030} \\
\hline Summer & 42.6 & 37.3 & 37.3 & 37.3 & 38.6 & 39.5 & 40.6 & 44.1 \\
\hline Winter & 43.8 & 31.6 & 31.6 & 31.6 & 33.0 & 34.1 & 35.2 & 38.7 \\
\hline Off-peak & 43.8 & 30.9 & 30.9 & 30.9 & 31.5 & 33.4 & 34.5 & 37.3 \\
\hline
\end{tabular}

MAPP electricity generation is mainly based on coal with nuclear, hydro, gas, and renewable being the minor contributors (Figure 22 and Figure 23). Which plants are expected to satisfy the increased demand due to PHEVs depends on the recharging scenario chosen by the hybrids' owners. In case of night recharging, coal and gas plants will have to operate more. As charging power level increases, the share of coal decreases while gas use increases. With evening recharging, predominantly gas generators will satisfy the increased demand. A small amount of 
oil-fired generation will come on line during the highest demand times. A small amount of unserved energy has to be satisfied by import or additional capacity that is not currently planned.

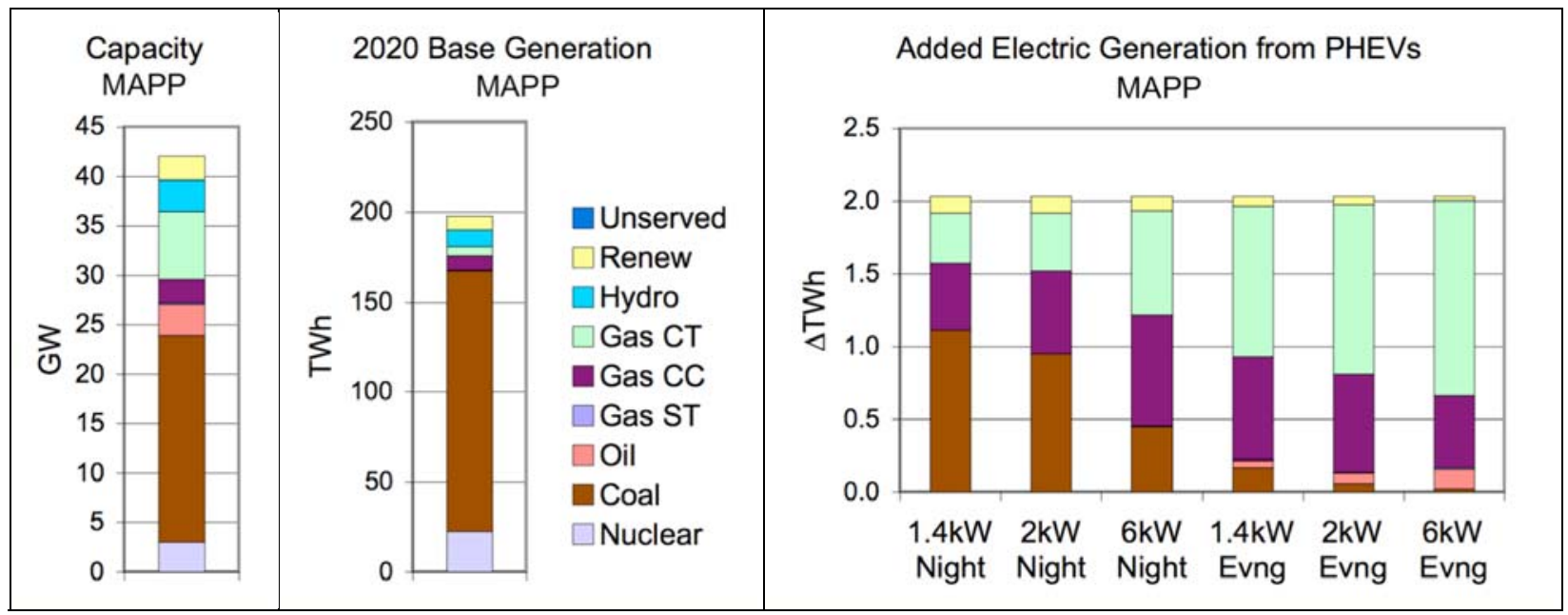

Figure 22. Projected 2020 generating capacity (left), base generation (center), and new generation dispatched to meet demand for each PHEV recharging scenario (right) for MAPP.
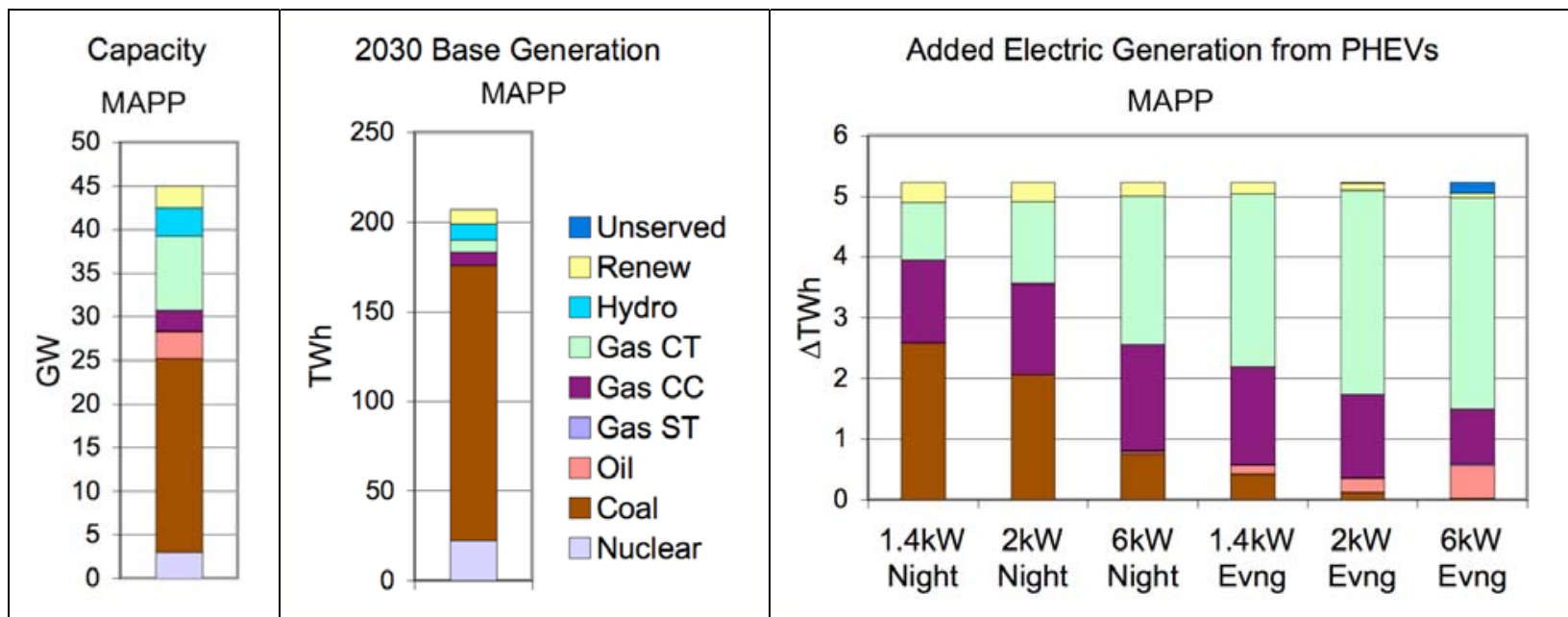

Figure 23. Projected 2030 generating capacity (left), base generation (center), and new generation dispatched to meet demand for each PHEV recharging scenario (right) for MAPP.

PHEVs slightly increase electricity generation, emission levels, and prices in this region (Table 24). Electricity generation increases by approximately $1 \%$ in 2020 and $2.5 \%$ in 2030 . On average, night recharging causes greater percentage changes in emissions levels (or rather, purchases of emission credits). $\mathrm{CO}_{2}, \mathrm{NO}_{\mathrm{X}}$ and $\mathrm{SO}_{2}$ are expected to increase by less than the amount of electricity increase. With emissions rates declining with increased evening charging, it appears that evening charging is puts less stress on the environment than the night plug in scenarios. Electricity prices are predicted to increase by $32 \%$ at most, which is less than in many other regions. 
Table 24. Generation, primary energy in, emissions, electricity prices, and PHEV charging costs in 2020 and 2030 for MAPP. Numbers in parentheses are percent change from no charging ("None").

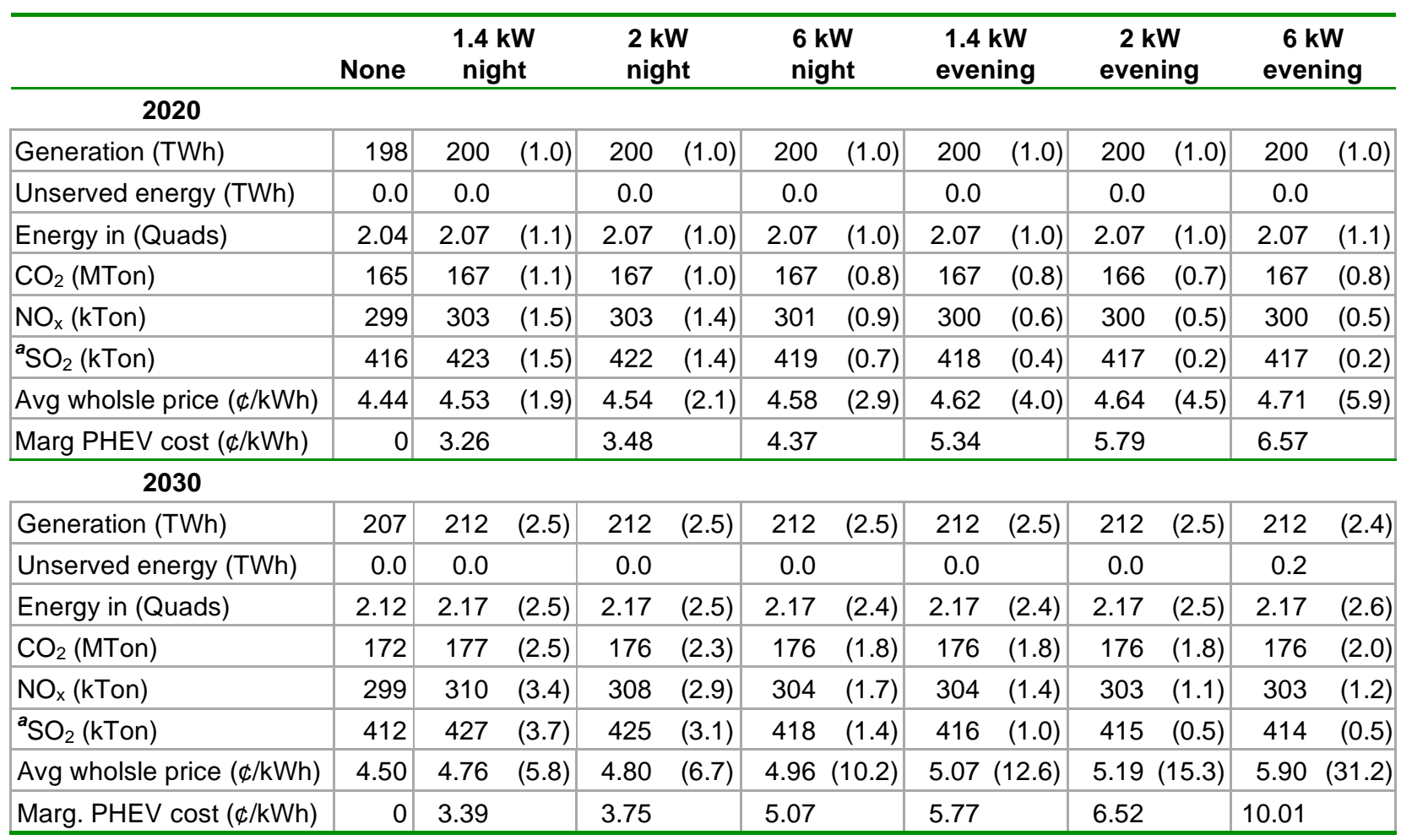

${ }^{a} \mathrm{SO}_{2}$ emissions will be offset by reductions due to regulated caps.

The comparison between the fuel use, emissions, and costs for PHEVs in the region using gasoline versus electricity for the 20 miles per day is shown in Table 25 . Note that because of the high amount of coal use for the PHEV generation in MAPP in the night scenarios and combustion turbine use in the evening scenarios (Figure 22), $\mathrm{CO}_{2}$ emissions are higher with PHEVs than with efficient HEVs. $\mathrm{NO}_{\mathrm{X}}$ and $\mathrm{SO}_{2}$ emissions are higher as well, but the $\mathrm{SO}_{2}$ will be offset by reductions elsewhere in the electric system because of the legal caps on total emissions. Costs are much lower with the PHEVs, less than a third of the gasoline cost. Even if customer prices are triple from what is shown in Table 24 the customer would save money, and so likely would save money charging even at peak times.

Table 25. Comparison of fuels, emissions, and costs for PHEVs using 2-kW recharging versus gasoline-fueled HEVs in MAPP, 2020 and 2030

\begin{tabular}{|c|c|c|c|c|c|c|}
\hline & \multicolumn{3}{|c|}{2020} & \multicolumn{3}{|c|}{2030} \\
\hline & \multirow[t]{2}{*}{$\begin{array}{c}\text { Gasoline- } \\
\text { fueled HEVs }\end{array}$} & \multicolumn{2}{|c|}{$\begin{array}{l}\text { PHEVs charged } \\
\text { from grid }\end{array}$} & \multirow[t]{2}{*}{$\begin{array}{c}\text { Gasoline- } \\
\text { fueled HEVs }\end{array}$} & \multicolumn{2}{|c|}{$\begin{array}{l}\text { PHEVs charged } \\
\text { from grid }\end{array}$} \\
\hline & & 2 kW night & $2 \mathrm{~kW}$ evening & & $2 \mathrm{~kW}$ night & $2 \mathrm{~kW}$ evening \\
\hline Vehicles (million) & 0.71 & & & 1.81 & & \\
\hline \multicolumn{7}{|l|}{ Fuel } \\
\hline - Oil (million barrel) & 3.1 & 0.0 & 0.2 & 7.9 & 0.0 & 0.6 \\
\hline - Coal (million ton) & & 0.56 & 0.04 & & 1.22 & 0.08 \\
\hline - Nat Gas (billion cuft) & & 8 & 18 & & 22 & 45 \\
\hline CO2 (million ton) & 1.2 & 1.7 & 1.2 & 3.2 & 3.9 & 3.1 \\
\hline
\end{tabular}




\begin{tabular}{|c|c|c|c|c|c|c|}
\hline & \multicolumn{3}{|c|}{2020} & \multicolumn{3}{|c|}{2030} \\
\hline & \multirow[t]{2}{*}{$\begin{array}{c}\text { Gasoline- } \\
\text { fueled HEVs }\end{array}$} & \multicolumn{2}{|c|}{$\begin{array}{l}\text { PHEVs charged } \\
\text { from grid }\end{array}$} & \multirow[t]{2}{*}{$\begin{array}{c}\text { Gasoline- } \\
\text { fueled HEVs }\end{array}$} & \multicolumn{2}{|c|}{$\begin{array}{l}\text { PHEVs charged } \\
\text { from grid }\end{array}$} \\
\hline & & 2 kW night & $2 \mathrm{~kW}$ evening & & 2 kW night & $2 \mathrm{~kW}$ evening \\
\hline $\mathrm{NO}_{\mathrm{x}}$ (thousand ton) & 0.3 & 4.2 & 1.5 & 0.7 & 8.8 & 3.2 \\
\hline${ }^{a} \mathrm{SO}_{2}$ (thousand ton) & 0 & 6 & 1 & & 13 & 2 \\
\hline${ }^{b}$ Cost (\$million) & 386 & 71 & 118 & 994 & 196 & 341 \\
\hline
\end{tabular}

${ }^{a} \mathrm{SO}_{2}$ emissions will be offset by reductions due to regulated caps.

${ }^{b}$ This comparison does not include the added vehicle cost for PHEV batteries or recharging capability, nor the full retail price of electricity.

\subsection{Northeast Power Coordinating Council - New York (NPCC - NY)}

In 2020, the night recharging patterns do not significantly change the peaks, and even the evening charging scenarios do not approach the local generation capacity (Table 26). Even in the 2030 scenarios, summer peaks remain below the region's capacity of $46.7 \mathrm{GW}$.

Table 26. Capacity and peak demand in each season under each charging scenario for 2020 and 2030 in NPCC-NY (GW)

\begin{tabular}{cccccc|ccc}
\hline & Capacity & $\begin{array}{c}\text { No } \\
\text { charging }\end{array}$ & $\begin{array}{c}\mathbf{1 . 4} \mathbf{~ k W} \\
\text { night }\end{array}$ & $\begin{array}{c}\mathbf{2} \mathbf{k W} \\
\text { night }\end{array}$ & $\begin{array}{c}\mathbf{6} \mathbf{~ k W} \\
\text { night }\end{array}$ & $\begin{array}{c}\mathbf{1 . 4} \mathbf{~ k W} \\
\text { evening }\end{array}$ & $\begin{array}{c}\mathbf{2} \mathbf{k W} \\
\text { evening }\end{array}$ & $\begin{array}{c}\mathbf{6} \mathbf{k W} \\
\text { evening }\end{array}$ \\
\hline $\begin{array}{c}\mathbf{2 0 2 0} \\
\text { Summer }\end{array}$ & 41.5 & 34.2 & 34.2 & 34.2 & 34.2 & 34.4 & 34.7 & 36.5 \\
Winter & 43.4 & 26.6 & 26.6 & 26.6 & 26.6 & 27.9 & 28.5 & 30.3 \\
Off-peak & 43.4 & 24.8 & 24.8 & 24.8 & 24.8 & 26.1 & 26.7 & 28.5 \\
\hline $\mathbf{2 0 3 0}$ & & & & & & & & \\
Summer & 46.7 & 36.1 & 36.1 & 36.1 & 37.4 & 37.8 & 39.3 & 44.0 \\
Winter & 46.5 & 28.0 & 28.0 & 28.0 & 31.1 & 31.4 & 32.8 & 37.5 \\
Off-peak & 46.5 & 26.2 & 26.2 & 26.2 & 29.6 & 29.5 & 31.0 & 35.7 \\
\hline
\end{tabular}

The generation mix of the NPCC - NY area is highly diversified and includes coal, oil, gas, nuclear power, hydro, and renewable sources (Figure 24). In spite of this, the 2020 incremental generation comes predominantly from oil-fired capacity. These plants, although providing less than $7 \%$ of the total generation, are at the point in the loading order where they are called upon frequently. The large amount of hydro generation partially accounts for this, in that hydro production is used preferentially to reduce the operations of peaking units. As PHEVs increase demand, the hydro generation reacts by shifting its production, letting more of the less expensive peaking generation be dispatched.

The 2030 added generation is predominantly gas, and to a much lesser extent coal and oil are expected to satisfy incremental demand caused by the PHEVs (Figure 25). Under the evening recharging scenario the oil share increases as analyzed battery power level goes up. Introduction of PHEVs will not make renewable energy generators produce more. The $6 \mathrm{~kW}$ charging in the evening creates excessive demand, which cannot be satisfied by the plants in place and by those planned now. 


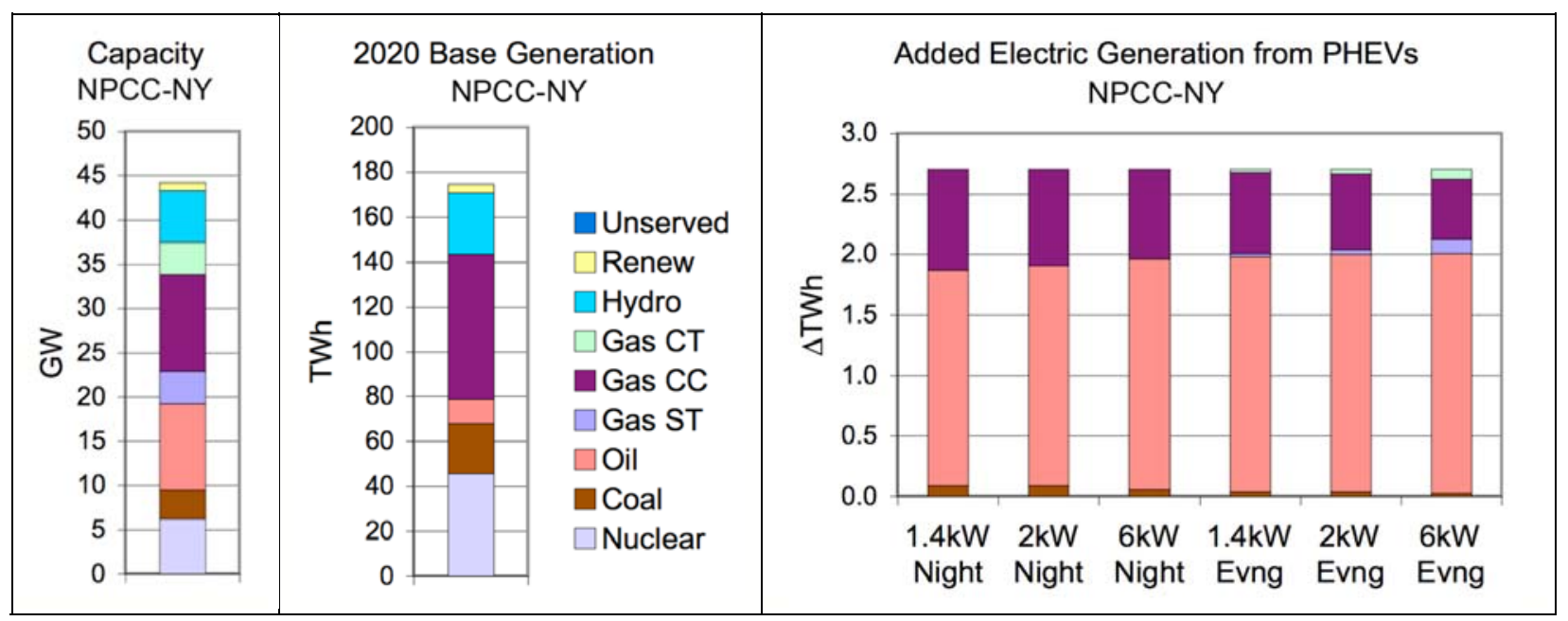

Figure 24. Projected 2020 generating capacity (left), base generation (center), and new generation dispatched to meet demand for each PHEV recharging scenario (right) for NPCC-NY.

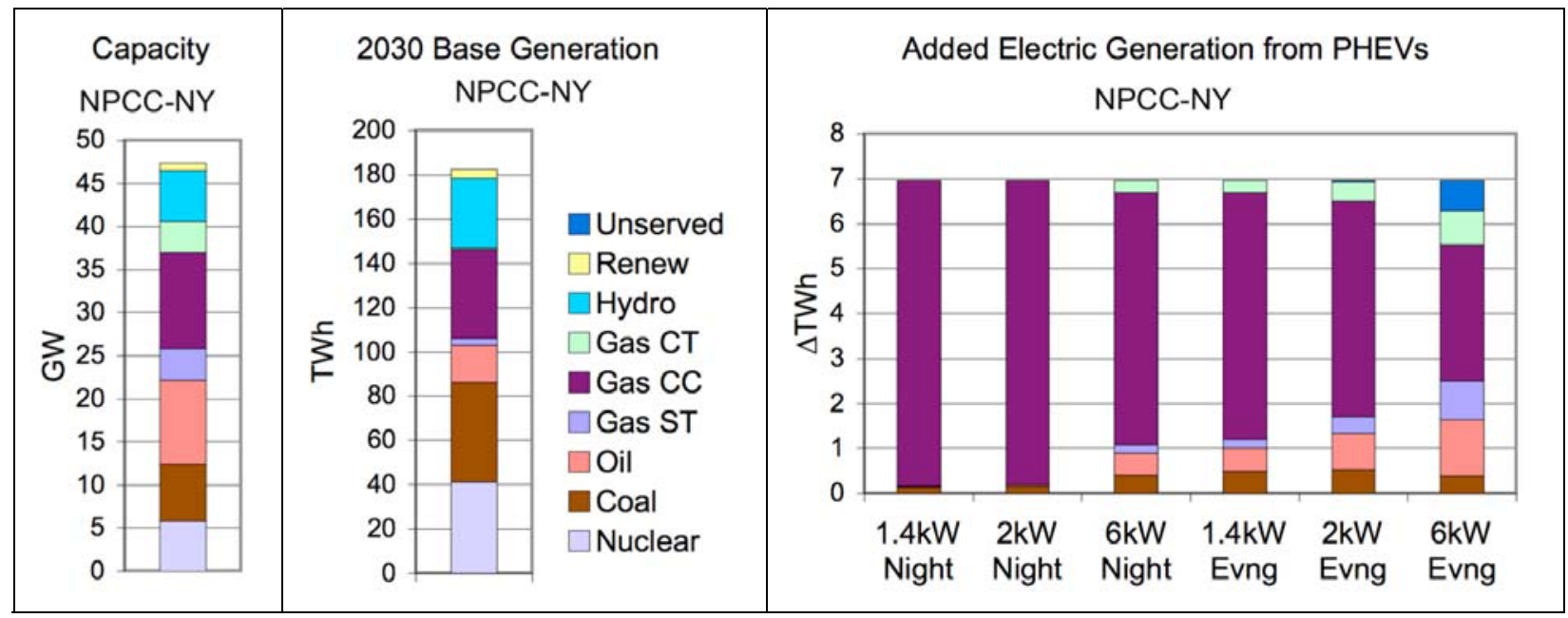

Figure 25. Projected 2030 generating capacity (left), base generation (center), and new generation dispatched to meet demand for each PHEV recharging scenario (right) for NPCC-NY.

With respect to changes in supply, prices, and emissions, NPCC $-\mathrm{NY}$ is similar to most other regions in some respects and different in others. The generation increase is comparable to that of the other regions, $1.5 \%$ in 2020 and $3.8 \%$ in 2030 (Table 27). Emissions and price changes in 2020 are relatively flat across the spectrum of scenarios as a consequence of hydro power flattening the load shape so that production is similar in all cases.

By 2030 the generation mix changes, with consequent impacts on the emissions and costs. In the night charging scenarios, gas-fired combined cycle plants provide most of the marginal production, but the evening scenarios include a mix of coal and oil- and gas-fired turbines. This raises the emissions in the evening scenarios so that night charging is less polluting in this region. While there is excess capacity in the region, capacity factors for hydro and other generation technologies is such that there is a small amount of unserved energy. 
Table 27. Generation, primary energy in, emissions, electricity prices, and PHEV charging costs in 2020 and 2030 for NPCC-NY. Numbers in parentheses are percent change from no charging ("None").

\begin{tabular}{|c|c|c|c|c|c|c|c|c|c|c|c|c|c|}
\hline & None & \multicolumn{2}{|c|}{$\begin{array}{c}1.4 \mathrm{~kW} \\
\text { night }\end{array}$} & \multicolumn{2}{|c|}{$\begin{array}{l}2 \mathrm{~kW} \\
\text { night }\end{array}$} & \multicolumn{2}{|c|}{$\begin{array}{l}6 \mathrm{~kW} \\
\text { night }\end{array}$} & \multicolumn{2}{|c|}{$\begin{array}{c}1.4 \mathrm{~kW} \\
\text { evening }\end{array}$} & \multicolumn{2}{|c|}{$\begin{array}{c}2 \mathrm{~kW} \\
\text { evening }\end{array}$} & \multicolumn{2}{|c|}{$\begin{array}{c}6 \mathrm{~kW} \\
\text { evening }\end{array}$} \\
\hline \multicolumn{14}{|l|}{2020} \\
\hline Generation (TWh) & 175 & 178 & $(1.5)$ & 178 & (1.5) & 178 & (1.5) & 178 & (1.5) & 178 & (1.5) & 178 & (1.5) \\
\hline Unserved energy ( $\mathrm{T}$ & 0.0 & 0.0 & & 0.0 & & 0.0 & & 0.0 & & 0.0 & & 0.0 & \\
\hline Energy in (Quads) & 1.61 & 1.64 & (1.6) & 1.64 & (1.6) & 1.64 & (1.7) & 1.64 & (1.7) & 1.64 & $(1.7)$ & 1.64 & (1.7) \\
\hline $\mathrm{CO}_{2}$ (MTon) & 62 & 64 & (3.4) & 64 & (3.5) & 64 & (3.5) & 64 & (3.5) & 64 & (3.6) & 64 & (3.6) \\
\hline${ }^{a} \mathrm{NO}_{\mathrm{x}}$ (kTon) & 53 & 56 & (4.7) & 56 & (4.6) & 56 & (4.4) & 55 & (4.1) & 55 & $(4.0)$ & 55 & (4.0) \\
\hline${ }^{a} \mathrm{SO}_{2}$ (kTon) & 245 & 251 & (2.4) & 251 & (2.5) & 251 & (2.5) & 251 & (2.6) & 252 & (2.6) & 251 & $(2.6)$ \\
\hline Avg wholsle pr & 4.69 & 4.73 & $(0.9)$ & 4.74 & $(1.0)$ & 4.73 & $(0.8)$ & 4.75 & (1.4) & 4.75 & (1.3) & 4.76 & $(1.5)$ \\
\hline Marg PHEV cost & 0 & 5.49 & & 5.57 & & 4.90 & & 5.80 & & 6.02 & & 5.86 & \\
\hline \multicolumn{14}{|l|}{2030} \\
\hline Generation (TWh) & 183 & 190 & (3.8) & 190 & (3.8) & 190 & $(3.8)$ & 190 & (3.8) & 190 & (3.8) & 189 & (3.4) \\
\hline Unserved energy ( $\mathrm{T}$ & 0 & 0.0 & & 0.0 & & 0.0 & & 0.0 & & 0.0 & & 0.7 & \\
\hline Energy in (Quads) & 1.74 & 1.79 & (3.0) & 1.79 & (3.0) & 1.79 & (3.3) & 1.79 & (3.3) & 1.80 & (3.5) & 1.80 & (3.6) \\
\hline $\mathrm{CO}_{2}$ (MTon) & 80 & 83 & (3.9) & 83 & (3.9) & 84 & (4.6) & 84 & (4.7) & 84 & $(5.1)$ & 84 & $(5.4)$ \\
\hline${ }^{a} \mathrm{NO}_{x}$ (kTon) & 59 & 59 & (1.4) & 60 & (1.7) & 61 & (4.7) & 62 & (5.4) & 62 & (6.7) & 63 & (7.9) \\
\hline${ }^{a} \mathrm{SO}_{2}$ (kTon) & 230 & 232 & (1.0) & 233 & (1.1) & 238 & (3.4) & 239 & (4.0) & 241 & $(4.7)$ & 239 & $(4.1)$ \\
\hline Avg wholsle price ( $(\mathrm{kWh})$ & 4.37 & 4.39 & $(0.5)$ & 4.40 & $(0.6)$ & 4.57 & $(4.5)$ & 4.61 & $(5.4)$ & 4.91 & $(12.2)$ & 9.33 & (113) \\
\hline Marg. PHEV cost (\$/kWh) & 0 & 4.54 & & 4.60 & & 5.06 & & 5.17 & & 5.83 & & 32.95 & \\
\hline
\end{tabular}

${ }^{a} \mathrm{NO}_{x}$ and $\mathrm{SO}_{2}$ emissions will be offset by reductions due to regulated caps.

The comparison between fuel use, emissions, and costs for the PHEV vehicles in the region using gasoline versus electricity for the 20 miles per day is shown in Table 28. Note that because of the high amount of oil use for generation for PHEVs in NPCC-NY in the 2020 scenarios (Figure 24), $\mathrm{CO}_{2}$ emissions are higher with PHEVs than with efficient HEVs. In the 2030 scenarios, though, the marginal technology is gas-fired combined cycle (Figure 25). $\mathrm{CO}_{2}$ emissions are lower for PHEVs than for the gas-fueled cars. $\mathrm{NO}_{\mathrm{X}}$ and $\mathrm{SO}_{2}$ emissions are higher as well, but these will be offset by reductions elsewhere in the electric system because of the legal caps on total emissions. In the 2030 night charging scenario, the $\mathrm{NO}_{\mathrm{X}}$ emissions are lower than for gas-fueled vehicles because of the clean combined cycle plants that are the marginal generators. Costs are much lower with the PHEVs, less than a third of the gasoline cost. Even if prices are triple from what is shown in Table 27 the customer would save money, and so likely would save money charging even at peak times. 
Table 28. Comparison of fuels, emissions, and costs for PHEVs using $2-\mathrm{kW}$ recharging versus gasoline-fueled HEVs in NPCC-NY, 2020 and 2030

\begin{tabular}{|c|c|c|c|c|c|c|}
\hline & \multicolumn{3}{|c|}{2020} & \multicolumn{3}{|c|}{2030} \\
\hline & \multirow[t]{2}{*}{$\begin{array}{c}\text { Gasoline- } \\
\text { fueled HEVs }\end{array}$} & \multicolumn{2}{|c|}{$\begin{array}{l}\text { PHEVs charged } \\
\text { from grid }\end{array}$} & \multirow[t]{2}{*}{$\begin{array}{c}\text { Gasoline- } \\
\text { fueled HEVs }\end{array}$} & \multicolumn{2}{|c|}{$\begin{array}{l}\text { PHEVs charged } \\
\text { from grid }\end{array}$} \\
\hline & & $2 \mathrm{~kW}$ night & $2 \mathrm{~kW}$ evening & & $2 \mathrm{~kW}$ night & $2 \mathrm{~kW}$ evening \\
\hline Vehicles (million) & 0.94 & & & 2.42 & & \\
\hline \multicolumn{7}{|l|}{ Fuel } \\
\hline - Oil (million barrel) & 4.1 & 3.7 & 4.0 & 10.5 & 0.1 & 1.7 \\
\hline - Coal (million ton) & & 0.06 & 0.02 & & 0.09 & 0.32 \\
\hline - Nat Gas (billion cuft) & & 6 & 6 & & 48 & 44 \\
\hline $\mathrm{CO} 2$ (million ton) & 1.7 & 2.2 & 2.2 & 4.3 & 3.1 & 4.1 \\
\hline${ }^{a} \mathrm{NO}_{\mathrm{x}}$ (thousand ton) & 0.4 & 2.5 & 2.1 & 1.0 & 1.0 & 3.9 \\
\hline${ }^{a} \mathrm{SO}_{2}$ (thousand ton) & 0 & 6 & 6 & & 3 & 11 \\
\hline${ }^{b}$ Cost (\$million) & 514 & 151 & 163 & 1,324 & 321 & 406 \\
\hline
\end{tabular}

${ }^{a} \mathrm{NO}_{x}$ and $\mathrm{SO}_{2}$ emissions will be offset by reductions due to regulated caps.

${ }^{b}$ This comparison does not include the added vehicle cost for PHEV batteries or recharging capability, nor the full retail price of electricity.

\subsection{Northeast Power Coordinating Council - New England (NPCC -NE)}

Table 29 shows the available capacity and peak demand in each season for each of the scenarios studied. For night charging the model results suggest that there should be sufficient capacity available to satisfy additional demand. Peak demands do not rise except in the winter and offpeak seasons with $6 \mathrm{~kW}$ charging. The evening scenarios have a large impact, most notably an increasing impact in the winter and off-peak seasons. Summer peaks do not rise as much, but the summer peak in 2030 does exceed capacity in the case of the $6 \mathrm{~kW}$ evening charging, causing a small amount of unserved energy.

Table 29. Capacity and peak demand in each season under each charging scenario for 2020 and 2030 in NPCC-NE (GW)

\begin{tabular}{|c|c|c|c|c|c|c|c|c|}
\hline & Capacity & $\begin{array}{c}\text { No } \\
\text { charging }\end{array}$ & $\begin{array}{c}1.4 \mathrm{~kW} \\
\text { night }\end{array}$ & $\begin{array}{l}2 \mathrm{~kW} \\
\text { night }\end{array}$ & $\begin{array}{l}6 \mathrm{~kW} \\
\text { night }\end{array}$ & $\begin{array}{c}1.4 \mathrm{~kW} \\
\text { evening }\end{array}$ & $\begin{array}{c}2 \mathrm{~kW} \\
\text { evening }\end{array}$ & $\begin{array}{c}6 \mathrm{~kW} \\
\text { evening }\end{array}$ \\
\hline \multicolumn{9}{|l|}{2020} \\
\hline Summer & 35.2 & 31.9 & 31.9 & 31.9 & 31.9 & 31.9 & 31.9 & 33.5 \\
\hline Winter & 37.4 & 26.3 & 26.3 & 26.3 & 26.3 & 27.7 & 28.4 & 30.4 \\
\hline Off-peak & 37.4 & 24.0 & 24.0 & 24.0 & 24.0 & 25.4 & 26.0 & 28.0 \\
\hline \multicolumn{9}{|l|}{2030} \\
\hline Summer & 39.9 & 34.0 & 34.0 & 34.0 & 34.0 & 34.7 & 36.3 & 41.4 \\
\hline Winter & 42.1 & 27.8 & 27.8 & 27.8 & 30.6 & 31.5 & 33.1 & 38.3 \\
\hline Off-peak & 42.1 & 25.4 & 25.4 & 25.4 & 28.2 & 29.1 & 30.7 & 35.9 \\
\hline
\end{tabular}

New England region's main source of electric power is gas, followed by nuclear. Although there is significant oil capacity in the region, it is little used. Coal, hydro, and renewable technologies are also available but provide smaller amounts (Figure 26 and Figure 27). Oil generation plays an increasing role on the margin with the addition of PHEV loads, even though it only provides a small fraction of the total electricity for the region. Renewable plants also contribute to generation for the PHEVs, mainly biomass plants burning wood. The night charging demand is 
largely met by combined cycle generation, but this declines as generation is needed more during peak times.

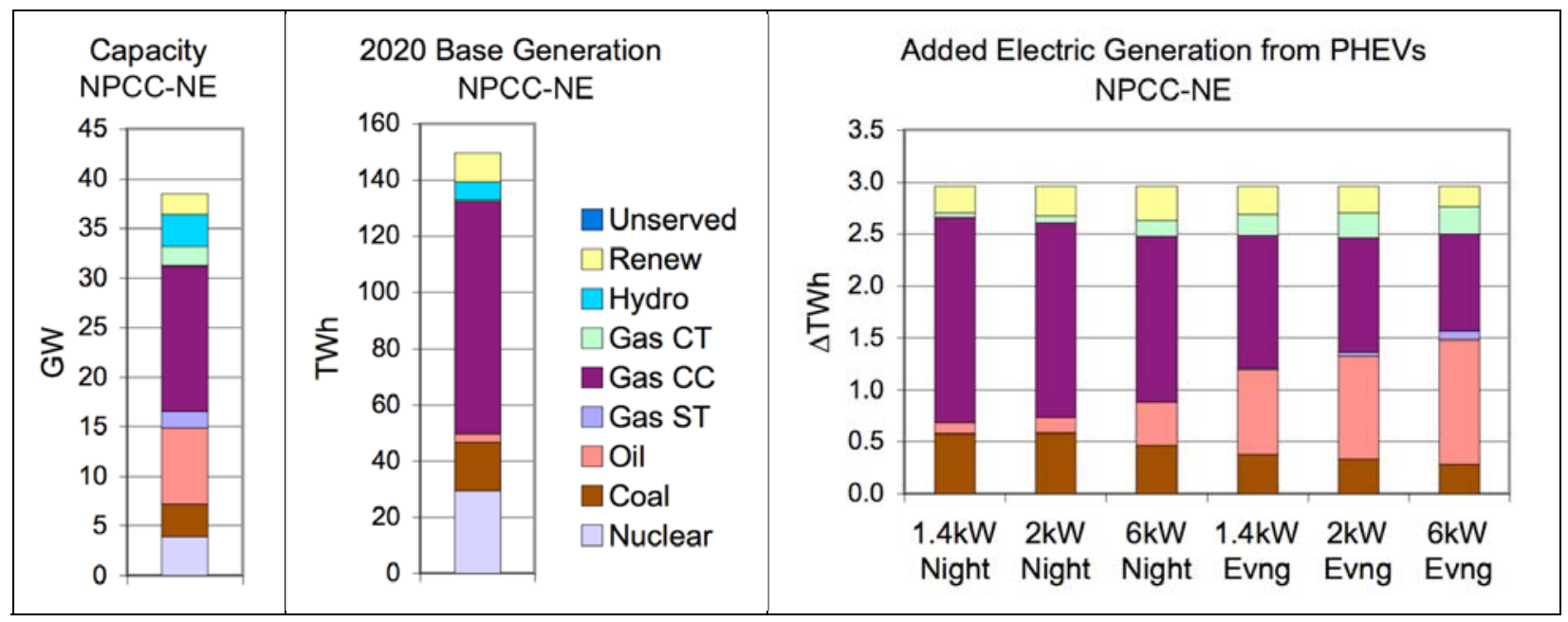

Figure 26. Projected 2020 generating capacity (left), base generation (center), and new generation dispatched to meet demand for each PHEV recharging scenario (right) for NPCC-NE.

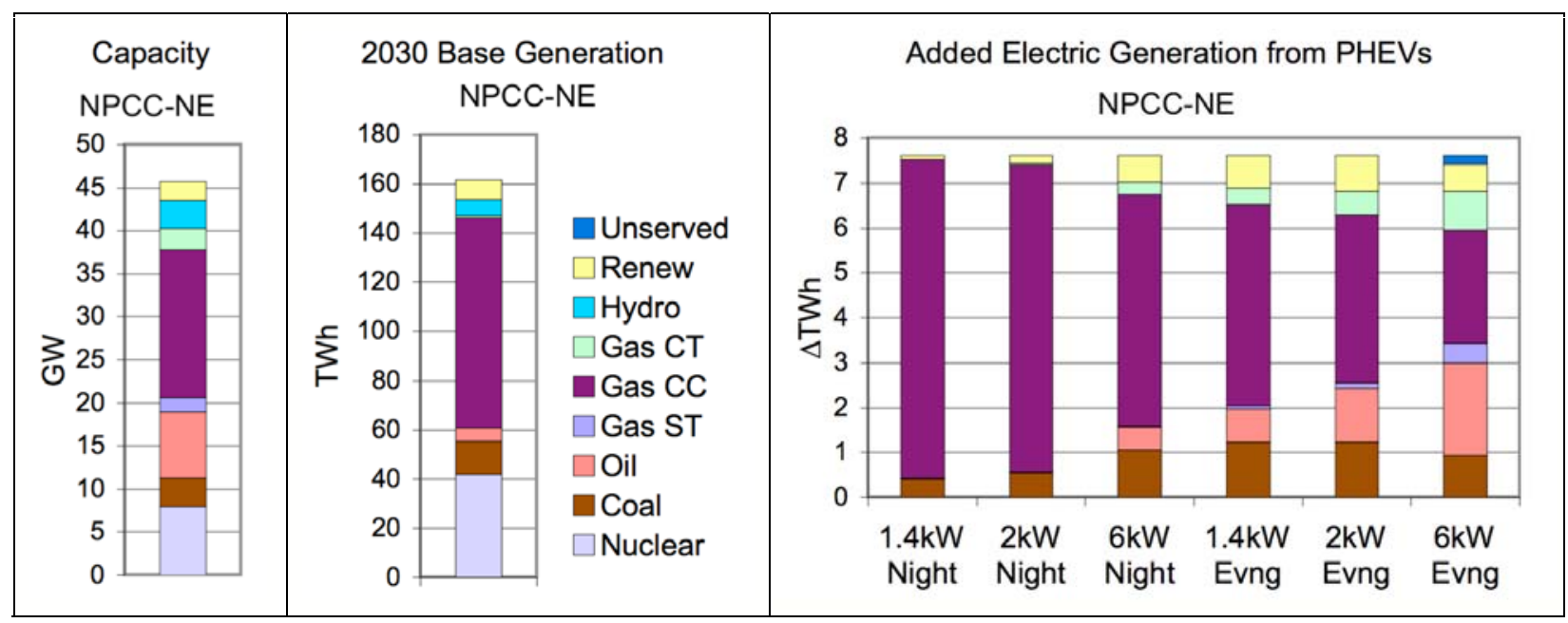

Figure 27. Projected 2030 generating capacity (left), base generation (center), and new generation dispatched to meet demand for each PHEV recharging scenario (right) for NPCC-NE.

In this region the introduction of PHEVs drives generation up by $2 \%$ in 2020 and $4.7 \%$ by 2030 . Because of the change from clean combined cycle to dirtier oil, gas turbine, and coal production, emissions increase with more evening generation. $\mathrm{CO}_{2}, \mathrm{NO}_{\mathrm{X}}$ and $\mathrm{SO}_{2}$ emissions may increase by as much as $26 \%$. The price is less sensitive at lower power levels and more sensitive for $6 \mathrm{~kW}$ evening charging. However, the largest predicted increase is only $42 \%$ higher than the base predicted price. Of course, $\mathrm{NO}_{\mathrm{X}}$ and $\mathrm{SO}_{2}$ emissions are capped so net new emissions will be zero. 
Table 30. Generation, primary energy in, emissions, electricity prices, and PHEV charging costs in 2020 and 2030 for NPCC-NE. Numbers in parentheses are percent change from no charging ("None").

\begin{tabular}{|c|c|c|c|c|c|c|c|c|c|c|c|c|c|}
\hline & None & \multicolumn{2}{|c|}{$\begin{array}{c}1.4 \mathrm{~kW} \\
\text { night }\end{array}$} & \multicolumn{2}{|c|}{$\begin{array}{l}2 \mathrm{~kW} \\
\text { night }\end{array}$} & \multicolumn{2}{|c|}{$\begin{array}{l}6 \mathrm{~kW} \\
\text { night }\end{array}$} & \multicolumn{2}{|c|}{$\begin{array}{c}1.4 \mathrm{~kW} \\
\text { evening }\end{array}$} & \multicolumn{2}{|c|}{$\begin{array}{c}2 \mathrm{~kW} \\
\text { evening }\end{array}$} & \multicolumn{2}{|c|}{$\begin{array}{c}6 \mathrm{~kW} \\
\text { evening }\end{array}$} \\
\hline \multicolumn{14}{|l|}{2020} \\
\hline Generation (TWh) & 149 & 152 & (2.0) & 152 & (2.0) & 152 & (2.0) & 152 & (2.0) & 152 & (2.0) & 152 & (2.0) \\
\hline Unserved energy ( $\mathrm{T}$ & 0.0 & 0.0 & & 0.0 & & 0.0 & & 0.0 & & 0.0 & & 0.0 & \\
\hline Energy in (Quads) & 1.30 & 1.32 & (2.0) & 1.32 & $(2.1)$ & 1.32 & (2.2) & 1.33 & (2.3) & 1.33 & (2.4) & 1.33 & (2.4) \\
\hline $\mathrm{CO}_{2}$ (MTon) & 56 & 58 & (2.8) & 58 & (2.9) & 58 & (3.0) & 58 & (3.4) & 58 & (3.6) & 58 & (3.8) \\
\hline${ }^{a} \mathrm{NO}_{\mathrm{x}}$ (kTon) & 44 & 45 & (2.3) & 45 & (2.6) & 45 & (3.1) & 46 & (4.5) & 46 & (5.1) & 46 & (5.7) \\
\hline${ }^{a} \mathrm{SO}_{2}$ (kTon) & 130 & 138 & (6.0) & 138 & (6.5) & 139 & (6.9) & 140 & (8.0) & 141 & (8.5) & 142 & $(9.0)$ \\
\hline Avg wholsle pr & 5.28 & 5.34 & (1.1) & 5.35 & (1.4) & 5.36 & (1.6) & 5.38 & (1.9) & 5.39 & (2.1) & 5.42 & (2.6) \\
\hline IEV cost & 0 & 4.95 & & 5.19 & & 5.19 & & 5.54 & & 5.72 & & 6.16 & \\
\hline \multicolumn{14}{|l|}{2030} \\
\hline Generation (TV & 162 & 169 & $(4.7)$ & 169 & $(4.7)$ & 169 & $(4.7)$ & 169 & (4.7) & 169 & (4.7) & 169 & (4.6) \\
\hline Unserved e & 0.0 & 0.0 & & 0.0 & & 0.0 & & 0.0 & & 0.0 & & 0.2 & \\
\hline Energy in (Quads) & 1.39 & 1.44 & (4.2) & 1.45 & $(4.3)$ & 1.45 & $(5.0)$ & 1.46 & (5.2) & 1.46 & (5.5) & 1.47 & (5.7) \\
\hline $\mathrm{CO}_{2}$ (MTon) & 55 & 58 & (6.4) & 58 & (6.5) & 59 & (7.4) & 59 & (7.8) & 59 & (8.4) & 60 & $(9.4)$ \\
\hline${ }^{a} \mathrm{NO}_{\mathrm{x}}$ (kTon) & 39 & 41 & (3.7) & 41 & $(4.7)$ & & (8.8) & & $(10.1)$ & 44 & (12.1) & 45 & $(14.6)$ \\
\hline${ }^{\mathrm{a}} \mathrm{SO}_{2}$ (kTon) & 100 & 103 & (3.6) & 105 & $(5.3)$ & 116 & $(16.3)$ & 120 & (20.6) & 124 & (24.2) & 126 & $(26.4)$ \\
\hline Avg wholsle price ( $₫ / k W h)$ & 4.87 & 4.89 & $(0.4)$ & 4.92 & $(1.0)$ & 5.06 & (4.0) & 5.11 & (5.0) & 5.19 & (6.5) & 6.73 & $(38.3)$ \\
\hline Marg. PHEV cost ( $\$ / k W h)$ & 0 & 4.42 & & 4.55 & & 4.95 & & 5.09 & & 5.38 & & 10.19 & \\
\hline
\end{tabular}

${ }^{a} \mathrm{NO}_{x}$ and $\mathrm{SO}_{2}$ emissions will be offset by reductions due to regulated caps.

The comparison between fuel use, emissions, and cost for PHEV vehicles in the region using gasoline versus electricity for the 20 miles per day is shown in Table $31 . \mathrm{CO}_{2}$ emissions are lower for the PHEVs except for $2 \mathrm{~kW}$ night charging in 2020. The region has a large amount of renewable energy (with no net $\mathrm{CO}_{2}$ ) and efficient combined cycle generation to keep the emissions low (Figure 26). Evening charging at $2 \mathrm{~kW}$ in 2020, however, uses a large amount of oil generation. $\mathrm{NO}_{\mathrm{X}}$ and $\mathrm{SO}_{2}$ emissions are higher as well, but these will be offset by reductions elsewhere in the electric system because of the legal caps on total emissions. Costs are much lower with the PHEVs, less than a third of the gasoline cost. Even if customer prices are triple from what is shown in Table 30 the customer would save money, and so likely would save money charging even at peak times.

Table 31. Comparison of fuels, emissions, and costs for PHEVs using 2-kW recharging versus gasoline-fueled HEVs in NPCC-NE, 2020 and 2030

\begin{tabular}{|c|c|c|c|c|c|c|}
\hline & \multicolumn{3}{|c|}{2020} & \multicolumn{3}{|c|}{2030} \\
\hline & \multirow[t]{2}{*}{$\begin{array}{c}\text { Gasoline- } \\
\text { fueled HEVs }\end{array}$} & \multicolumn{2}{|c|}{$\begin{array}{l}\text { PHEVs charged } \\
\text { from grid }\end{array}$} & \multirow[t]{2}{*}{$\begin{array}{c}\text { Gasoline- } \\
\text { fueled HEVs }\end{array}$} & \multicolumn{2}{|c|}{$\begin{array}{l}\text { PHEVs charged } \\
\text { from grid }\end{array}$} \\
\hline & & 2 kW Night & $\begin{array}{c}2 \mathrm{~kW} \\
\text { Evening }\end{array}$ & & 2 kW Night & $\begin{array}{c}2 \mathrm{~kW} \\
\text { Evening }\end{array}$ \\
\hline Vehicles (million) & 1.03 & & & 2.64 & & \\
\hline \multicolumn{7}{|l|}{ Fuel } \\
\hline - Oil (million barrel) & 4.5 & 0.3 & 2.0 & 11.5 & 0.0 & 2.5 \\
\hline - Coal (million ton) & & 0.30 & 0.19 & & 0.28 & 0.65 \\
\hline
\end{tabular}




\begin{tabular}{|c|c|c|c|c|c|c|}
\hline & \multicolumn{3}{|c|}{2020} & \multicolumn{3}{|c|}{2030} \\
\hline & \multirow[t]{2}{*}{$\begin{array}{c}\text { Gasoline- } \\
\text { fueled HEVs }\end{array}$} & \multicolumn{2}{|c|}{$\begin{array}{l}\text { PHEVs charged } \\
\text { from grid }\end{array}$} & \multirow[t]{2}{*}{$\begin{array}{c}\text { Gasoline- } \\
\text { fueled HEVs }\end{array}$} & \multicolumn{2}{|c|}{$\begin{array}{l}\text { PHEVs charged } \\
\text { from grid }\end{array}$} \\
\hline & & 2 kW Night & $\begin{array}{c}2 \mathrm{~kW} \\
\text { Evening }\end{array}$ & & 2 kW Night & $\begin{array}{c}2 \mathrm{~kW} \\
\text { Evening }\end{array}$ \\
\hline - Nat Gas (billion cuft) & & 15 & 12 & & 49 & 35 \\
\hline $\mathrm{CO}_{2}$ (million ton) & 1.8 & 1.6 & 2.0 & 4.7 & 3.6 & 4.6 \\
\hline${ }^{a} \mathrm{NO}_{\mathrm{x}}$ (thousand ton) & 0.4 & 1.1 & 2.2 & 1.1 & 1.9 & 4.7 \\
\hline${ }^{a} \mathrm{SO}_{2}$ (thousand ton) & 0 & 8 & 11 & & 5 & 24 \\
\hline${ }^{b}$ Cost (\$million) & 562 & 154 & 169 & 1,447 & 346 & 410 \\
\hline
\end{tabular}

${ }^{a} \mathrm{NO}_{\mathrm{x}}$ and $\mathrm{SO}_{2}$ emissions will be offset by reductions due to regulated caps.

${ }^{b}$ This comparison does not include the added vehicle cost for PHEV batteries or recharging capability, nor the full retail price of electricity.

\subsection{Florida Reliability Coordinating Council (FRCC)}

In FRCC the $64.5 \mathrm{GW}$ summer capacity in 2020 just equals the peak demand in the $6 \mathrm{~kW}$ evening scenario (Table 32). The $79.3 \mathrm{GW}$ generating capacity of the FRCC region in 2030 is under the $84.4 \mathrm{GW}$ highest peak demand. If recharged during the nights, the PHEVs only shift load curves right to the valleys and do not affect peak values.

Table 32. Capacity and peak demand in each season under each charging scenario for 2020 and 2030 in FRCC (GW)

\begin{tabular}{cccccc|ccc}
\hline & Capacity & $\begin{array}{c}\text { No } \\
\text { charging }\end{array}$ & $\begin{array}{c}\mathbf{1 . 4} \mathbf{~ k W} \\
\text { night }\end{array}$ & $\begin{array}{c}\mathbf{2 ~ k W} \\
\text { night }\end{array}$ & $\begin{array}{c}\mathbf{6} \mathbf{k W} \\
\text { night }\end{array}$ & $\begin{array}{c}\mathbf{1 . 4} \mathbf{~ k W} \\
\text { evening }\end{array}$ & $\begin{array}{c}\mathbf{2} \mathbf{~ k W} \\
\text { evening }\end{array}$ & $\begin{array}{c}\mathbf{6} \mathbf{k W} \\
\text { evening }\end{array}$ \\
\hline $\mathbf{2 0 2 0}$ & & & & & & & & \\
Summer & 64.5 & 61.2 & 61.2 & 61.2 & 61.2 & 61.7 & 62.1 & 64.5 \\
Winter & 67.4 & 54.6 & 54.6 & 54.6 & 54.6 & 54.6 & 54.6 & 54.6 \\
Off-peak & 67.4 & 54.4 & 54.4 & 54.4 & 54.4 & 54.4 & 54.5 & 56.9 \\
\hline $\mathbf{2 0 3 0}$ & & & & & & & & \\
Summer & 79.3 & 74.2 & 74.2 & 74.2 & 74.2 & 76.5 & 78.3 & 84.4 \\
Winter & 82.2 & 66.1 & 66.1 & 66.1 & 66.1 & 66.1 & 66.1 & 66.1 \\
Off-peak & 82.2 & 65.9 & 65.9 & 65.9 & 65.9 & 66.7 & 68.3 & 74.4 \\
\hline
\end{tabular}

The region's generation mix consists of gas and coal, and to lesser extent nuclear, oil, and renewable technologies. There are clear differences in what plants are expected to satisfy the increased demand depending on the recharging pattern, and there are different patterns in 2020 and 2030 (Figure 28 and Figure 29). In 2020, night charging calls on mainly gas combined cycle, but as loads shift to the evening, gas turbines and oil capacity become more used. In 2030, the night scenarios use large amounts of coal, but this declines as load shifts to the evening, with gas turbines used more. All of the evening scenarios have unserved demands. In fact, there was unserved demand in all scenarios, it just increased in the evening scenarios. 


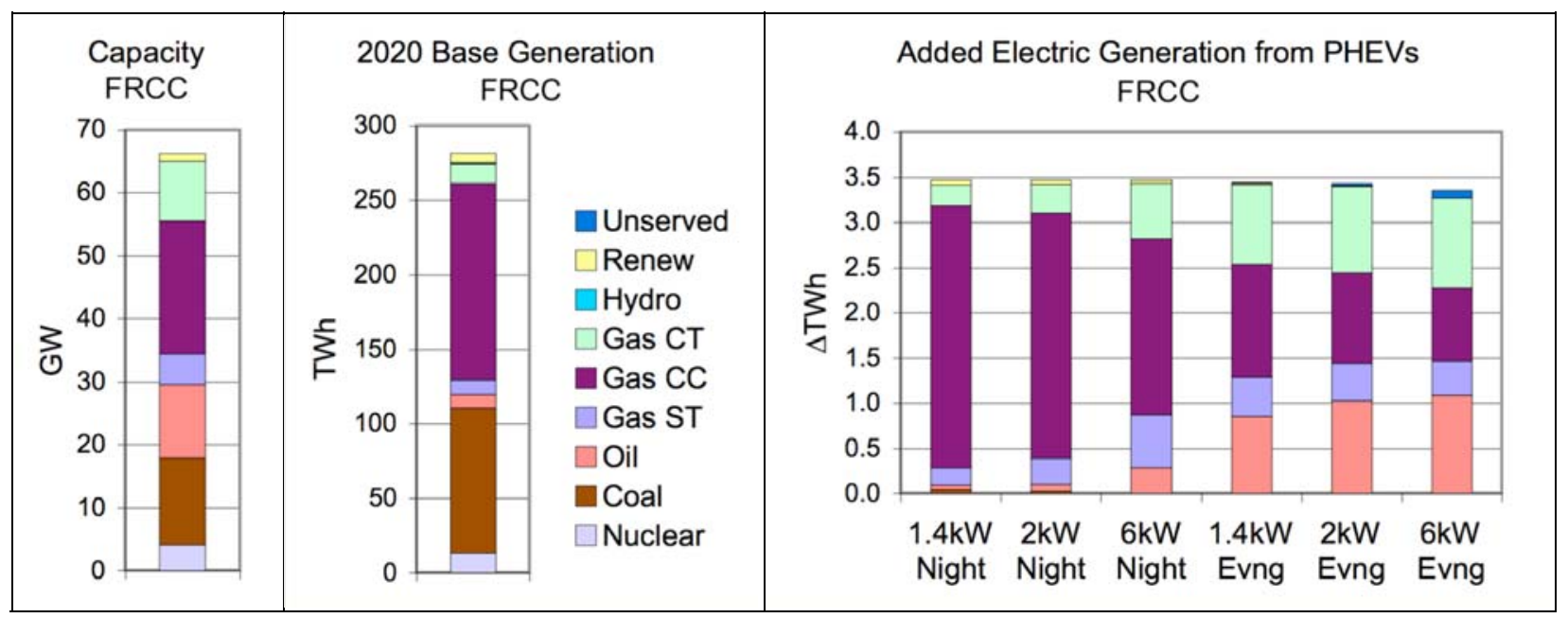

Figure 28. Projected 2020 generating capacity (left), base generation (center), and new generation dispatched to meet demand for each PHEV recharging scenario (right) for FRCC.

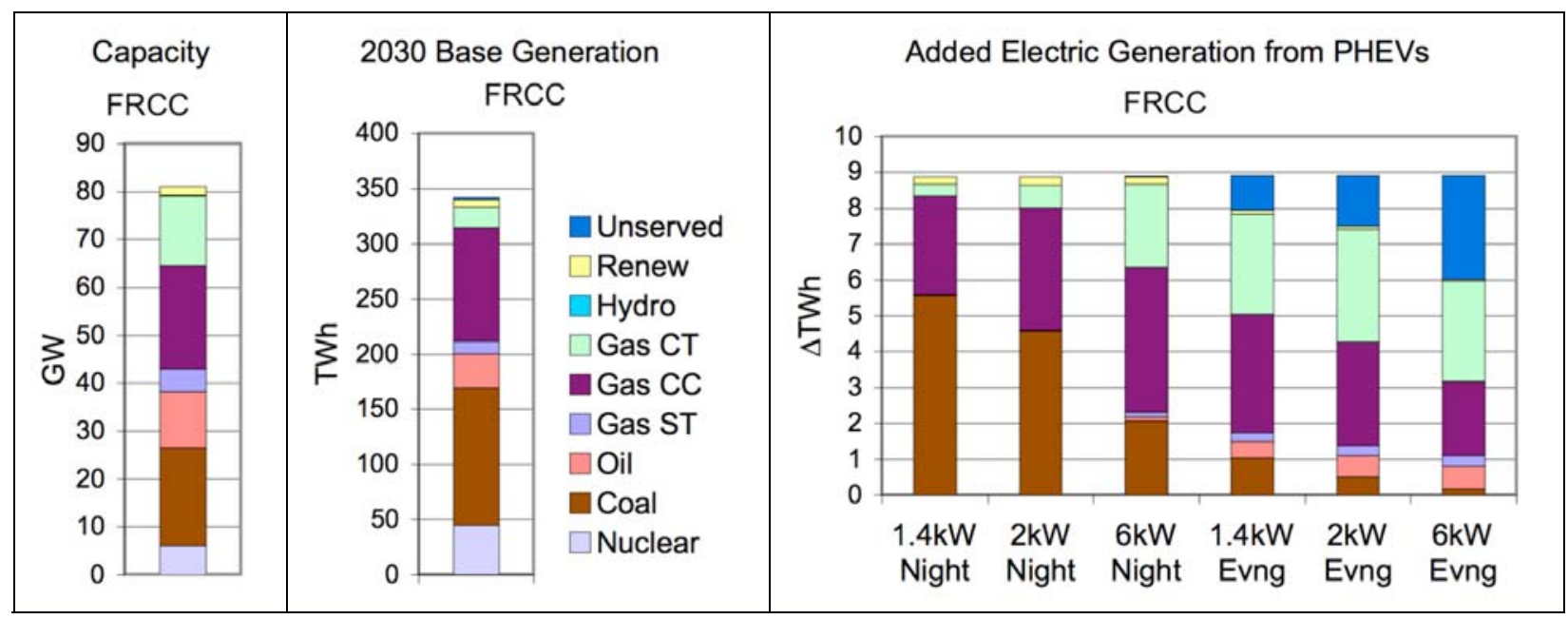

Figure 29. Projected 2030 generating capacity (left), base generation (center), and new generation dispatched to meet demand for each PHEV recharging scenario (right) for FRCC.

The generation, emissions, and cost factors in 2020 stayed relatively constant over the scenarios. Demand increased by $1.2 \%$ and the other factors increased gradually, with most staying under $2 \%$. Only the average price increased more, but only up to $8.5 \%$ (Table 33). In 2030, the PHEVs raised demand by $2.6 \%$, but because of lack of capacity, generation did not rise as much, especially for the evening scenarios. With the lesser generation, emissions in the evening scenarios were not as high as for the night scenarios. Costs and average prices were high to start with, and rose significantly as demands moved to the evening peak. 
Table 33. Generation, primary energy in, emissions, electricity prices, and PHEV charging costs in 2020 and 2030 for FRCC. Numbers in parentheses are percent change from no charging ("None").

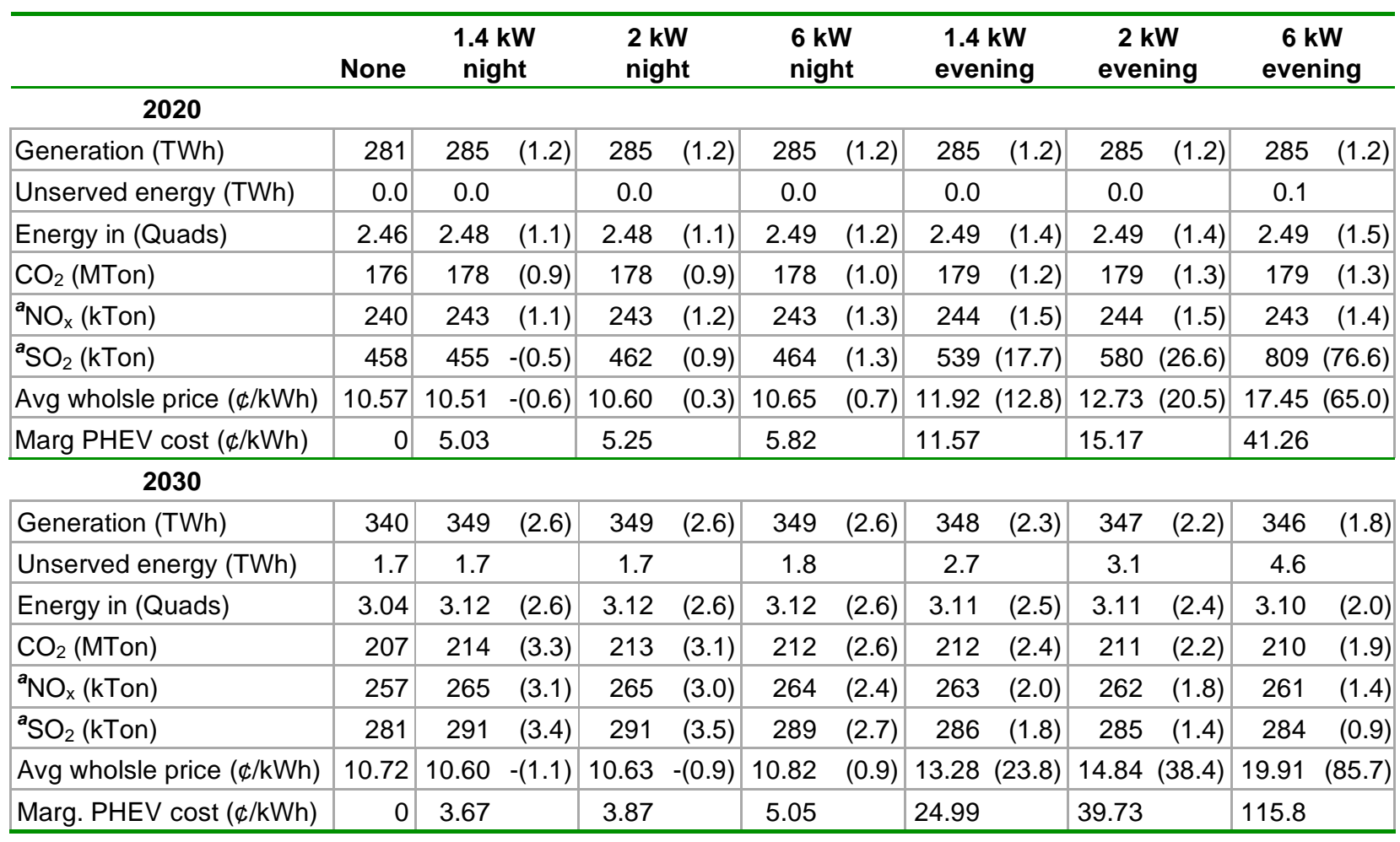

${ }^{a} \mathrm{NO}_{x}$ and $\mathrm{SO}_{2}$ emissions will be offset by reductions due to regulated caps.

The comparison between fuel use, emissions, and costs for the PHEVs in the region using gasoline versus electricity for 20 miles per day is shown in Table $34 . \mathrm{CO}_{2}$ emissions are significantly greater in 2030 than in 2020 . Much of the power for $20202 \mathrm{~kW}$ night charging is provided by combined cycle plants so $\mathrm{CO}_{2}$ emissions for that time are lower than for gasoline, but evening charging uses more turbines and oil capacity, which makes its emissions higher than for gasoline (Figure 28). By 2030, Annual Energy Outlook 2007 projects added coal capacity in FRCC, which plays a role in the night scenario (Figure 29). $\mathrm{NO}_{\mathrm{X}}$ and $\mathrm{SO}_{2}$ emissions are higher as well, but these will be offset by reductions elsewhere in the electric system because of the legal caps on total emissions. Costs are much lower with the PHEVs, except for the $2 \mathrm{~kW}$ evening scenario in 2030. In that scenario, the large amount of unserved energy raises the cost of production well above the cost of gasoline.

Table 34. Comparison of fuels, emissions, and costs for PHEVs using 2-kW recharging versus gasoline-fueled HEVs in FRCC, 2020 and 2030

\begin{tabular}{|c|c|c|c|c|c|c|}
\hline & \multicolumn{3}{|c|}{2020} & \multicolumn{3}{|c|}{2030} \\
\hline & \multirow[t]{2}{*}{$\begin{array}{c}\text { Gasoline- } \\
\text { fueled HEVs }\end{array}$} & \multicolumn{2}{|c|}{$\begin{array}{l}\text { PHEVs charged } \\
\text { from grid }\end{array}$} & \multirow[t]{2}{*}{$\begin{array}{c}\text { Gasoline- } \\
\text { fueled HEVs }\end{array}$} & \multicolumn{2}{|c|}{$\begin{array}{l}\text { PHEVs charged } \\
\text { from grid }\end{array}$} \\
\hline & & 2 kW Night & $\begin{array}{c}2 \mathrm{~kW} \\
\text { Evening }\end{array}$ & & 2 kW Night & $\begin{array}{c}2 \mathrm{~kW} \\
\text { Evening }\end{array}$ \\
\hline Vehicles (million) & 1.20 & & & 3.10 & & \\
\hline \multicolumn{7}{|l|}{ Fuel } \\
\hline - Oil (million barrel) & 5.2 & 0.1 & 2.0 & 13.5 & 0.0 & 1.5 \\
\hline
\end{tabular}




\begin{tabular}{|c|c|c|c|c|c|c|}
\hline & \multicolumn{3}{|c|}{2020} & \multicolumn{3}{|c|}{2030} \\
\hline & \multirow[t]{2}{*}{$\begin{array}{l}\text { Gasoline- } \\
\text { fueled HEVs }\end{array}$} & \multicolumn{2}{|c|}{$\begin{array}{l}\text { PHEVs charged } \\
\text { from grid }\end{array}$} & \multirow[t]{2}{*}{$\begin{array}{c}\text { Gasoline- } \\
\text { fueled HEVs }\end{array}$} & \multicolumn{2}{|c|}{$\begin{array}{l}\text { PHEVs charged } \\
\text { from grid }\end{array}$} \\
\hline & & 2 kW Night & $\begin{array}{c}2 \mathrm{~kW} \\
\text { Evening }\end{array}$ & & 2 kW Night & $\begin{array}{c}2 \mathrm{~kW} \\
\text { Evening }\end{array}$ \\
\hline - Coal (million ton) & & 0.01 & 0.00 & & 2.20 & 0.26 \\
\hline - Nat Gas (billion cuft) & & 26 & 23 & & 29 & 57 \\
\hline $\mathrm{CO}_{2}$ (million ton) & 2.1 & 1.6 & 2.3 & 5.5 & 6.4 & 4.6 \\
\hline${ }^{a} \mathrm{NO}_{\mathrm{x}}$ (thousand ton) & 0.5 & 2.8 & 3.6 & 1.2 & 7.7 & 4.6 \\
\hline${ }^{a} \mathrm{SO}_{2}$ (thousand ton) & 0 & 4 & 122 & & 10 & 4 \\
\hline${ }^{b}$ Cost (\$million) & 659 & 182 & 526 & 1,695 & 346 & 3,545 \\
\hline
\end{tabular}

${ }^{a} \mathrm{NO}_{\mathrm{x}}$ and $\mathrm{SO}_{2}$ emissions will be offset by reductions due to regulated caps.

${ }^{b}$ This comparison does not include the added vehicle cost for PHEV batteries or recharging capability, nor the full retail price of electricity.

\subsection{Southeastern Electric Reliability Council (SERC)}

The model predicts the SERC region's peak load capacity to be $237 \mathrm{GW}$ in 2020 and $276 \mathrm{GW}$ in 2030 (Table 35). In the case of night recharge, the introduction of PHEVs does not affect summer peak values, but evening recharging increases the peak up to $213 \mathrm{GW}$ in 2020 and 266 $\mathrm{GW}$ in 2030. So even with evening recharging, planned capacity appears to be sufficient to meet peak demand. However, due to outages, additional capacity would still be needed to meet reserve requirements.

Table 35. Capacity and peak demand in each season under each charging scenario for 2020 and 2030 in SERC (GW)

\begin{tabular}{|c|c|c|c|c|c|c|c|c|}
\hline & Capacity & $\begin{array}{c}\text { No } \\
\text { charging }\end{array}$ & $\begin{array}{c}1.4 \mathrm{~kW} \\
\text { night }\end{array}$ & $\begin{array}{l}2 \text { kW } \\
\text { night }\end{array}$ & $\begin{array}{l}6 \mathrm{~kW} \\
\text { night }\end{array}$ & $\begin{array}{c}1.4 \mathrm{~kW} \\
\text { evening }\end{array}$ & $\begin{array}{c}2 \mathrm{~kW} \\
\text { evening }\end{array}$ & $\begin{array}{c}6 \mathrm{~kW} \\
\text { evening }\end{array}$ \\
\hline \multicolumn{9}{|l|}{2020} \\
\hline Summer & 236.6 & 206.9 & 206.9 & 206.9 & 206.9 & 206.9 & 206.9 & 213.3 \\
\hline Winter & 245.6 & 181.5 & 181.6 & 181.5 & 181.5 & 181.5 & 181.5 & 181.5 \\
\hline Off-peak & 245.6 & 157.5 & 157.5 & 157.5 & 157.5 & 157.5 & 157.7 & 164.5 \\
\hline \multicolumn{9}{|l|}{2030} \\
\hline Summer & 276.1 & 240.5 & 240.5 & 240.5 & 240.5 & 244.2 & 249.4 & 266.4 \\
\hline Winter & 285.2 & 210.9 & 211.2 & 210.9 & 210.9 & 210.9 & 212.3 & 228.4 \\
\hline Off-peak & 285.2 & 183.1 & 183.1 & 183.1 & 184.6 & 187.4 & 192.6 & 209.2 \\
\hline
\end{tabular}

The electricity generation in the SERC region is based predominantly on coal and nuclear, with small contributions from gas and hydro technologies (Figure 30 and Figure 31). The model predicts that the introduction of PHEVs will increase coal and gas generation in the proportions dependent on the alternative analyzed. As the charging power level increases and moves towards peak periods, the share of coal decreases and gas increases. If PHEVs are recharged in the evenings, the change in demand is predicted to be satisfied chiefly by gas combined cycle and combustion turbine plants. 


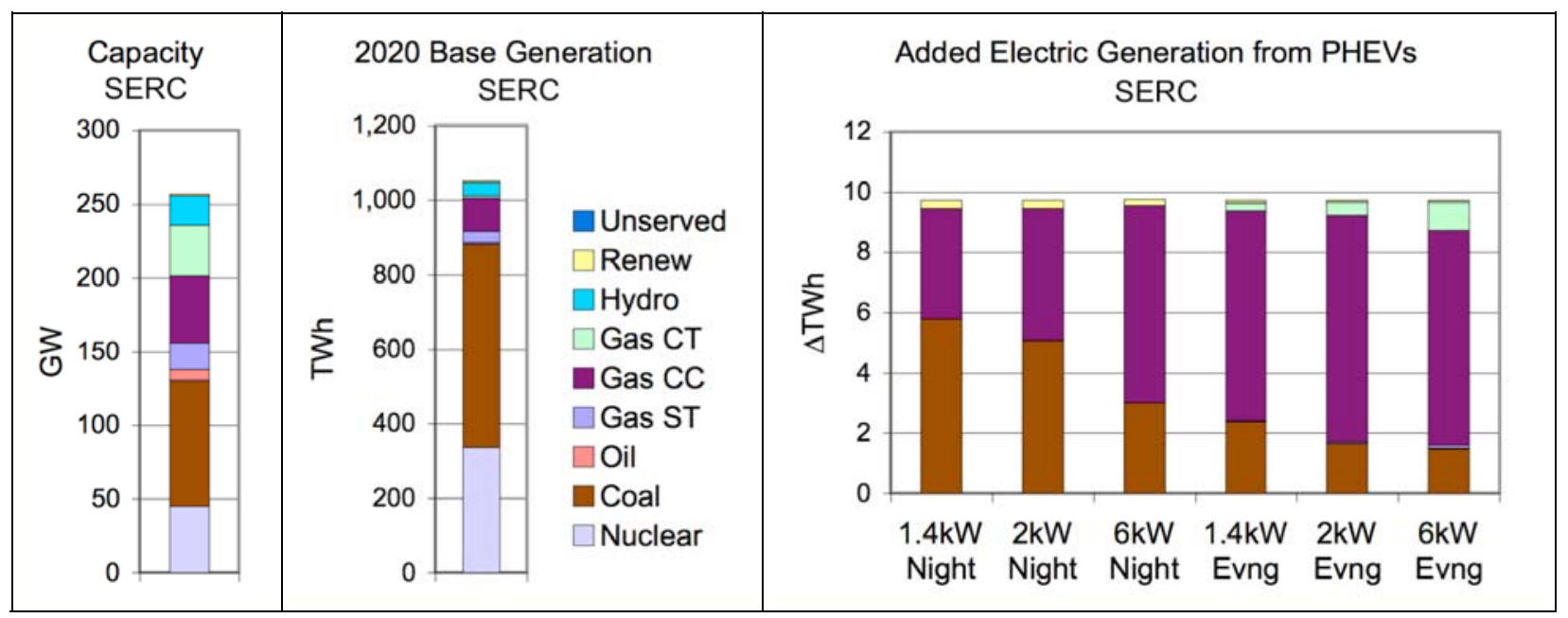

Figure 30. Projected 2020 generating capacity (left), base generation (center), and new generation dispatched to meet demand for each PHEV recharging scenario (right) for SERC.

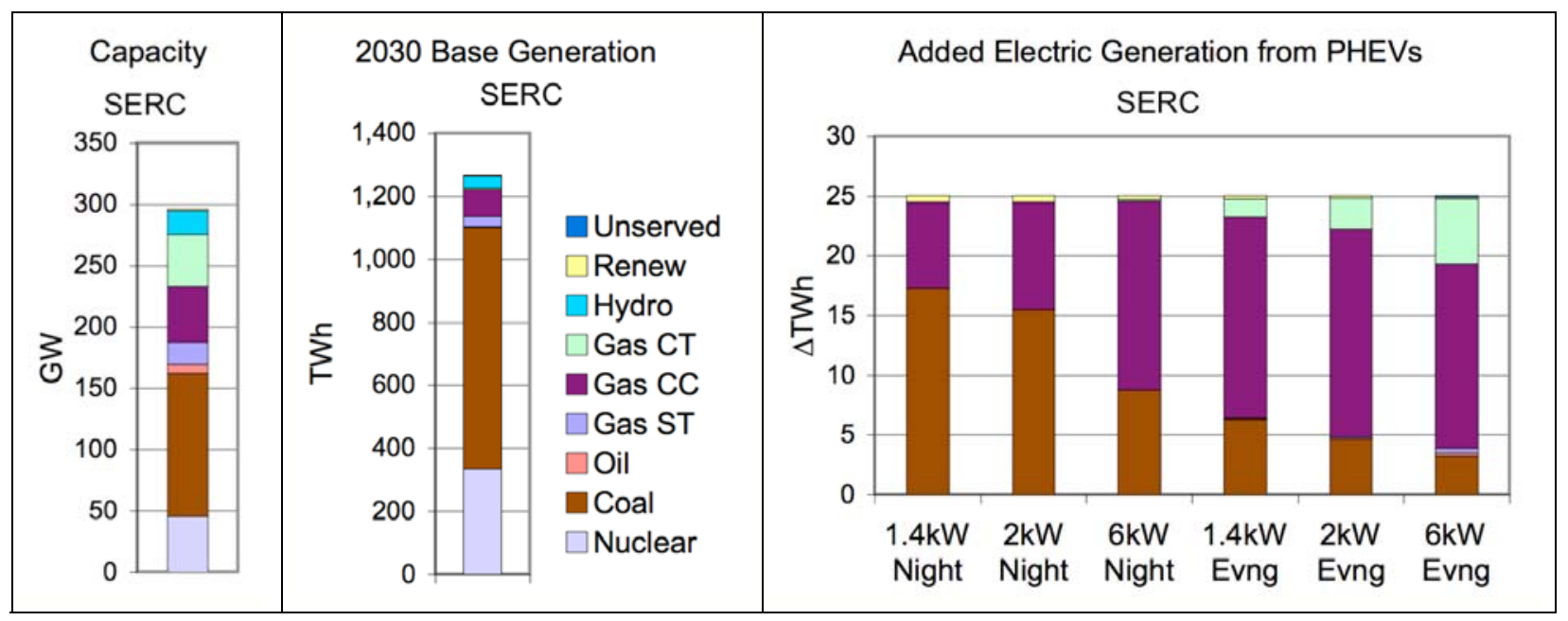

Figure 31. Projected 2030 generating capacity (left), base generation (center), and new generation dispatched to meet demand for each PHEV recharging scenario (right) for SERC.

SERC generation grows by $0.9 \%$ in 2020 and $2 \%$ in 2030 in response to PHEV charging (Table 36). Prices and emissions levels are somewhat sensitive to the recharging pattern chosen by the hybrid owners. The region still is likely to experience some shortage of generating capacity if 6 $\mathrm{kW}$ PHEVs are plugged in during the peak hours, though this shortage is modest compared to other regions. The emissions levels are smaller if recharging occurs in the evenings. Under the night recharge pattern the price increments get smaller as the battery power capacity increases. Under the evening recharge scenario the price increases. 
Table 36. Generation, primary energy in, emissions, electricity prices, and PHEV charging costs in 2020 and 2030 for SERC. Numbers in parentheses are percent change from no charging ("None").

\begin{tabular}{|c|c|c|c|c|c|c|c|c|c|c|c|c|c|}
\hline & \multicolumn{3}{|c|}{$\begin{array}{c}1.4 \mathrm{~kW} \\
\text { night }\end{array}$} & \multicolumn{2}{|c|}{$\begin{array}{l}2 \mathrm{~kW} \\
\text { night }\end{array}$} & \multicolumn{2}{|c|}{$\begin{array}{l}6 \mathrm{~kW} \\
\text { night }\end{array}$} & \multicolumn{2}{|c|}{$\begin{array}{l}1.4 \mathrm{~kW} \\
\text { evening }\end{array}$} & \multicolumn{2}{|c|}{$\begin{array}{c}2 \mathrm{~kW} \\
\text { evening }\end{array}$} & \multicolumn{2}{|c|}{$\begin{array}{c}6 \mathrm{~kW} \\
\text { evening }\end{array}$} \\
\hline Generation (TWh) & 1,053 & 1,063 & $(0.9)$ & 1,063 & $(0.9)$ & 1,063 & $(0.9)$ & 1,063 & $(0.9)$ & 1,063 & $(0.9)$ & 1,063 & $(0.9)$ \\
\hline Unserved energy (TWh) & 0.0 & 0.0 & & 0.0 & & 0.0 & & 0.0 & & 0.0 & & 0.0 & \\
\hline Energy in (Quads) & 10.44 & 10.54 & $(0.9)$ & 10.53 & $(0.9)$ & 10.53 & $(0.8)$ & 10.53 & $(0.8)$ & 10.52 & $(0.8)$ & 10.53 & $(0.8)$ \\
\hline $\mathrm{CO}_{2}$ (MTon) & 637 & 645 & $(1.2)$ & 645 & $(1.2)$ & 643 & $(1.0)$ & 643 & $(0.9)$ & 643 & $(0.9)$ & 643 & $(0.9)$ \\
\hline${ }^{a} \mathrm{NO}_{\mathrm{x}}$ (kTon) & 562 & 574 & $(2.1)$ & 573 & $(1.9)$ & 569 & $(1.2)$ & 569 & $(1.2)$ & 568 & $(1.0)$ & 568 & $(1.0)$ \\
\hline${ }^{a} \mathrm{SO}_{2}$ (kTon) & 2,051 & 2,100 & $(2.4)$ & 2,095 & $(2.2)$ & 2,078 & $(1.3)$ & 2,073 & $(1.1)$ & 2,067 & $(0.8)$ & 2,066 & $(0.7)$ \\
\hline Avg wholsle price (\$/kWh) & 4.51 & 4.55 & $(1.0)$ & 4.56 & $(1.1)$ & 4.53 & $(0.6)$ & 4.54 & $(0.8)$ & 4.55 & $(1.0)$ & 4.59 & $(1.8)$ \\
\hline Marg PHEV cost (\$/kWh) & 0 & 3.65 & & 3.77 & & 4.25 & & 4.34 & & 4.40 & & 4.71 & \\
\hline \multicolumn{14}{|l|}{2030} \\
\hline Generation (TWh) & 1,268 & 1,294 & $(2.0)$ & 1,294 & $(2.0)$ & 1,294 & $(2.0)$ & 1,294 & $(2.0)$ & 1,294 & $(2.0)$ & 1,293 & (2.0) \\
\hline Unserved energy (TWh) & 0.0 & 0.0 & & 0.0 & & 0.0 & & 0.0 & & 0.0 & & 0.2 & \\
\hline Energy in (Quads) & 12.25 & 12.49 & $(2.0)$ & 12.49 & $(1.9)$ & 12.46 & $(1.7)$ & 12.46 & $(1.7)$ & 12.46 & $(1.7)$ & 12.47 & $(1.8)$ \\
\hline $\mathrm{CO}_{2}$ (MTon) & 827 & 849 & $(2.6)$ & 848 & $(2.5)$ & 843 & $(2.0)$ & 842 & $(1.8)$ & 841 & $(1.7)$ & 841 & $(1.7)$ \\
\hline${ }^{a} \mathrm{NO}_{\mathrm{x}}(\mathrm{kTon})$ & 630 & 660 & $(4.8)$ & 658 & $(4.4)$ & 648 & $(2.9)$ & 647 & (2.7) & 647 & $(2.7)$ & 647 & (2.7) \\
\hline${ }^{a} \mathrm{SO}_{2}$ (kTon) & 1,902 & 2,035 & $(7.0)$ & 2,022 & $(6.3)$ & 1,971 & (3.7) & 1,955 & $(2.8)$ & 1,944 & $(2.2)$ & 1,934 & $(1.7)$ \\
\hline Avg wholsle price (\$/kWh) & 4.37 & 4.46 & $(2.1)$ & 4.45 & $(2.0)$ & 4.43 & $(1.4)$ & 4.48 & $(2.5)$ & 4.52 & (3.6) & 4.77 & $(9.1)$ \\
\hline Marg. PHEV cost ( $\$ / k W h)$ & 0 & 3.90 & & 3.96 & & 4.06 & & 4.36 & & 4.58 & & 5.54 & \\
\hline
\end{tabular}

${ }^{a} \mathrm{NO}_{\mathrm{x}}$ and $\mathrm{SO}_{2}$ emissions will be offset by reductions due to regulated caps.

The comparison between the fuel use, emissions, and cost for PHEVs in the region using gasoline versus electricity for the 20 miles per day is shown in Table $37 . \mathrm{CO}_{2}$ emissions are higher for charging than for gasoline in the night scenarios because of the high amount of coal use, but are lower for evening charging because generation has shifted to combined cycle plants (Figure 30). $\mathrm{NO}_{\mathrm{X}}$ and $\mathrm{SO}_{2}$ emissions are higher, but these will be offset by reductions elsewhere in the electric system because of the legal caps on total emissions. Costs are much lower with the PHEVs, less than a third of the gasoline cost. Even if customer prices are triple what is shown in Table 36 the customer would save money, and so likely would save money charging even at peak times.

Table 37. Comparison of fuels, emissions, and costs for PHEVs using 2-kW recharging versus gasoline-fueled HEVs in SERC, 2020 and 2030

\begin{tabular}{|c|c|c|c|c|c|c|}
\hline & \multicolumn{3}{|c|}{2020} & \multicolumn{3}{|c|}{2030} \\
\hline & \multirow[t]{2}{*}{$\begin{array}{c}\text { Gasoline- } \\
\text { fueled HEVs }\end{array}$} & \multicolumn{2}{|c|}{$\begin{array}{l}\text { PHEVs charged } \\
\text { from grid }\end{array}$} & \multirow[t]{2}{*}{$\begin{array}{c}\text { Gasoline- } \\
\text { fueled HEVs }\end{array}$} & \multicolumn{2}{|c|}{$\begin{array}{l}\text { PHEVs charged } \\
\text { from grid }\end{array}$} \\
\hline & & 2 kW night & 2 kW evening & & $2 \mathrm{~kW}$ night & $2 \mathrm{~kW}$ evening \\
\hline Vehicles (million) & 3.38 & & & 8.70 & & \\
\hline \multicolumn{7}{|l|}{ Fuel } \\
\hline - Oil (million barrel) & 14.7 & 0.0 & 0.0 & 37.8 & 0.0 & 0.1 \\
\hline - Coal (million ton) & & 2.64 & 0.89 & & 7.97 & 2.48 \\
\hline - Nat Gas (billion cuft) & & 31 & 59 & & 64 & 151 \\
\hline $\mathrm{CO}_{2}$ (million ton) & 6.0 & 7.5 & 5.4 & 15.4 & 20.7 & 14.3 \\
\hline
\end{tabular}




\begin{tabular}{|c|c|c|c|c|c|c|}
\hline & \multicolumn{3}{|c|}{2020} & \multicolumn{3}{|c|}{2030} \\
\hline & \multirow[t]{2}{*}{$\begin{array}{c}\text { Gasoline- } \\
\text { fueled HEVs }\end{array}$} & \multicolumn{2}{|c|}{$\begin{array}{l}\text { PHEVs charged } \\
\text { from grid }\end{array}$} & \multirow[t]{2}{*}{$\begin{array}{l}\text { Gasoline- } \\
\text { fueled HEVs }\end{array}$} & \multicolumn{2}{|c|}{$\begin{array}{l}\text { PHEVs charged } \\
\text { from grid }\end{array}$} \\
\hline & & 2 kW night & 2 kW evening & & 2 kW night & $2 \mathrm{~kW}$ evening \\
\hline${ }^{a} \mathrm{NO}_{\mathrm{x}}$ (thousand ton) & 1.4 & 10.8 & 5.6 & 3.5 & 27.9 & 17.0 \\
\hline${ }^{a} \mathrm{SO}_{2}$ (thousand ton) & 0 & 44 & 16 & & 121 & 42 \\
\hline${ }^{b}$ Cost (\$million) & 1,850 & 367 & 428 & 4,761 & 993 & 1,147 \\
\hline
\end{tabular}

${ }^{a} \mathrm{NO}_{x}$ and $\mathrm{SO}_{2}$ emissions will be offset by reductions due to regulated caps.

${ }^{b}$ This comparison does not include the added vehicle cost for PHEV batteries or recharging capability, nor the full retail price of electricity.

\subsection{Southwest Power Pool (SPP)}

The Southwest Power Pool is one of the regions where there are relatively large margins between demand and capacity under the scenarios considered. The model predicts generating capacity of 66.9 GW for SPP in 2030. PHEVs in this region do not affect peak load values if recharged at night (Table 38). In this case, demand is expected to be $48.6 \mathrm{GW}$ in 2020 and $55 \mathrm{GW}$ in 2030. The hybrids' market penetration would improve generating capacity utilization in the area without raising any electricity supply related concerns. The evening recharging scenario may produce demand as high as $58.2 \mathrm{GW}$, which is still much lower than the SPP capacity.

Table 38. Capacity and peak demand in each season under each scenario for 2020 and 2030 in SPP (GW)

\begin{tabular}{|c|c|c|c|c|c|c|c|c|}
\hline & Capacity & $\begin{array}{c}\text { No } \\
\text { charging }\end{array}$ & $\begin{array}{c}1.4 \mathrm{~kW} \\
\text { night }\end{array}$ & $\begin{array}{l}2 \mathrm{~kW} \\
\text { night }\end{array}$ & $\begin{array}{l}6 \mathrm{~kW} \\
\text { night }\end{array}$ & $\begin{array}{c}1.4 \mathrm{~kW} \\
\text { evening }\end{array}$ & $\begin{array}{c}2 \mathrm{~kW} \\
\text { evening }\end{array}$ & $\begin{array}{c}6 \mathrm{~kW} \\
\text { evening }\end{array}$ \\
\hline \multicolumn{9}{|l|}{2020} \\
\hline Summer & 58.9 & 48.6 & 48.6 & 48.6 & 48.6 & 48.6 & 48.6 & 49.2 \\
\hline Winter & 60.2 & 37.6 & 37.6 & 37.6 & 37.6 & 38.0 & 38.3 & 39.1 \\
\hline Off-peak & 60.2 & 40.5 & 40.5 & 40.5 & 40.5 & 40.5 & 40.6 & 41.5 \\
\hline \multicolumn{9}{|l|}{2030} \\
\hline Summer & 66.9 & 55.4 & 55.4 & 55.4 & 55.4 & 55.6 & 55.9 & 58.2 \\
\hline Winter & 68.2 & 42.9 & 42.9 & 42.9 & 42.9 & 44.3 & 45.0 & 47.2 \\
\hline Off-peak & 68.2 & 46.3 & 46.3 & 46.3 & 46.3 & 46.7 & 47.2 & 49.4 \\
\hline
\end{tabular}

The electric generation in the SPP region is mainly based on coal and gas to a lesser extent, with a negligible share of renewable and hydropower (Figure 32 and Figure 33). The model predicts that gas combined cycle plants will mainly satisfy the increased demand if recharging occurs at night, with other gas technologies increasing as more power is required for evening charging. Conversely, the coal share shrinks as the battery power level increases and more power is called for during peak times. A small amount generation from oil-fired technologies also comes on line during the evening charging scenarios. 


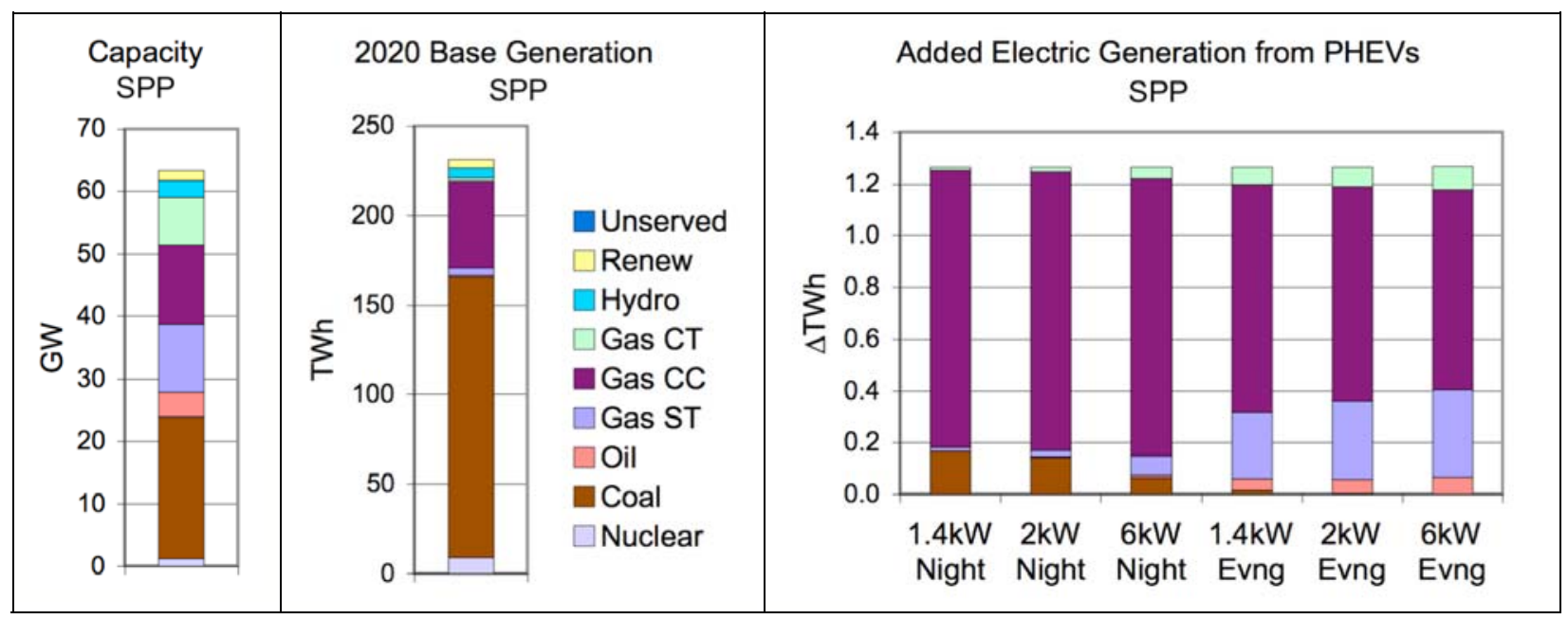

Figure 32. Projected 2020 generating capacity (left), base generation (center), and new generation dispatched to meet demand for each PHEV recharging scenario (right) for SPP.

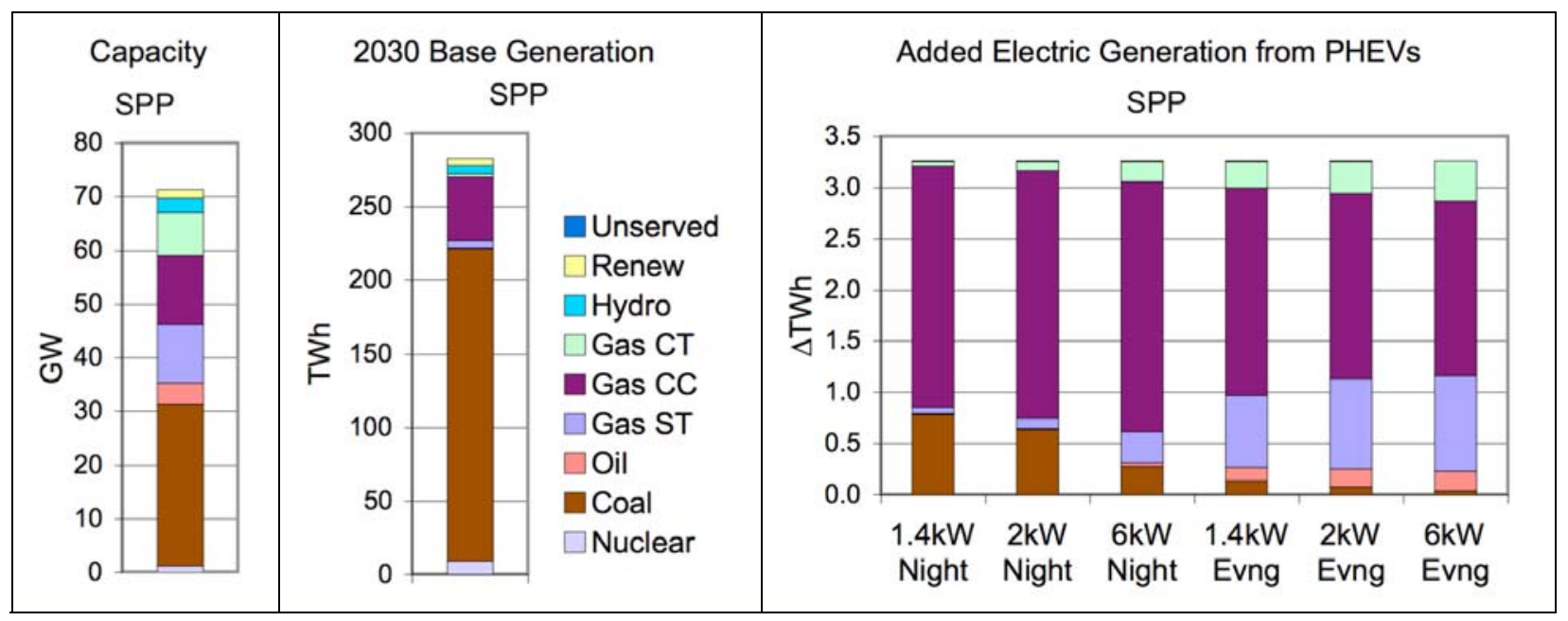

Figure 33. Projected 2030 generating capacity (left), base generation (center), and new generation dispatched to meet demand for each PHEV recharging scenario (right) for SPP.

The generation, price, and emissions indicators for the SPP region are not particularly sensitive to the scenario analyzed. As in the other regions, electricity price is the most sensitive statistic, yet it is expected to go up by no more than $2.2 \%$ (from 4.74 to 5.58 cents per $\mathrm{kWh}$ in 2030 ) (Table 39). All other indicators increase by no more than $1.1 \%$. 
Table 39. Generation, primary energy in, emissions, electricity prices, and PHEV charging costs in 2020 and 2030 for SPP. Numbers in parentheses are percent change from no charging ("None").

\begin{tabular}{|c|c|c|c|c|c|c|c|c|c|c|c|c|c|}
\hline & \multirow[t]{2}{*}{ None } & \multicolumn{2}{|c|}{$\begin{array}{c}1.4 \mathrm{~kW} \\
\text { night }\end{array}$} & \multicolumn{2}{|c|}{$\begin{array}{l}2 \mathrm{~kW} \\
\text { night }\end{array}$} & \multicolumn{2}{|c|}{$\begin{array}{l}6 \mathrm{~kW} \\
\text { night }\end{array}$} & \multicolumn{2}{|c|}{$\begin{array}{c}1.4 \mathrm{~kW} \\
\text { evening }\end{array}$} & \multicolumn{2}{|c|}{$\begin{array}{c}2 \mathrm{~kW} \\
\text { evening }\end{array}$} & \multicolumn{2}{|c|}{$\begin{array}{c}6 \mathrm{~kW} \\
\text { evening }\end{array}$} \\
\hline \multicolumn{13}{|l|}{2020} & \\
\hline Generation (TWh) & 231 & 232 & $(0.5)$ & 232 & $(0.5)$ & 232 & $(0.5)$ & 232 & $(0.5)$ & 232 & $(0.5)$ & 232 & $(0.5)$ \\
\hline Unserved energy ( $T$ & 0.0 & 0.0 & & 0.0 & & 0.0 & & 0.0 & & 0.0 & & 0.0 & \\
\hline Energy in (Quads) & 2.29 & 2.30 & $(0.4)$ & 2.30 & $(0.4)$ & 2.30 & $(0.4)$ & 2.30 & $(0.5)$ & 2.30 & $(0.5)$ & 2.30 & $(0.5)$ \\
\hline $\mathrm{CO}_{2}$ (MTon) & 199 & 200 & $(0.3)$ & 200 & $(0.3)$ & 200 & $(0.3)$ & 200 & $(0.3)$ & 200 & $(0.3)$ & 200 & $(0.3)$ \\
\hline $\mathrm{NO}_{\mathrm{x}}$ (kTon) & 291 & 291 & $(0.2)$ & 291 & $(0.2)$ & 291 & $(0.2)$ & 291 & $(0.2)$ & 291 & $(0.3)$ & 291 & $(0.3)$ \\
\hline${ }^{a} \mathrm{SO}_{2}$ (kTon) & 19 & 420 & $(0.2)$ & 420 & $(0.2)$ & 419 & $(0.1)$ & 419 & $(0.1)$ & 419 & $(0.1)$ & 20 & $(0.1)$ \\
\hline Avg wholsle price ( & 4.89 & 4.91 & $(0.4)$ & 4.91 & $(0.4)$ & 4.92 & $(0.5)$ & 4.92 & $(0.6)$ & 4.93 & $(0.8)$ & 4.93 & $(0.7)$ \\
\hline Marg PHEV cost & 0 & 4.19 & & 4.25 & & 4.50 & & 5.07 & & 5.25 & & 5.46 & \\
\hline \multicolumn{14}{|l|}{2030} \\
\hline Generation (TWh) & 83 & 286 & $(1.2)$ & 286 & $(1.2)$ & 286 & $(1.2)$ & 286 & $(1.2)$ & 286 & $(1.2)$ & 286 & $(1.2)$ \\
\hline Unserved $\epsilon$ & & 0.0 & & 0.0 & & 0.0 & & 0.0 & & 0.0 & & 0.0 & \\
\hline Energy in (Quads) & 2.73 & 2.76 & (1.0) & 2.76 & $(1.0)$ & 2.76 & $(1.0)$ & 2.76 & $(1.0)$ & 2.76 & (1.1) & 2.76 & $(1.1)$ \\
\hline $\mathrm{CO}_{2}$ (MTon) & 247 & 249 & $(0.8)$ & 249 & $(0.8)$ & 248 & $(0.7)$ & 249 & $(0.7)$ & 249 & $(0.7)$ & 249 & $(0.7)$ \\
\hline${ }^{a} \mathrm{NO}_{\mathrm{x}}$ (kTon) & 311 & 313 & $(0.8)$ & 313 & $(0.7)$ & 312 & $(0.6)$ & 313 & $(0.7)$ & 313 & $(0.7)$ & 313 & $(0.7)$ \\
\hline${ }^{a} \mathrm{SO}_{2}$ (kTon) & 415 & 418 & $(0.8)$ & 418 & $(0.7)$ & 416 & $(0.4)$ & 416 & $(0.4)$ & 416 & $(0.4)$ & 416 & $(0.4)$ \\
\hline Avg wholsle price (\$/kWh) & 4.74 & 4.81 & (1.3) & 4.82 & $(1.5)$ & 4.82 & (1.5) & 4.83 & (1.8) & 4.84 & $(2.1)$ & 4.85 & (2.2) \\
\hline Marg. PHEV cost (\$/kWh) & 0 & 3.97 & & 4.09 & & 4.53 & & 5.06 & & 5.32 & & 5.58 & \\
\hline
\end{tabular}

${ }^{a} \mathrm{SO}_{2}$ emissions will be offset by reductions due to regulated caps.

The comparison between fuel use, emissions, and costs for the PHEVs in the region using gasoline versus electricity for the 20 miles per day is shown in Table 40. Because of the high amount of gas use for the PHEV generation in SPP (Figure 32), $\mathrm{CO}_{2}$ emissions are lower with PHEVs than with efficient HEVs. $\mathrm{NO}_{\mathrm{X}}$ and $\mathrm{SO}_{2}$ emissions are higher, but the $\mathrm{SO}_{2}$ will be offset by reductions elsewhere in the electric system because of the legal caps on total emissions. Costs are much lower with the PHEVs, less than a third of the gasoline cost. Even if customer prices are triple from what is shown in Table 39 the customer would save money, and so likely would save money charging even at peak times.

Table 40. Comparison of fuels, emissions, and costs for PHEVs using 2-kW recharging versus gasoline-fueled HEVs in SPP, 2020 and 2030

\begin{tabular}{|c|c|c|c|c|c|c|}
\hline & \multicolumn{3}{|c|}{2020} & \multicolumn{3}{|c|}{2030} \\
\hline & \multirow[t]{2}{*}{$\begin{array}{c}\text { Gasoline- } \\
\text { fueled HEVs }\end{array}$} & \multicolumn{2}{|c|}{$\begin{array}{l}\text { PHEVs charged } \\
\text { from grid }\end{array}$} & \multirow[t]{2}{*}{$\begin{array}{c}\text { Gasoline- } \\
\text { fueled HEVs }\end{array}$} & \multicolumn{2}{|c|}{$\begin{array}{l}\text { PHEVs charged } \\
\text { from grid }\end{array}$} \\
\hline & & $2 \mathrm{~kW}$ night & $2 \mathrm{~kW}$ evening & & $2 \mathrm{~kW}$ night & $2 \mathrm{~kW}$ evening \\
\hline Vehicles (million) & 0.44 & & & 1.13 & & \\
\hline \multicolumn{7}{|l|}{ Fuel } \\
\hline - Oil (million barrel) & 1.9 & 0.0 & 0.1 & 4.9 & 0.0 & 0.4 \\
\hline - Coal (million ton) & & 0.09 & 0.00 & & 0.37 & 0.05 \\
\hline - Nat Gas (billion cuft) & & 8 & 10 & & 19 & 26 \\
\hline $\mathrm{CO}_{2}$ (million ton) & 0.8 & 0.7 & 0.7 & 2.0 & 1.9 & 1.8 \\
\hline $\mathrm{NO}_{\mathrm{x}}$ (thousand ton) & 0.2 & 0.6 & 0.8 & 0.5 & 2.2 & 2.1 \\
\hline
\end{tabular}




\begin{tabular}{|c|c|c|c|c|c|c|}
\hline & \multicolumn{3}{|c|}{2020} & \multicolumn{3}{|c|}{2030} \\
\hline & \multirow[t]{2}{*}{$\begin{array}{c}\text { Gasoline- } \\
\text { fueled HEVs }\end{array}$} & \multicolumn{2}{|c|}{$\begin{array}{l}\text { PHEVs charged } \\
\text { from grid }\end{array}$} & \multirow[t]{2}{*}{$\begin{array}{c}\text { Gasoline- } \\
\text { fueled HEVs }\end{array}$} & \multicolumn{2}{|c|}{$\begin{array}{l}\text { PHEVs charged } \\
\text { from grid }\end{array}$} \\
\hline & & night & $2 \mathrm{~kW}$ evening & & $2 \mathrm{~kW}$ night & $2 \mathrm{~kW}$ evening \\
\hline${ }^{a} \mathrm{SO}_{2}$ (thousand ton) & 0 & 1 & 0 & & 3 & 2 \\
\hline${ }^{b}$ Cost (\$million) & 240 & 54 & 66 & 619 & 133 & 173 \\
\hline
\end{tabular}

${ }^{a} \mathrm{SO}_{2}$ emissions will be offset by reductions due to regulated caps.

${ }^{b}$ This comparison does not include the added vehicle cost for PHEV batteries or recharging capability, nor the full retail price of electricity.

\subsection{Western Electricity Coordinating Council - Northwest Power Pool Area (WECC - NW)}

The WECC-NW region has enough generation capacity (74.1 GW in 2030) to satisfy the PHEVcreated demand for any recharging pattern. If PHEVs are plugged in at night the demand would go up 52.3 GW in the summer and $58 \mathrm{GW}$ in the winter (peak demand for the region is in winter). The peak values are not affected and the valleys in the load curves get partly filled by the newly created electricity demand (Table 41). If hybrids are charged in the evening, it peaks at $68 \mathrm{GW}$, still below the region's capacity. The 2020 peaks are also below the available capacity.

Table 41. Capacity and peak demand in each season under each scenario for 2020 and 2030 in WECC-NW (GW)

\begin{tabular}{cccccc|ccc}
\hline & Capacity & $\begin{array}{c}\text { No } \\
\text { charging }\end{array}$ & $\begin{array}{c}\mathbf{1 . 4} \mathbf{~ k W} \\
\text { night }\end{array}$ & $\begin{array}{c}\mathbf{2 ~ k W} \\
\text { night }\end{array}$ & $\begin{array}{c}\mathbf{6} \mathbf{~ k W} \\
\text { night }\end{array}$ & $\begin{array}{c}\mathbf{1 . 4} \mathbf{~ k W} \\
\text { evening }\end{array}$ & $\begin{array}{c}\mathbf{2 ~ k W} \\
\text { evening }\end{array}$ & $\begin{array}{c}\mathbf{6} \mathbf{~ k W} \\
\text { evening }\end{array}$ \\
\hline $\begin{array}{c}\mathbf{2 0 2 0} \\
\text { Summer }\end{array}$ & 64.9 & 45.9 & 45.9 & 45.9 & 45.9 & 46.4 & 47.0 & 49.0 \\
Winter & 65.7 & 50.9 & 50.9 & 50.9 & 50.9 & 52.1 & 52.7 & 54.7 \\
Off-peak & 65.7 & 47.3 & 47.3 & 47.3 & 47.3 & 48.8 & 49.4 & 51.4 \\
\hline $\mathbf{2 0 3 0}$ & & & & & & & & \\
Summer & 74.1 & 52.3 & 52.3 & 52.3 & 52.3 & 54.8 & 56.4 & 61.6 \\
Winter & 74.9 & 58.0 & 58.0 & 58.0 & 58.0 & 61.4 & 63.0 & 68.2 \\
Off-peak & 74.9 & 54.1 & 54.1 & 54.1 & 54.1 & 57.9 & 59.5 & 64.7 \\
\hline
\end{tabular}

In 2030 the WECC-NW region's generation mix is unique in the large amount of hydro production. Other supplies are coal plus some combined cycle and renewable (Figure 34 and Figure 35). Because of the large amount of hydro, demand from PHEVs at specific hours is counteracted by a shifting of the hydro production to optimize overall generation. This leads to each charging scenario having the same mix of plants producing the required generation. In 2020 the mix is largely combined cycle, plus some gas-fired steam plants and combustion turbines. In 2030, the marginal production is combined cycle and some renewable capacity. 


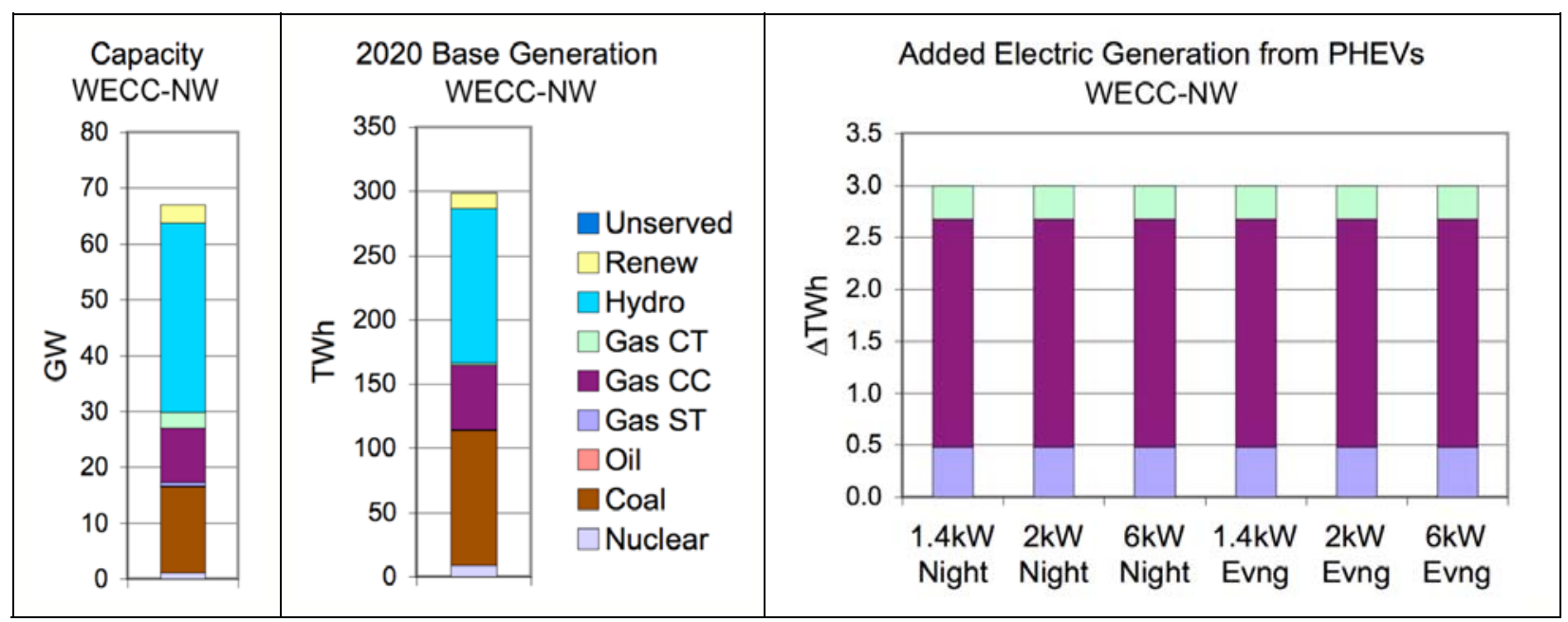

Figure 34. Projected 2020 generating capacity (left), base generation (center), and new generation dispatched to meet demand for each PHEV recharging scenario (right) for WECC-NWP.

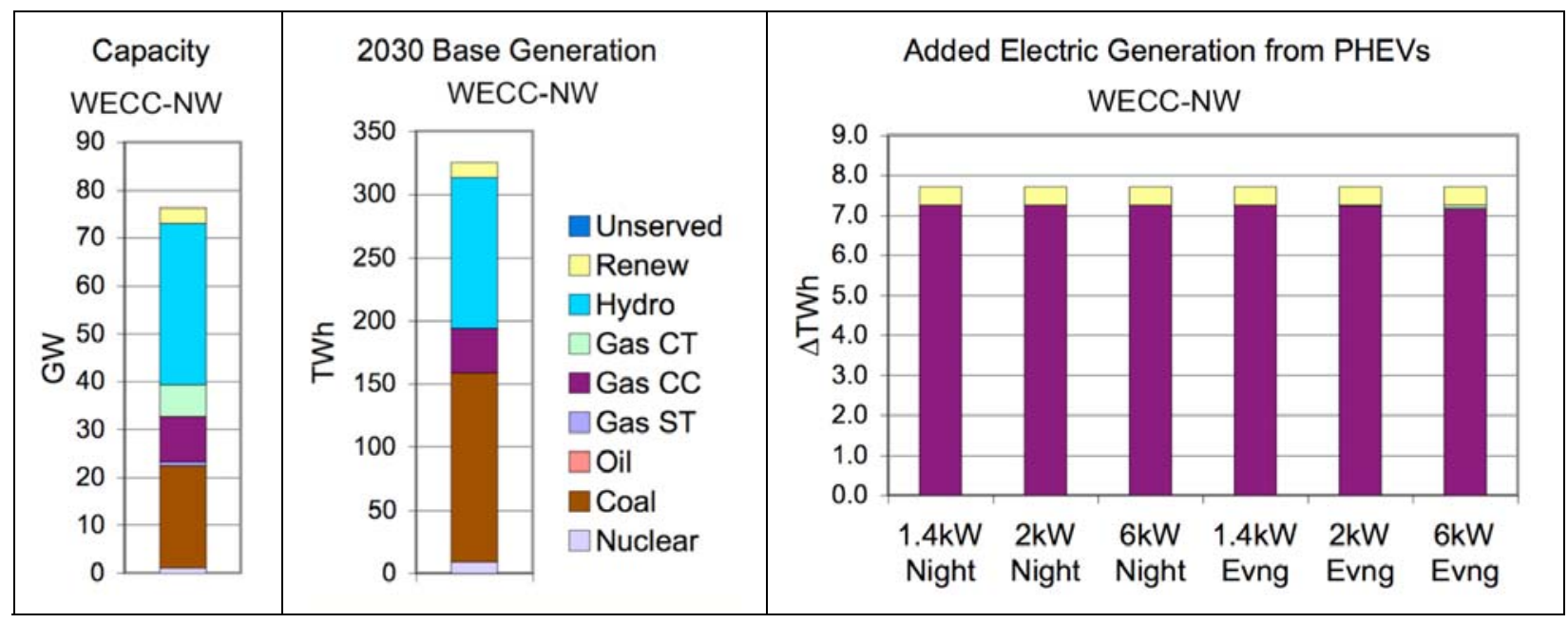

Figure 35. Projected 2030 generating capacity (left), base generation (center), and new generation dispatched to meet demand for each PHEV recharging scenario (right) for WECC-NWP.

Because all scenarios have the same generation mix, the resulting factors are the same in each scenario (Table 42). There actually is a very slight change in the $6 \mathrm{~kW}$ evening scenario for 2030 because a small amount of combustion turbine generation is added to the mix. 
Table 42. Generation, primary energy in, emissions, electricity prices, and PHEV charging costs in 2020 and 2030 for WECC-NW. Numbers in parentheses are percent change from no charging ("None").

\begin{tabular}{|c|c|c|c|c|c|c|c|c|c|c|c|c|c|}
\hline & None & \multicolumn{2}{|c|}{$\begin{array}{c}1.4 \mathrm{~kW} \\
\text { night }\end{array}$} & \multicolumn{2}{|c|}{$\begin{array}{l}2 \mathrm{~kW} \\
\text { night }\end{array}$} & \multicolumn{2}{|c|}{$\begin{array}{l}6 \mathrm{~kW} \\
\text { night }\end{array}$} & \multicolumn{2}{|c|}{$\begin{array}{c}1.4 \mathrm{~kW} \\
\text { evening }\end{array}$} & \multicolumn{2}{|c|}{$\begin{array}{c}2 \mathrm{~kW} \\
\text { evening }\end{array}$} & \multicolumn{2}{|c|}{$\begin{array}{c}6 \mathrm{~kW} \\
\text { evening }\end{array}$} \\
\hline \multicolumn{14}{|l|}{2020} \\
\hline Generation (TWh) & 299 & 302 & $(1.0)$ & 302 & (1.0) & 302 & (1.0) & 302 & $(1.0)$ & 302 & (1.0) & 302 & $(1.0)$ \\
\hline Unserved energy ( $\mathrm{T}$ & 0.0 & 0.0 & & 0.0 & & 0.0 & & 0.0 & & 0.0 & & 0.0 & \\
\hline Energy in (Quads) & 2.93 & 2.96 & $(1.0)$ & 2.96 & $(1.0)$ & 2.96 & (1.0) & 2.96 & $(1.0)$ & 2.96 & $(1.0)$ & 2.96 & (1.0) \\
\hline $\mathrm{CO}_{2}$ (MTon) & 5 & 36 & $(1.2)$ & 136 & $(1.2)$ & 136 & (1.2) & 136 & $(1.2)$ & 136 & (1.2) & 36 & (1.2) \\
\hline $\mathrm{NO}_{\mathrm{x}}$ (kTon) & 193 & 195 & $(1.0)$ & 195 & $(1.0)$ & 195 & $(1.0)$ & 195 & $(1.0)$ & 195 & $(1.0)$ & 195 & $(1.0)$ \\
\hline${ }^{a} \mathrm{SO}_{2}$ (kTon) & 58 & 158 & $(0.0)$ & 158 & $(0.0)$ & 158 & $(0.0)$ & 158 & $(0.0)$ & 158 & $(0.0)$ & 158 & $(0.0)$ \\
\hline Avg wholsle $p$ & 3.73 & 3.78 & (1.3) & 3.78 & (1.3) & 3.78 & (1.3) & 3.78 & (1.3) & 3.78 & (1.3) & 3.78 & (1.3) \\
\hline IEV cost & 0 & 5.54 & & 5.54 & & 5.54 & & 5.54 & & 5.54 & & 5.54 & \\
\hline \multicolumn{14}{|l|}{2030} \\
\hline Generation (TWh) & 326 & 334 & (2.4) & 334 & (2.4) & 334 & (2.4) & 334 & (2.4) & 334 & (2.4) & 334 & (2.4) \\
\hline Unserved e & & 0 & & 0.0 & & 0.0 & & 0.0 & & 0.0 & & 0.0 & \\
\hline Energy in (Quads) & 3.16 & 3.22 & (2.0) & 3.22 & (2.0) & 3.22 & (2.0) & 3.22 & (2.0) & 3.22 & (2.0) & 3.22 & (2.0) \\
\hline $\mathrm{CO}_{2}$ (MTon) & 167 & 170 & (1.9) & 170 & (1.9) & 170 & (1.9) & 170 & (1.9) & 170 & (1.9) & 170 & (1.9) \\
\hline $\mathrm{NO}_{\mathrm{x}}$ (kTon) & 207 & 209 & $(0.9)$ & 209 & $(0.9)$ & 209 & $(0.9)$ & 209 & (0.9) & 209 & $(0.9)$ & 209 & (0.9) \\
\hline${ }^{a} \mathrm{SO}_{2}$ (kTon) & 163 & 167 & (2.1) & 167 & (2.1) & 167 & (2.1) & 167 & (2.1) & 167 & (2.2) & 167 & (2.1) \\
\hline Avg wholsle price ( $(\mathrm{kWh})$ & 2.98 & 3.31 & $(11.1)$ & 3.31 & $(11.1)$ & 3.31 & $(11.1)$ & 3.31 & 11.2) & 3.31 & 11.1) & 3.32 & $(11.6)$ \\
\hline Marg PHEV cost ( $(\mathrm{k} / \mathrm{kWh})$ & 0 & 4.31 & & 4.31 & & 4.31 & & 4.31 & & 4.31 & & 4.36 & \\
\hline
\end{tabular}

${ }^{a} \mathrm{SO}_{2}$ emissions will be offset by reductions due to regulated caps.

The comparison between the fuel use, emissions, and costs for the PHEVs in the region using gasoline versus electricity for the 20 miles per day is shown in Table 43. Because gas is the only fuel used for the PHEV generation in WECC-NWP in 2020 (Figure 34), along with some renewable energy in 2030 (Figure 35), $\mathrm{CO}_{2}$ emissions are lower with PHEVs than with efficient HEVs. $\mathrm{NO}_{\mathrm{X}}$ and $\mathrm{SO}_{2}$ emissions are higher, but the $\mathrm{SO}_{2}$ will be offset by reductions elsewhere in the electric system because of the legal caps on total emissions. Costs are much lower with the PHEVs, less than a third of the gasoline cost. Even if customer prices are triple from what is shown in Table 42 the customer would save money, and so likely would save money charging even at peak times.

Table 43. Comparison of fuels, emissions, and costs for PHEVs using 2-kW recharging versus gasoline-fueled HEVs in WECC-NWP, 2020 and 2030

\begin{tabular}{|c|c|c|c|c|c|c|}
\hline & \multicolumn{3}{|c|}{2020} & \multicolumn{3}{|c|}{2030} \\
\hline & \multirow[t]{2}{*}{$\begin{array}{c}\text { Gasoline- } \\
\text { fueled HEVs }\end{array}$} & \multicolumn{2}{|c|}{$\begin{array}{l}\text { PHEVs charged } \\
\text { from grid }\end{array}$} & \multirow[t]{2}{*}{$\begin{array}{c}\text { Gasoline- } \\
\text { fueled HEVs }\end{array}$} & \multicolumn{2}{|c|}{$\begin{array}{l}\text { PHEVs charged } \\
\text { from grid }\end{array}$} \\
\hline & & 2 kW night & $2 \mathrm{~kW}$ evening & & $2 \mathrm{~kW}$ night & $2 \mathrm{~kW}$ evening \\
\hline Vehicles (million) & 1.04 & & & 2.67 & & \\
\hline \multicolumn{7}{|l|}{ Fuel } \\
\hline - Oil (million barrel) & 4.5 & 0.0 & 0.0 & 11.6 & 0.0 & 0.0 \\
\hline - Coal (million ton) & & 0.00 & 0.00 & & 0.00 & 0.00 \\
\hline - Nat Gas (billion cuft) & & 28 & 28 & & 52 & 52 \\
\hline $\mathrm{CO}_{2}$ (million ton) & 1.8 & 1.7 & 1.7 & 4.7 & 3.1 & 3.1 \\
\hline
\end{tabular}




\begin{tabular}{|c|c|c|c|c|c|c|}
\hline & \multicolumn{3}{|c|}{2020} & \multicolumn{3}{|c|}{2030} \\
\hline & \multirow[t]{2}{*}{$\begin{array}{c}\text { Gasoline- } \\
\text { fueled HEVs }\end{array}$} & \multicolumn{2}{|c|}{$\begin{array}{l}\text { PHEVs charged } \\
\text { from grid }\end{array}$} & \multirow[t]{2}{*}{$\begin{array}{c}\text { Gasoline- } \\
\text { fueled HEVs }\end{array}$} & \multicolumn{2}{|c|}{$\begin{array}{l}\text { PHEVs charged } \\
\text { from grid }\end{array}$} \\
\hline & & $2 \mathrm{~kW}$ night & $2 \mathrm{~kW}$ evening & & $2 \mathrm{~kW}$ night & $2 \mathrm{~kW}$ evening \\
\hline $\mathrm{NO}_{\mathrm{x}}$ (thousand ton) & 0.4 & 1.9 & 1.9 & 1.1 & 1.9 & 1.9 \\
\hline${ }^{a} \mathrm{SO}_{2}$ (thousand ton) & 0 & 0 & 0 & & 3 & 4 \\
\hline${ }^{b}$ Cost (\$million) & 569 & 166 & 166 & 1,464 & 332 & 332 \\
\hline
\end{tabular}

${ }^{a} \mathrm{SO}_{2}$ emissions will be offset by reductions due to regulated caps.

${ }^{b}$ This comparison does not include the added vehicle cost for PHEV batteries or recharging capability, nor the full retail price of electricity.

\subsection{Western Electricity Coordinating Council - Rocky Mountain Power Area and Arizona-New Mexico-Southern Nevada Power Area (WECC - RMP/ANM)}

For the WECC-RMP/ANM region the model predicts sufficient generation capacity to satisfy the demand throughout each year (Table 44). The 2020 scenarios have little impact on the peaks for each season; only the $6 \mathrm{~kW}$ evening charging scenario raises the annual peak, and only from 55.6 to $56.9 \mathrm{GW}$. The 2030 scenarios have slightly more impact, but still only raise the peak demand from 66.6 to $70.9 \mathrm{GW}$, well below the capacity of $80.8 \mathrm{GW}$.

Table 44. Capacity and peak demand in each season under each scenario for 2020 and 2030 in WECC-RMP/ANM (GW)

\begin{tabular}{cccccc|ccc}
\hline & Capacity & $\begin{array}{c}\text { No } \\
\text { charging }\end{array}$ & $\begin{array}{c}\mathbf{1 . 4} \mathbf{~ k W} \\
\text { night }\end{array}$ & $\begin{array}{c}\mathbf{2} \mathbf{k W} \\
\text { night }\end{array}$ & $\begin{array}{c}\mathbf{6} \mathbf{~ k W} \\
\text { night }\end{array}$ & $\begin{array}{c}\mathbf{1 . 4} \mathbf{~ k W} \\
\text { evening }\end{array}$ & $\begin{array}{c}\mathbf{2} \mathbf{~ k W} \\
\text { evening }\end{array}$ & $\begin{array}{c}\mathbf{6} \mathbf{k W} \\
\text { evening }\end{array}$ \\
\hline $\begin{array}{c}\mathbf{2 0 2 0} \\
\text { Summer }\end{array}$ & 66.8 & 55.6 & 55.6 & 55.6 & 55.6 & 55.6 & 55.6 & 56.9 \\
Winter & 68.6 & 36.9 & 36.9 & 36.9 & 36.9 & 37.9 & 38.3 & 39.6 \\
Off-peak & 68.6 & 45.6 & 45.6 & 45.6 & 45.6 & 45.6 & 45.6 & 46.9 \\
\hline $\mathbf{2 0 3 0}$ & & & & & & & & \\
Summer & 80.8 & 66.6 & 66.6 & 66.6 & 66.6 & 66.8 & 67.4 & 70.9 \\
$\quad$ Winter & 82.6 & 44.1 & 44.1 & 44.1 & 45.9 & 46.6 & 47.6 & 51.1 \\
Off-peak & 82.6 & 54.8 & 54.8 & 54.8 & 54.8 & 55.0 & 55.5 & 59.1 \\
\hline
\end{tabular}

The model predicts for 2020 that the overall WECC - RMP/ANM generation mix will be based largely on coal production, but the added production for PHEVs will come almost entirely from gas-fired combined cycle capacity (Figure 36). By 2030 there is expected to be more coal capacity in the region and so coal is on the margin for much of the PHEV supply, especially the night charging scenarios (Figure 37). 


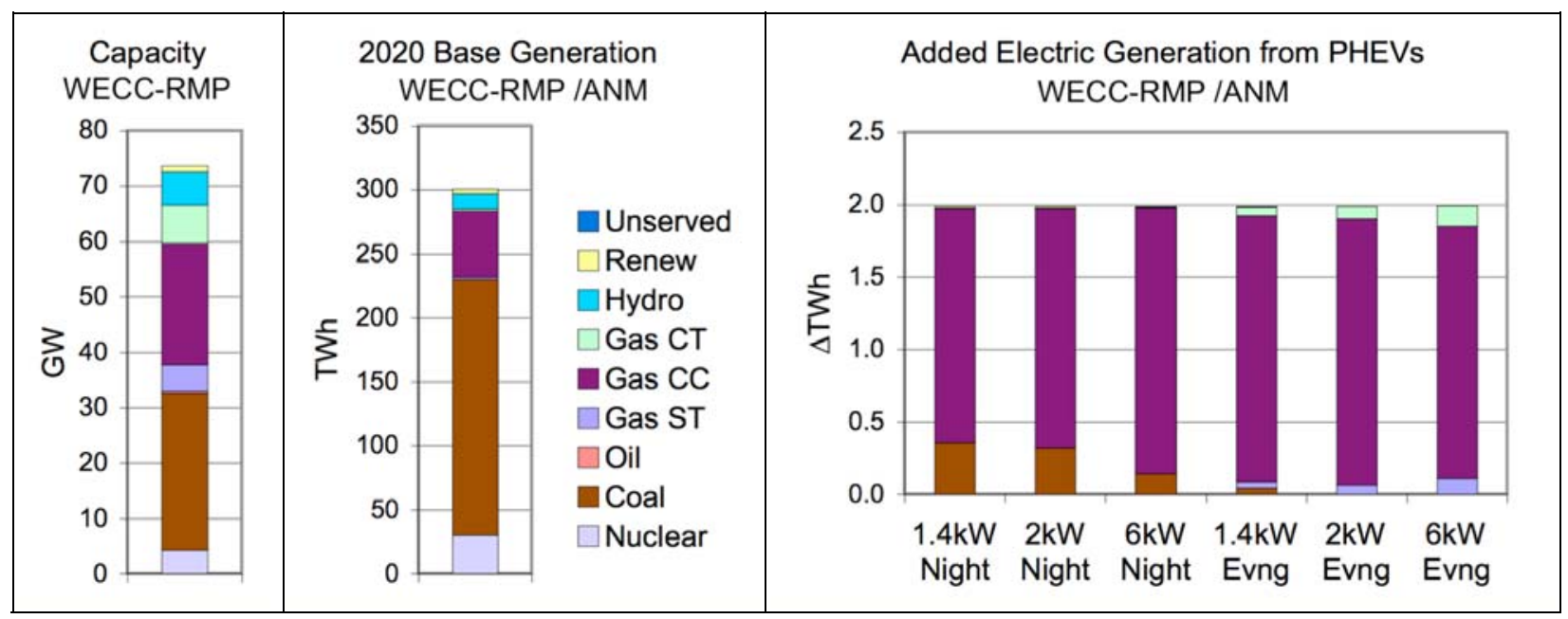

Figure 36. Projected 2020 generating capacity (left), base generation (center), and new generation dispatched to meet demand for each PHEV recharging scenario (right) for WECC-RMP.

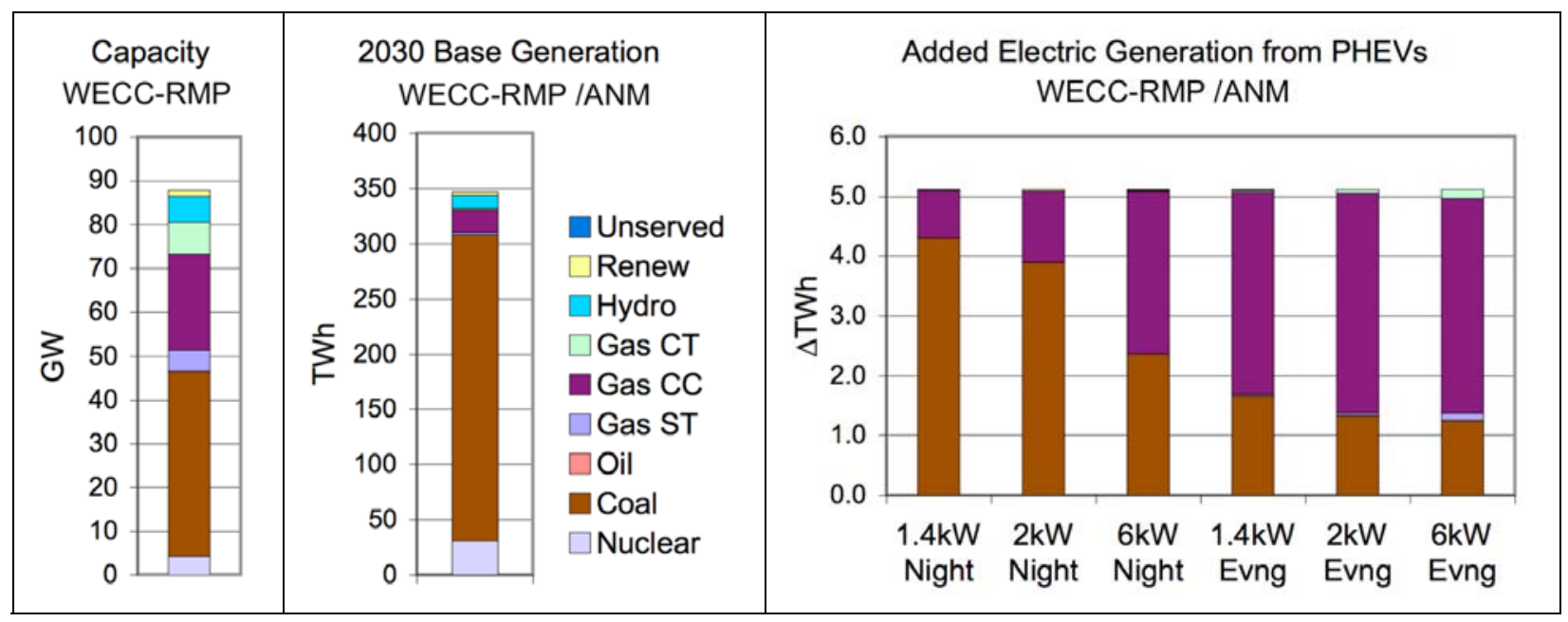

Figure 37. Projected 2020 generating capacity (left), base generation (center), and new generation dispatched to meet demand for each PHEV recharging scenario (right) for WECC-RMP.

The electricity demand of PHEVs is not expected to be large in comparison to overall demand: $0.7 \%$ in 2020 and $1.5 \%$ by 2030 (Table 45). The 2020 values are relatively constant over the span of scenarios, since combined cycle generation is the major provider in each one. The 2030 energy and emissions values decline as PHEV demand moves toward the evening peak and combined cycle production is used instead of coal power. On the other hand, generating costs are lowest for the night scenarios, and all of the 2030 scenarios are low in cost compared to other regions. 
Table 45. Generation, primary energy in, emissions, electricity prices, and PHEV charging costs in 2020 and 2030 for WECC-RMP/ANM. Numbers in parentheses are percent change from no charging ("None").

\begin{tabular}{|c|c|c|c|c|c|c|c|c|c|c|c|c|c|}
\hline & None & \multicolumn{2}{|c|}{$\begin{array}{c}1.4 \mathrm{~kW} \\
\text { night }\end{array}$} & \multicolumn{2}{|c|}{$\begin{array}{l}2 \mathrm{~kW} \\
\text { night }\end{array}$} & \multicolumn{2}{|c|}{$\begin{array}{l}6 \mathrm{~kW} \\
\text { night }\end{array}$} & \multicolumn{2}{|c|}{$\begin{array}{c}1.4 \mathrm{~kW} \\
\text { evening }\end{array}$} & \multicolumn{2}{|c|}{$\begin{array}{c}2 \mathrm{~kW} \\
\text { evening }\end{array}$} & \multicolumn{2}{|c|}{$\begin{array}{c}6 \mathrm{~kW} \\
\text { evening }\end{array}$} \\
\hline \multicolumn{14}{|l|}{2020} \\
\hline Generation (TWh) & 301 & 303 & $(0.7)$ & 303 & $(0.7)$ & 303 & $(0.7)$ & 303 & $(0.7)$ & 303 & $(0.7)$ & 303 & $(0.7)$ \\
\hline Unserved energy (T & 0.0 & 0.0 & & 0.0 & & 0.0 & & 0.0 & & 0.0 & & 0.0 & \\
\hline Energy in (Quads) & 2.89 & 2.90 & $(0.6)$ & 2.90 & $(0.6)$ & 2.90 & $(0.5)$ & 2.90 & $(0.5)$ & 2.90 & $(0.5)$ & 2.90 & $(0.5)$ \\
\hline $\mathrm{CO}_{2}$ (MTon) & 232 & 233 & $(0.5)$ & 233 & $(0.5)$ & 233 & $(0.4)$ & 233 & $(0.4)$ & 233 & $(0.4)$ & 233 & $(0.4)$ \\
\hline $\mathrm{NO}_{\mathrm{x}}$ (kTon) & 280 & 281 & $(0.4)$ & 281 & $(0.4)$ & 281 & $(0.2)$ & 281 & $(0.2)$ & 281 & $(0.2)$ & 281 & $(0.2)$ \\
\hline${ }^{a} \mathrm{SO}_{2}$ (kTon) & 250 & 252 & $(0.5)$ & 252 & $(0.5)$ & 251 & $(0.2)$ & 251 & $(0.1)$ & 250 & $(0.0)$ & 250 & $(0.0)$ \\
\hline Avg wholsle pric & 4.16 & 4.21 & (1.1) & 4.21 & $(1.1)$ & 4.20 & $(0.9)$ & 4.23 & $(1.6)$ & 4.23 & (1.6) & 4.25 & $(2.0)$ \\
\hline Marg PHEV cost & 0 & 3.77 & & 3.73 & & 3.85 & & 4.20 & & 4.31 & & 4.48 & \\
\hline \multicolumn{14}{|l|}{2030} \\
\hline on (TWh) & $34 \pi$ & 352 & (1.5) & 352 & (1.5) & 352 & (1.5) & 352 & (1.5) & 352 & (1.5) & 352 & $(1.5)$ \\
\hline Unserved e & & 0.0 & & 0.0 & & 0.0 & & 0.0 & & 0.0 & & 0.0 & \\
\hline Energy in (Quads) & 3.27 & 3.32 & (1.6) & 3.32 & (1.6) & 3.31 & (1.4) & 3.31 & (1.3) & 3.31 & (1.3) & 3.31 & (1.3) \\
\hline $\mathrm{CO}_{2}$ (MTon) & 282 & 288 & $(1.8)$ & 287 & $(1.7)$ & 286 & (1.4) & 286 & (1.2) & 286 & (1.1) & 286 & $(1.1)$ \\
\hline $\mathrm{NO}_{\mathrm{x}}$ (kTon) & 278 & 285 & $(2.7)$ & 285 & (2.6) & 283 & (1.7) & 282 & (1.3) & 281 & (1.1) & 281 & $(1.0)$ \\
\hline${ }^{a} \mathrm{SO}_{2}$ (kTon) & 205 & 214 & $(4.6)$ & 214 & $(4.4)$ & 210 & (2.6) & 208 & (1.5) & 207 & (1.1) & 207 & $(1.2)$ \\
\hline Avg wholsle price (\$/kWh) & 3.11 & 3.17 & (2.0) & 3.20 & $(2.8)$ & 3.20 & (2.6) & 3.16 & $(1.6)$ & 3.15 & $(1.1)$ & 3.18 & $(2.0)$ \\
\hline Marg PHEV cost $(\$ / k W h)$ & 0 & 2.14 & & 2.35 & & 3.00 & & 3.35 & & 3.52 & & 3.74 & \\
\hline
\end{tabular}

${ }^{a} \mathrm{SO}_{2}$ emissions will be offset by reductions due to regulated caps.

The comparison between fuel use, emissions, and costs for the PHEV vehicles in the region using gasoline versus electricity for the 20 miles per day is shown in Table 46. In the scenarios where gas is the main fuel used for the PHEV demand [both 2020 scenarios (Figure 36) and the evening 2030 scenario (Figure 37)], $\mathrm{CO}_{2}$ emissions are lower with PHEVs than with efficient $\mathrm{HEVs}$. In the 2030 night scenario, though, coal is used extensively and $\mathrm{CO}_{2}$ emissions are higher. $\mathrm{NO}_{\mathrm{x}}$ emissions are higher, and in most scenarios $\mathrm{SO}_{2}$ emissions are too, but the $\mathrm{SO}_{2}$ will be offset by reductions elsewhere in the electric system because of the legal caps on total emissions. Costs are much lower with the PHEVs, less than a fourth of the gasoline cost. Even if customer prices are quadruple what is shown in Table 42 the customer would save money, and so likely would save money charging even at peak times.

Table 46. Comparison of fuels, emissions, and costs for PHEVs using 2-kW recharging versus gasoline-fueled HEVs in WECC-RMP/ANM, 2020 and 2030

\begin{tabular}{|c|c|c|c|c|c|c|}
\hline & \multicolumn{3}{|c|}{2020} & \multicolumn{3}{|c|}{2030} \\
\hline & \multirow[t]{2}{*}{$\begin{array}{c}\text { Gasoline- } \\
\text { fueled HEVs }\end{array}$} & \multicolumn{2}{|c|}{$\begin{array}{l}\text { PHEVs charged } \\
\text { from grid }\end{array}$} & \multirow[t]{2}{*}{$\begin{array}{c}\text { Gasoline- } \\
\text { fueled HEVs }\end{array}$} & \multicolumn{2}{|c|}{$\begin{array}{l}\text { PHEVs charged } \\
\text { from grid }\end{array}$} \\
\hline & & 2 kW night & $2 \mathrm{~kW}$ evening & & $2 \mathrm{~kW}$ night & $2 \mathrm{~kW}$ evening \\
\hline Vehicles (million) & 0.69 & & & 1.78 & & \\
\hline \multicolumn{7}{|l|}{ Fuel } \\
\hline - Oil (million barrel) & 3.0 & 0.0 & 0.0 & 7.7 & 0.0 & 0.0 \\
\hline - Coal (million ton) & & 0.18 & 0.00 & & 2.06 & 0.70 \\
\hline
\end{tabular}




\begin{tabular}{|c|c|c|c|c|c|c|}
\hline & \multicolumn{3}{|c|}{2020} & \multicolumn{3}{|c|}{2030} \\
\hline & \multirow[t]{2}{*}{$\begin{array}{l}\text { Gasoline- } \\
\text { fueled HEVs }\end{array}$} & \multicolumn{2}{|c|}{$\begin{array}{l}\text { PHEVs charged } \\
\text { from grid }\end{array}$} & \multirow[t]{2}{*}{$\begin{array}{c}\text { Gasoline- } \\
\text { fueled HEVs }\end{array}$} & \multicolumn{2}{|c|}{$\begin{array}{l}\text { PHEVs charged } \\
\text { from grid }\end{array}$} \\
\hline & & 2 kW night & $2 \mathrm{~kW}$ evening & & $2 \mathrm{~kW}$ night & $2 \mathrm{~kW}$ evening \\
\hline - Nat Gas (billion cuft) & & 12 & 15 & & 8 & 27 \\
\hline $\mathrm{CO}_{2}$ (million ton) & 1.2 & 1.1 & 0.9 & 3.1 & 4.9 & 3.1 \\
\hline $\mathrm{NO}_{\mathrm{x}}$ (thousand ton) & 0.3 & 1.0 & 0.6 & 0.7 & 7.1 & 2.9 \\
\hline${ }^{a} \mathrm{SO}_{2}$ (thousand ton) & 0 & 1 & 0 & & 9 & 2 \\
\hline${ }^{b}$ Cost (\$million) & 378 & 74 & 86 & 972 & 120 & 180 \\
\hline
\end{tabular}

${ }^{a} \mathrm{SO}_{2}$ emissions will be offset by reductions due to regulated caps.

${ }^{b}$ This comparison does not include the added vehicle cost for PHEV batteries or recharging capability, nor the full retail price of electricity.

\subsection{Western Electricity Coordinating Council - California (WECC - CA)}

The generating capacity of the WECC - CA region is expected to be as high as $85.5 \mathrm{GW}$ by 2030 (Table 47). However, that may be insufficient to cover summer demand in the $6 \mathrm{~kW}$ evening scenario, which is expected to soar to almost $95 \mathrm{GW}$ due to the PHEVs. The model predicts 6.6 million hybrid vehicles in the area by that time, and the reality may be higher with increased emphasis on environmentally friendly lifestyles. The other scenarios in 2030 and the 2020 scenarios appear to have fewer problems with lack of capacity.

Table 47. Capacity and peak demand in each season under each scenario for 2020 and 2030 in WECC-CA (GW)

\begin{tabular}{|c|c|c|c|c|c|c|c|c|}
\hline & Capacity & $\begin{array}{c}\text { No } \\
\text { charging }\end{array}$ & $\begin{array}{c}1.4 \mathrm{~kW} \\
\text { night }\end{array}$ & $\begin{array}{l}2 \mathrm{~kW} \\
\text { night }\end{array}$ & $\begin{array}{l}6 \mathrm{~kW} \\
\text { night }\end{array}$ & $\begin{array}{c}1.4 \mathrm{~kW} \\
\text { evening }\end{array}$ & $\begin{array}{c}2 \mathrm{~kW} \\
\text { evening }\end{array}$ & $\begin{array}{c}6 \mathrm{~kW} \\
\text { evening }\end{array}$ \\
\hline \multicolumn{9}{|l|}{2020} \\
\hline Summer & 72.7 & 62.4 & 62.4 & 62.4 & 62.4 & 62.4 & 62.8 & 68.0 \\
\hline Winter & 72.6 & 44.6 & 44.6 & 44.6 & 44.6 & 48.2 & 49.7 & 54.8 \\
\hline Off-peak & 72.6 & 49.5 & 49.5 & 49.5 & 49.5 & 49.9 & 50.6 & 55.8 \\
\hline \multicolumn{9}{|l|}{2030} \\
\hline Summer & 85.5 & 74.1 & 74.1 & 74.1 & 74.1 & 77.9 & 81.9 & 94.8 \\
\hline Winter & 85.5 & 53.3 & 53.3 & 53.3 & 62.7 & 62.6 & 66.5 & 79.4 \\
\hline Off-peak & 85.5 & 58.9 & 58.9 & 58.9 & 64.3 & 63.8 & 67.7 & 80.6 \\
\hline
\end{tabular}

According to Annual Energy Outlook 2007, the WECC - CA region will derive its electricity from a wide portfolio of technologies, but with coal providing a major component (Figure 38 and Figure 39). Various gas technologies, nuclear, hydro, and renewable generation also provide significant shares. However, Annual Energy Outlook 2007 projects increased coal capacity in the state, but recent legislation since its publication has limited the amount of high greenhouse gas emitting technologies. The marginal production to meet PHEV demands is almost entirely from gas-fired generation, either steam turbines, gas turbines, or combined cycle plants. In 2030, coal is a marginal supplier during night charging, while there is significant unserved energy in the 6 $\mathrm{kW}$ evening scenario. 


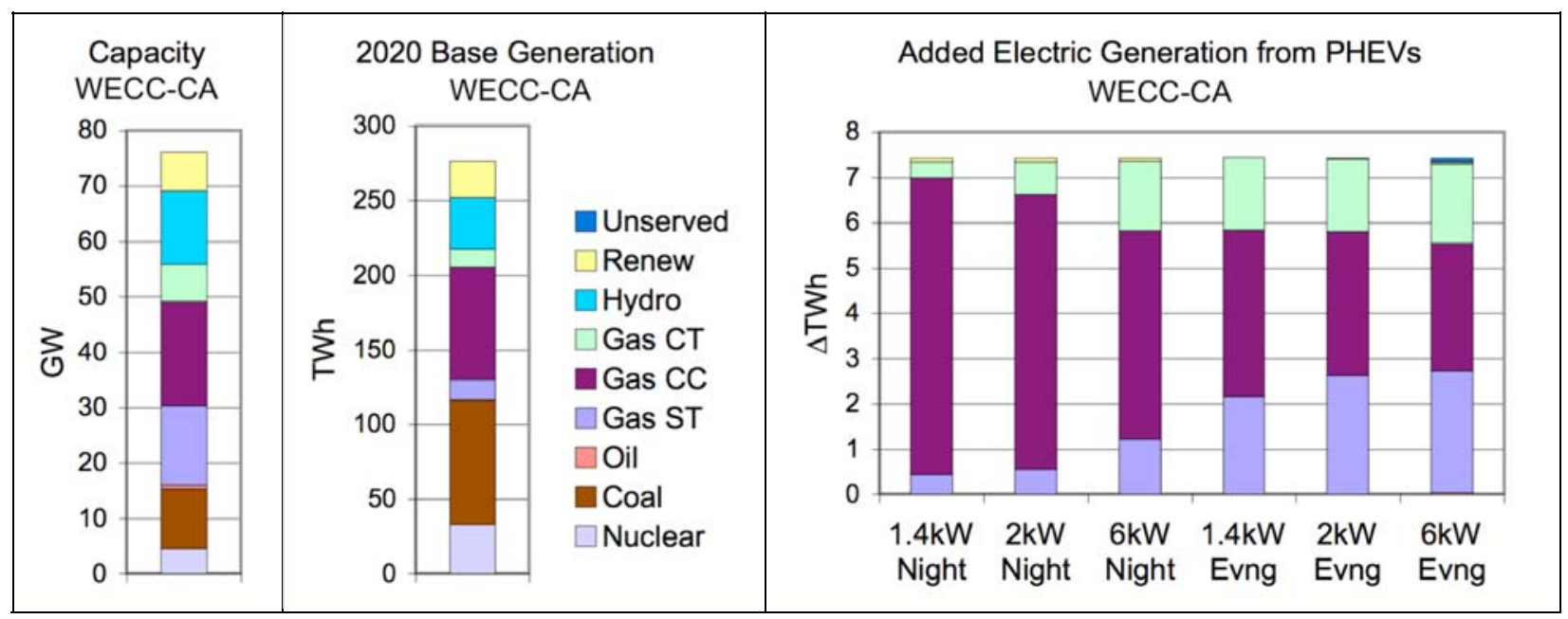

Figure 38. Projected 2020 generating capacity (left), base generation (center), and new generation dispatched to meet demand for each PHEV recharging scenario (right) for WECC-CA.

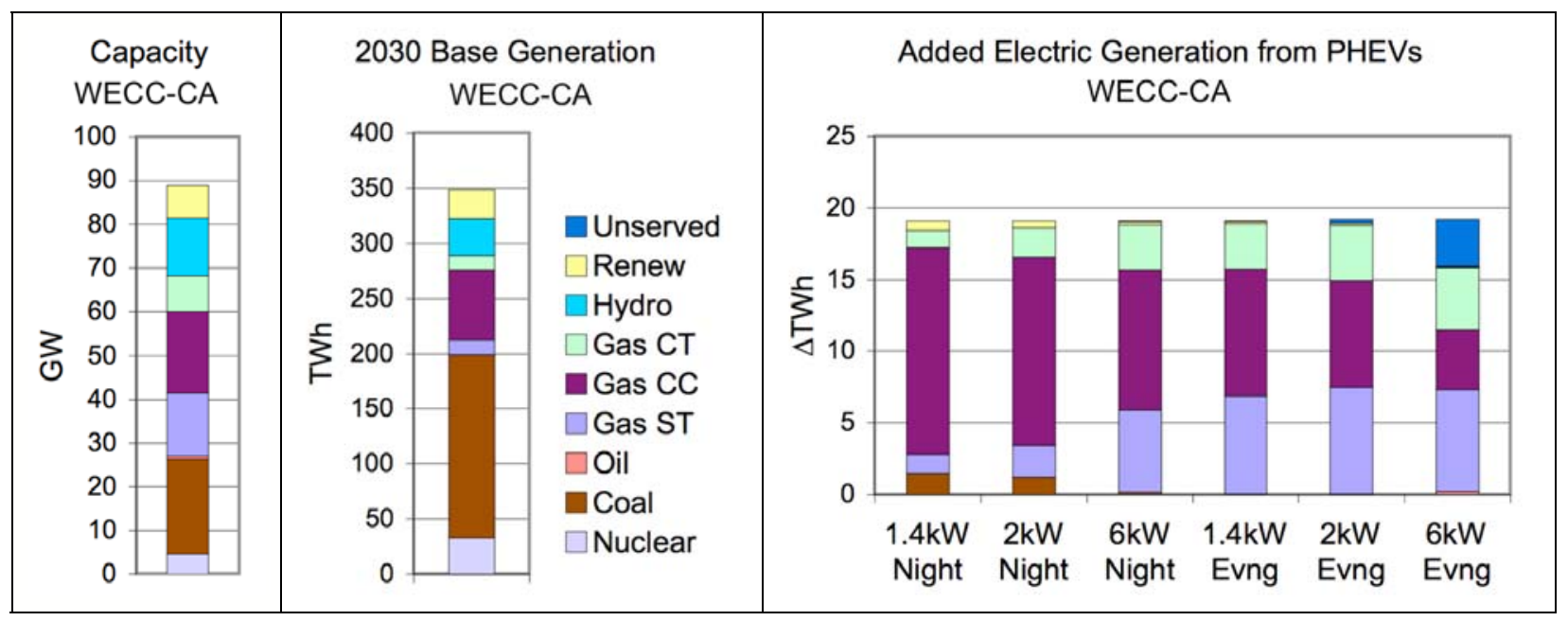

Figure 39. Projected 2030 generating capacity (left), base generation (center), and new generation dispatched to meet demand for each PHEV recharging scenario (right) for WECC-CA.

PHEVs are projected to increase demand by $2.7 \%$ in 2020 and $5.5 \%$ by 2030 (Table 48). For 2020 , where most added power is provided by gas-fired generation, the energy and emissions factors do not vary much. In 2030, the emissions factors tend to decrease with a shift of demand to the evening, as more gas-fired generation and less coal is used. The unserved energy in the last scenario serves to drive up the average price and the PHEV cost significantly. 
Table 48. Generation, primary energy in, emissions, electricity prices, and PHEV charging costs in 2020 and 2030 for WECC-CA. Numbers in parentheses are percent change from no charging ("None").

\begin{tabular}{|c|c|c|c|c|c|c|c|c|c|c|c|c|c|}
\hline & None & \multicolumn{2}{|c|}{$\begin{array}{c}1.4 \mathrm{~kW} \\
\text { night }\end{array}$} & \multicolumn{2}{|c|}{$\begin{array}{l}2 \mathrm{~kW} \\
\text { night }\end{array}$} & \multicolumn{2}{|c|}{$\begin{array}{l}6 \mathrm{~kW} \\
\text { night }\end{array}$} & \multicolumn{2}{|c|}{$\begin{array}{c}1.4 \mathrm{~kW} \\
\text { evening }\end{array}$} & \multicolumn{2}{|c|}{$\begin{array}{c}2 \mathrm{~kW} \\
\text { evening }\end{array}$} & \multicolumn{2}{|c|}{$\begin{array}{c}6 \mathrm{~kW} \\
\text { evening }\end{array}$} \\
\hline Generation (TWh) & 277 & 284 & $(2.7)$ & 284 & $(2.7)$ & 284 & (2.7) & 284 & (2.7) & 284 & $(2.7)$ & 284 & (2.6) \\
\hline Unserved energy ( $\mathrm{T}$ & 0.0 & 0.0 & & 0.0 & & 0.0 & & 0.0 & & 0.0 & & 0.1 & \\
\hline Energy in (C & 2.66 & 2.72 & $(2.1)$ & 2.72 & $(2.2)$ & 2.72 & (2.4) & 2.73 & (2.5) & 2.73 & (2.5) & 2.73 & (2.6) \\
\hline $\mathrm{CO}_{2}$ (MTon) & 126 & 130 & (2.6) & 130 & (2.6) & 130 & (2.9) & 130 & (3.0) & 130 & (3.1) & 130 & (3.2) \\
\hline $\mathrm{NO}_{\mathrm{x}}$ (kTon) & 84 & 85 & $(1.5)$ & 85 & (1.5) & 85 & (1.7) & 85 & (1.6) & 85 & (1.6) & 85 & $(1.8)$ \\
\hline${ }^{a} \mathrm{SO}_{2}$ (kTon) & 25 & 26 & $(1.6)$ & 26 & (1.5) & 26 & (1.3) & 25 & $(0.2)$ & 26 & $(0.5)$ & 26 & (1.3) \\
\hline Avg wholsle price & 5.00 & 5.06 & (1.4) & 5.07 & (1.5) & 5.09 & (1.8) & 5.07 & (1.5) & 5.10 & (2.0) & 5.44 & $(9.0)$ \\
\hline Marg PHEV cost ( $(\mathrm{k} / \mathrm{kWh})$ & 0 & 4.66 & & 4.67 & & 5.11 & & 5.41 & & 5.53 & & 6.65 & \\
\hline \multicolumn{14}{|l|}{2030} \\
\hline Generation (TWh) & 348 & 367 & (5.5) & 367 & (5.5) & 367 & (5.5) & 367 & (5.5) & 367 & (5.4) & 364 & $(4.5)$ \\
\hline Unserved energy (- & 0.0 & 0.0 & & 0.0 & & 0.0 & & 0.0 & & 0.3 & & 3.3 & \\
\hline Energy in (Quads) & 3.29 & 3.44 & $(4.7)$ & 3.45 & (4.8) & 3.46 & (5.2) & 3.46 & $(5.2)$ & 3.47 & $(5.4)$ & 3.45 & $(4.8)$ \\
\hline $\mathrm{CO}_{2}$ (MTon) & 195 & 204 & $(4.7)$ & 205 & $(4.8)$ & 205 & $(5.0)$ & 205 & $(5.1)$ & 205 & $(5.2)$ & 205 & $(4.8)$ \\
\hline $\mathrm{NO}_{\mathrm{x}}$ (kTon) & 119 & 125 & $(4.6)$ & 124 & $(4.2)$ & 123 & (3.2) & 123 & (3.1) & 123 & $(3.0)$ & 122 & $(2.7)$ \\
\hline${ }^{a} \mathrm{SO}_{2}$ (kTon) & 36 & 38 & $(5.8)$ & 38 & (4.9) & 37 & (3.4) & 37 & (2.6) & 37 & $(2.7)$ & 37 & $(1.7)$ \\
\hline Avg wholsle price (屯/kWh) & 4.62 & 5.04 & $(9.1)$ & 5.00 & $(8.2)$ & 5.10 & 10.3) & 5.09 & 10.1) & 5.76 & (24.7) & 13.25 & (187) \\
\hline Marg PHEV cost ( $(\mathrm{k} / \mathrm{kWh})$ & 0 & 4.57 & & 4.68 & & 5.41 & & 5.54 & & 6.56 & & 43.38 & \\
\hline
\end{tabular}

${ }^{\mathrm{a}} \mathrm{SO}_{2}$ emissions will be offset by reductions due to regulated caps.

The comparison between fuel use, emissions, and costs for the PHEV vehicles in the region using gasoline versus electricity for the 20 miles per day is shown in Table 49. In all of the scenarios (Figure 38 and Figure 39), $\mathrm{CO}_{2}$ emissions are lower with PHEVs than with efficient HEVs. $\mathrm{NO}_{\mathrm{X}}$ emissions are about the same in 2020, and in the 2030 evening scenario the emissions are very close. The 2030 night scenario, however, has some coal production and renewable on the margin so has somewhat higher $\mathrm{NO}_{\mathrm{X}}$ emissions. $\mathrm{SO}_{2}$ emissions are much lower comparatively than in other regions but still are positive, but the $\mathrm{SO}_{2}$ will be offset by reductions elsewhere in the electric system because of the legal caps on total emissions. Costs are much lower with the PHEVs, less than a third of the gasoline cost. Even if customer prices are triple from what is shown in Table 48 the customer would save money, and so likely would save money charging even at peak times.

Table 49. Comparison of fuels, emissions, and costs for PHEVs using 2-kW recharging versus gasoline-fueled HEVs in WECC-CA, 2020 and 2030

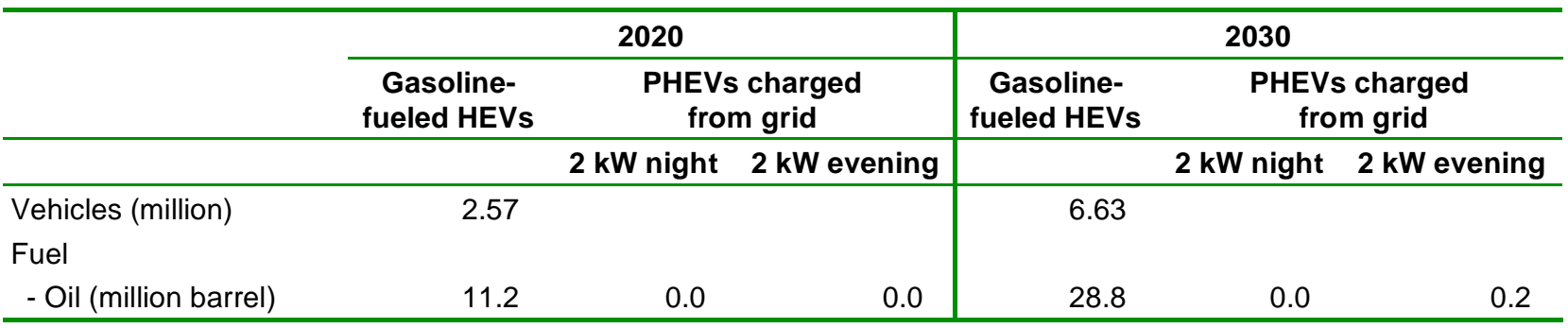




\begin{tabular}{|c|c|c|c|c|c|c|}
\hline & \multicolumn{3}{|c|}{2020} & \multicolumn{3}{|c|}{2030} \\
\hline & \multirow[t]{2}{*}{$\begin{array}{c}\text { Gasoline- } \\
\text { fueled HEVs }\end{array}$} & \multicolumn{2}{|c|}{$\begin{array}{l}\text { PHEVs charged } \\
\text { from grid }\end{array}$} & \multirow[t]{2}{*}{$\begin{array}{c}\text { Gasoline- } \\
\text { fueled HEVs }\end{array}$} & \multicolumn{2}{|c|}{$\begin{array}{l}\text { PHEVs charged } \\
\text { from grid }\end{array}$} \\
\hline & & 2 kW night & $2 \mathrm{~kW}$ evening & & $2 \mathrm{~kW}$ night & $2 \mathrm{~kW}$ evening \\
\hline - Coal (million ton) & & 0.00 & 0.00 & & 0.57 & 0.0 \\
\hline - Nat Gas (billion cuft) & & 56 & 66 & & 135 & 171 \\
\hline $\mathrm{CO}_{2}$ (million ton) & 4.6 & 3.3 & 3.9 & 11.7 & 9.3 & 10.2 \\
\hline $\mathrm{NO}_{\mathrm{x}}$ (thousand ton) & 1.0 & 1.2 & 1.4 & 2.7 & 4.3 & 2.9 \\
\hline${ }^{a} \mathrm{SO}_{2}$ (thousand ton) & 0 & 0.4 & 0.1 & & 1.8 & 1.0 \\
\hline${ }^{b}$ Cost (\$million) & 1,410 & 347 & 410 & 3,627 & 894 & 1,252 \\
\hline
\end{tabular}

${ }^{a} \mathrm{SO}_{2}$ emissions will be offset by reductions due to regulated caps.

${ }^{b}$ This comparison does not include the added vehicle cost for PHEV batteries or recharging capability, nor the full retail price of electricity. 


\section{Summary}

In aggregate, the model predicts an increase in demand, generation, electricity prices, and emissions from the utilities created by the introduction of PHEVs. It also suggests that by 2030 almost all regions (10 out of 13) will need to add capacity to provide for charging PHEVs, mostly in the scenario where PHEVs are charged at $6 \mathrm{~kW}$ in the evenings. In all likelihood, to avoid these problems the utilities in the regions would expand their capacity, increase their imports, or establish demand response programs beyond the level that NEMS had calculated, but these factors were not modeled in the scenarios.

The specific results differ from region to region and are to varying extent sensitive to the alterations of the scenario considered. Some of the indicators are less sensitive to the charging rate, others to time of charging. Predicted changes in the Western Electricity Coordinating Council - Northwest Power Pool Area are all the same regardless of the analysis setting. Overall, increase in generation is least responsive to the set up, while price is the most sensitive. The changes in emissions levels do not follow any constant patterns; in some regions they are higher with night recharging, in some with evening recharging, depending on the predicted generation mix and capacity available to satisfy increased demand.

Electricity price is the most sensitive indicator estimated by the model. Depending on the scenario, price may increase by only $1.2 \%-2.7 \%$ (in WECC - RMP/ANM) or, for evening recharging at $6 \mathrm{~kW}$, by as much as 141\% (in FRCC), 196\% (in WECC-CA) and 297\% (in SERC). In contrast to what was suggested by other research (Kinter-Meyer, Schneider and Pratt, 2007), the model predicts increases in electricity prices for almost all regions. The most likely explanation for this is the competitive electricity market assumption incorporated into the model. Increased demand, which has to be met by the capacity planned without consideration of possible effects of PHEVs, drives prices up. The only region that, under certain circumstances, may experience price drops is FRCC. If the hybrids' owners prefer to recharge their vehicles at night and less powerful batteries are utilized for hybrid production $(1.4 \mathrm{~kW}$ or $2 \mathrm{~kW})$, this will exert downward pressure on prices, which may decrease by $3.2 \%$ and $2.2 \%$ respectively. This result is contingent on time of recharging. If the owners plug in their PHEVs earlier, electricity prices may increase by 41 to $141 \%$.

The generation mix varies substantially from region to region, as well as regions' means of satisfying the increased demand associated with PHEV market penetration. The majority of regions are likely to use their coal and gas technologies. Some of the regions may increase their oil based electricity generation (e.g., MAAC and NPCC - NY), which may diminish the positive effects of PHEVs. Other regions are expected to increase their renewable electricity generation as a response to the increased demand (e.g., WECC - NW). The evening charging scenario is more likely to increase oil-based generation, while later charging is more conductive to adding renewable generation. Coal plays a role mainly in the Midwest and South, and generally during night charging periods, as in the VACAR region described earlier. A few regions show renewables, mainly biomass, as a marginal fuel. New England has the largest amount, with power coming from wood-fired power plants. The NPCC/New York region shows a large component of oil-fired generation, despite oil representing less than $7 \%$ of generation in the 
region. There are a number of plants that can operate with either natural gas or residual fuel oil, and ORCED modeled them as running on oil because of the lower cost of fuel.

Emissions levels are highly sensitive to region, recharging power, and time of recharging. For some regions emissions grow more in the night recharging scenario, for some the opposite is true. All emissions are expected to increase, though for some regions by a very small percentage. For example, the increase in $\mathrm{SO}_{2}$ emissions in the SPP region under the evening recharging scenario is expected to be only $0.6-0.7 \%$. The $\mathrm{NO}_{\mathrm{x}}$ emissions in the WECC $-\mathrm{NW}$ area are predicted to go up by $0.9 \%$ regardless of charging scenario.

Table 50 gives a generalized description of how the fuels used to generate electricity change in each region, contrasting night charging and evening charging, for 2020 and 2030. Where the table identifies "gas" as the fuel, it may be used in combustion turbines, steam turbines, or combined cycle plants. More specific changes for each region are shown in figures in their sections.

Table 50. Generalized description of the types of fuels expected to be used to generate added electricity load for charging PHEVs in each region, 2020 and 2030

\begin{tabular}{rlcccc}
\hline & & \multicolumn{2}{c}{$\mathbf{2 0 2 0}$} & \multicolumn{2}{c}{$\mathbf{2 0 3 0}$} \\
\cline { 3 - 6 } & & $\begin{array}{c}\mathbf{1 0} \text { p.m. } \\
\text { charging }\end{array}$ & $\begin{array}{c}\mathbf{5} \text { p.m. } \\
\text { charging }\end{array}$ & $\begin{array}{c}\mathbf{1 0} \text { p.m. } \\
\text { charging }\end{array}$ & $\begin{array}{c}\mathbf{5} \text { p.m. } \\
\text { charging }\end{array}$ \\
\hline 1 & ECAR & $70 \%$ coal & $50 \%$ coal & $50 \%$ coal & $30 \%$ coal \\
2 & ERCOT & gas & gas & gas & gas + unserved \\
3 & MAAC & gas + coal & gas + oil & gas + coal & gas + oil \\
4 & MAIN & $75 \%$ coal & $50 \%$ coal & $40 \%$ coal & $25 \%$ coal \\
5 & MAPP & $50 \%$ coal & gas & $40 \%$ coal & gas \\
6 & NPCC-NY & oil + gas & oil + gas & gas & gas \\
7 & NPCC-NE & gas + coal & gas + oil & gas & gas + oil + coal \\
8 & FRCC & gas & gas + oil & coal + gas & gas + unserved \\
9 & SERC & $50 \%$ coal & $20 \%$ coal & $60 \%$ coal & $20 \%$ coal \\
10 & SPP & gas & gas & gas + coal & gas \\
11 & WECC-NW & gas & gas & gas & gas \\
12 & WECC-RMP/ANM & gas & gas & $80 \%$ coal & $25 \%$ coal \\
13 & WECC-CA & gas & gas & gas & gas + unserved \\
\hline Note: "Gas” may be used for combustion turbines, steam turbines, or combined cycle plants.
\end{tabular}

The national results for capacity and generation by technology are shown in Figure 40 and Figure 41. According to Annual Energy Outlook 2007, coal generation plays a growing role in U.S. power generation. Added demand from PHEVs across the country is met by a combination of coal and combined cycle production in the night scenarios, with small amounts from other gas technologies, oil, and renewables. As demand moves towards the evening peak, combustion turbines and a surprising amount of oil generation are called on. Peak loads from $6 \mathrm{~kW}$ charging in the evening will require significant additional capacity by 2030 to avoid unserved energy. 


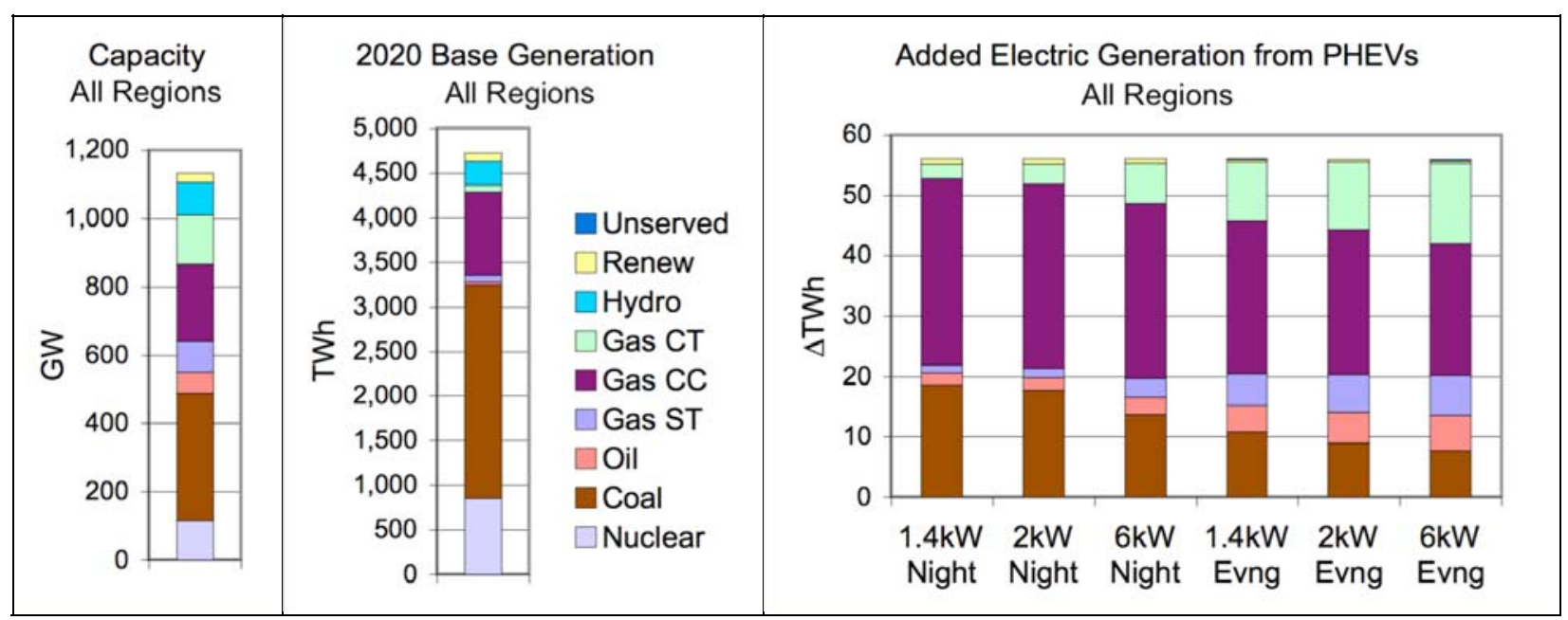

Figure 40. Sum for all regions of projected 2020 generating capacity (left), base generation (center), and new generation dispatched to meet demand for each PHEV recharging scenario (right).

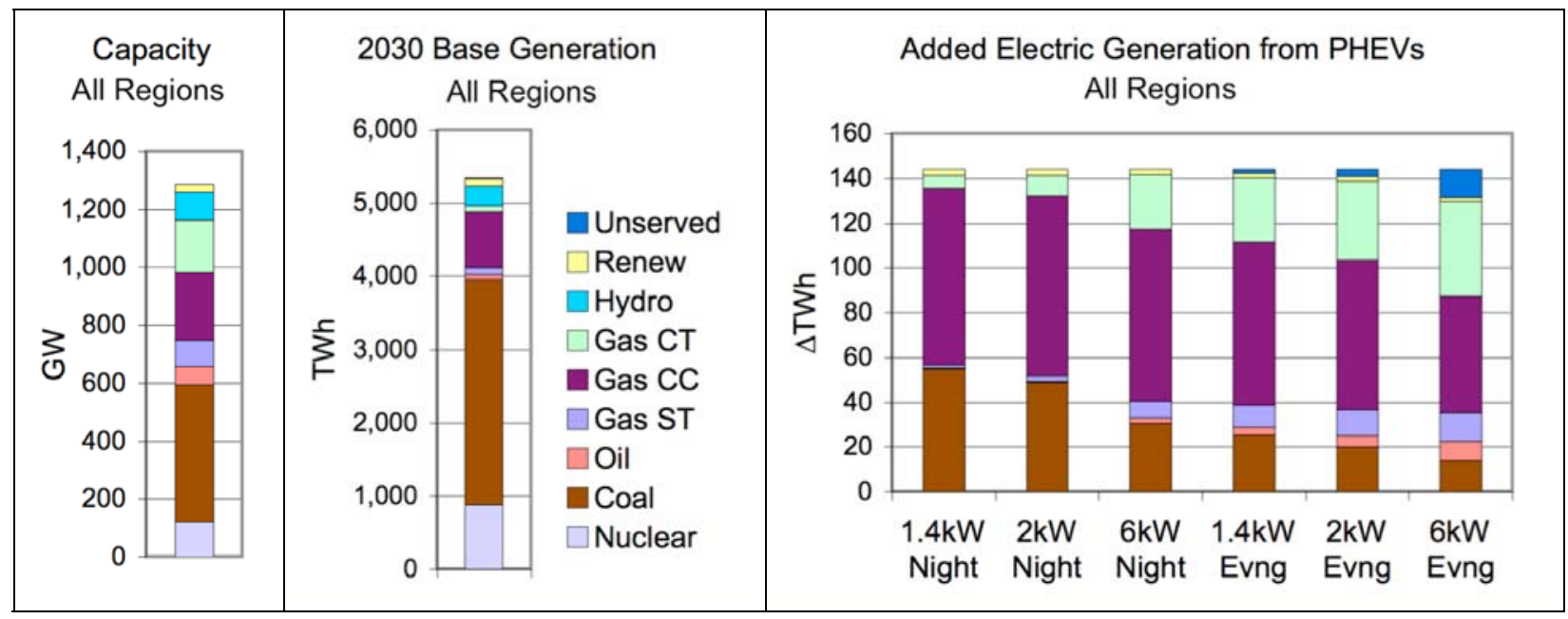

Figure 41. Sum for all regions of projected 2030 generating capacity (left), base generation (center), and new generation dispatched to meet demand for each PHEV recharging scenario (right).

Total generation, emissions, and costs, are shown in Table 51. The predicted impacts in 2020 generally scale to the amount of added generation required, $1.2 \% . \mathrm{NO}_{\mathrm{X}}$ and $\mathrm{SO}_{2}$ emissions (before adjustment of caps) decline as generation shifts to peak periods, while prices and costs increase. Similarly, in 2030 increases in energy use and $\mathrm{CO}_{2}$ production are slightly less than the $2.7 \%$ growth in generation requirements. $\mathrm{NO}_{\mathrm{X}}$ and $\mathrm{SO}_{2}$ emission follow the same trend of declining with the shift to peak power. Because our analysis did not include new capacity to meet the added peak demand, unserved energy plays a significant role in the $6 \mathrm{~kW}$ evening scenario, with a consequent large increase in average cost. 
Table 51. Generation, primary energy in, emissions, and electricity prices and costs in 2020 and 2030 for all regions

\begin{tabular}{|c|c|c|c|c|c|c|c|c|c|c|c|c|c|}
\hline $20<0$ & None & \multicolumn{2}{|c|}{$\begin{array}{c}1.4 \mathrm{~kW} \\
\text { night }\end{array}$} & \multicolumn{2}{|c|}{$\begin{array}{l}2 \mathrm{~kW} \\
\text { night }\end{array}$} & \multicolumn{2}{|c|}{$\begin{array}{l}6 \mathrm{~kW} \\
\text { night }\end{array}$} & \multicolumn{2}{|c|}{$\begin{array}{c}1.4 \mathrm{~kW} \\
\text { evening }\end{array}$} & \multicolumn{2}{|c|}{$\begin{array}{c}2 \text { kW } \\
\text { evening }\end{array}$} & \multicolumn{2}{|c|}{$\begin{array}{c}6 \mathrm{~kW} \\
\text { evening }\end{array}$} \\
\hline Generation (PWh) & .73 & 4.78 & $(1.2)$ & 4.78 & $(1.2)$ & 4.78 & $(1.2)$ & 4.78 & (1.2) & 4.78 & (1.2) & 4.78 & (1.2) \\
\hline Unserved energy ( $\mathrm{T}$ & 0.0 & 0.0 & & 0.0 & & 0.0 & & 0.0 & & 0.0 & & 0.3 & \\
\hline Energy in (Quads) & 45.74 & 46.24 & (1.1) & 46.24 & (1.1) & 46.25 & $(1.1)$ & 46.27 & $(1.2)$ & 46.27 & (1.2) & 46.29 & (1.2) \\
\hline CO2 (GTon) & 06 & 3.10 & $(1.2)$ & 3.10 & $(1.2)$ & 3.10 & $(1.2)$ & 3.10 & $(1.2)$ & .10 & (1.2) & 3.10 & $(1.2)$ \\
\hline${ }^{a} \mathrm{NO}_{\mathrm{x}}$ (MTon) & 3.13 & 3.17 & $(1.4)$ & 3.17 & $(1.4)$ & 3.17 & $(1.4)$ & 3.17 & $(1.4)$ & 3.17 & (1.4) & 3.17 & (1.4) \\
\hline${ }^{a} \mathrm{SO}_{2}$ (MTon) & 10.53 & 10.77 & (2.3) & 10.78 & (2.3) & 10.75 & $(2.1)$ & 10.79 & (2.5) & 10.82 & (2.7) & 11.03 & (4.8) \\
\hline Avg wholsle $p$ & 5.05 & 5.09 & $(0.7)$ & 5.10 & $(0.9)$ & 5.11 & $(1.1)$ & 5.20 & (3.0) & 5.26 & $(4.2)$ & 5.61 & $(11.0)$ \\
\hline EV cost & 0 & 4.38 & & 4.46 & & 4.78 & & 5.50 & & 5.88 & & 7.96 & \\
\hline \multicolumn{14}{|l|}{2030} \\
\hline Generation (PWh) & 5.34 & 5.48 & $(0.0)$ & 5.48 & $(0.0)$ & 5.48 & $(0.0)$ & 5.48 & $(0.0)$ & 5.48 & $(0.0)$ & 5.47 & $0.0)$ \\
\hline Unserved e & 2.7 & 2.7 & & 2.7 & & 2.8 & & 4.5 & & 6.0 & & 15.6 & \\
\hline Energy in (Quads) & 51.17 & 52.43 & (2.5) & 52.42 & $(2.5)$ & 52.44 & (2.5) & 52.45 & (2.5) & 52.47 & (2.5) & 52.46 & (2.5) \\
\hline co2 (GTon) & 3.63 & 3.73 & (3.2) & 3.73 & (3.1) & 3.72 & (2.8) & 3.72 & (2.7) & 3.72 & (2.7) & 3.71 & (2.7) \\
\hline${ }^{a} \mathrm{NO}_{\mathrm{x}}$ (MTon) & 3.35 & 3.45 & (5.3) & 3.45 & $(4.9)$ & 3.44 & (3.8) & 3.44 & (3.5) & 3.44 & (3.1) & 3.44 & (2.4) \\
\hline${ }^{\mathrm{a}} \mathrm{SO}_{2}$ (MTon) & 10.15 & 10.68 & $(2.0)$ & 10.65 & (2.2) & 10.53 & $(4.1)$ & 10.50 & (10.1) & 10.46 & (16.5) & 10.39 & $(53.1)$ \\
\hline Avg wholsle price ( $(\mathrm{kWh})$ & 5.10 & 5.20 & $(2.0)$ & 5.21 & $(2.2)$ & 5.31 & $(4.1)$ & 5.62 & (10.1) & 5.94 & (16.5) & 7.81 & $(53.1)$ \\
\hline Marg PHEV cost ( $(\mathrm{k} / \mathrm{kWh})$ & 0 & 4.17 & & 4.29 & & 4.92 & & 6.96 & & 8.92 & & 25.73 & \\
\hline
\end{tabular}

${ }^{*} \mathrm{NOx}$ and $\mathrm{SO} 2$ emissions will be offset by reductions due to caps.

The comparison of fuel use, emissions, and costs for PHEVs across all regions using gasoline versus electricity for the 20 miles per day is shown in Table 52. In both of the 2020 scenarios (Figure 40) and the night scenario in 2030 (Figure 41), $\mathrm{CO}_{2}$ emissions are higher with PHEVs than with efficient HEVs. Coal and oil generation is sufficient to raise $\mathrm{CO}_{2}$ emissions higher than if the vehicles had used gasoline. However, in the $20302 \mathrm{~kW}$ evening scenario, $\mathrm{CO}_{2}$ emissions are lower, because higher-efficiency combined cycle plants and gas-fired turbines with relatively low emissions are used to meet the added demand. Even though $\mathrm{NO}_{\mathrm{X}}$ emissions at first calculation are much higher for much of the country, these will be offset by reductions elsewhere. Even though new power plants are very clean, the plants that are on the margin and are run because of the extra demand may actually be older plants with higher emissions. $\mathrm{SO}_{2}$ emissions are likewise positive, but will be offset by reductions elsewhere in the electric system because of the legal caps on total emissions. Costs are much lower with the PHEVs, from $22 \%$ to $42 \%$ of the gasoline cost, depending on the scenario. Electricity is likely to be much cheaper than gasoline, though this does not take into account the added initial cost of the plug-in capability for the vehicle. 
Table 52. Comparison of fuels, emissions, and costs predicted for PHEVs using $2 \mathrm{~kW}$ recharging versus gasoline-fueled HEVs, sum of all regions, 2020 and 2030

\begin{tabular}{|c|c|c|c|c|c|c|}
\hline & \multicolumn{3}{|c|}{2020} & \multicolumn{3}{|c|}{2030} \\
\hline & Gasoline & 2 kW Night & $\begin{array}{c}2 \mathrm{~kW} \\
\text { Evening }\end{array}$ & Gasoline & 2 kW Night & $\begin{array}{c}2 \mathrm{~kW} \\
\text { Evening }\end{array}$ \\
\hline Vehicles (million) & 19.45 & & & 50.04 & & \\
\hline \multicolumn{7}{|l|}{ Fuel } \\
\hline - Oil (million barrel) & 84.5 & 4.2 & 10.4 & 217.5 & 0.5 & 11.8 \\
\hline - Coal (MTon) & & 9.26 & 4.84 & & 25.30 & 10.70 \\
\hline - Nat Gas (billion cuft) & & 270 & 367 & & 678 & 970 \\
\hline $\mathrm{CO}_{2}$ (MTon) & 34.4 & 37.8 & 36.9 & 88.5 & 94.5 & 86.1 \\
\hline${ }^{a} \mathrm{NO}_{\mathrm{x}}(\mathrm{kTon})$ & 7.8 & 44.5 & 42.3 & 20.2 & 102.2 & 91.6 \\
\hline${ }^{a} \mathrm{SO}_{2}$ (kTon) & 0 & 246 & 288 & & 500 & 316 \\
\hline${ }^{b}$ Cost (\$million) & 10,647 & 2,500 & 3,294 & 27,399 & 6,186 & 12,858 \\
\hline
\end{tabular}

${ }^{a} \mathrm{NO}_{\mathrm{x}}$ and $\mathrm{SO}_{2}$ emissions will be offset by reductions due to regulated caps.

${ }^{b}$ This comparison does not include the added vehicle cost for PHEV batteries or recharging capability, nor the full retail price of electricity.

This analysis does use simplifications in modeling supply and demand in the electric sector. It applies rigid recharging schedules to all vehicles in each scenario, it does not adjust electricity supply to meet increased demand, its inventory of supply is based on results from a different model (NEMS) that simulates supply and demand somewhat differently, it does not model the transmission system, and it does not reflect all the complexities of air emissions regulations. However, it does offer insights into the issues involved with PHEVs and the electric grid.

This analysis identifies some of the complexities in analyzing the integrated system of PHEVs and the grid. Depending on the power level, timing, and duration of PHEV connections to the grid, there could be a variety of impacts on grid constraints, capacity needs, fuel types used, and emissions generated. Some areas that could be more fully explored include the following.

- The impact of PHEV operation schemes (longer distance batteries, partial charging, frequent short-term charging, vehicle to grid generation)

- Transmission and distribution impacts of PHEVs

- Options for utilities to use to modify customer behavior

- Options for utilities and PHEV manufacturers to use to improve the vehicle/grid system

- Options for utilities to take advantage of PHEV characteristics to improve grid reliability

As shown by this analysis, PHEV penetration of the vehicle market will create substantial changes for the electrical grid. By evaluating these issues early, DOE will be able to help utilities, manufacturers, and regulators understand the issues involved, suggest ideas that will better optimize the combined system, and help avoid negative consequences. 


\section{References}

BTS (Bureau of Transport Statistics) 2005, State Transportation Statistics 2005, U.S.

Department of Transportation Research and Innovative Technology Administration, December.

<http://www.bts.gov/publications/state transportation profiles/state transportation statistics 20 $\underline{\text { 05/index.html }>}$

DOE 2006a, (U.S. Department of Energy), "Clean Cities: Clean Cities Now" Clean Cities Feb. 2006. Clean Cities Now - Vol. 10, No. 1

http://www.eere.energy.gov/cleancities/ccn/archive/ccn $101 . \mathrm{html}$

DOE 2006b, 2006, Summary Report. Discussion Meeting on Plug-In Hybrid Electric Vehicles, Washington, D.C. May 4-5.

<http://www1.eere.energy.gov/vehiclesandfuels/pdfs/program/plug-in summary rpt.pdf $>$

Duvall, Mark S., 2006, Plug-In Hybrid Electric Vehicles Technology Challenges, Presentation at the U.S. DOE Plug-In Hybrid Discussion Meeting, Electric Power Research Institute, May 4-5.

EIA (Energy Information Administration) 2007, Annual Energy Outlook 2007 with Projections to 2030, DOE/EIA-0383(2007), U.S. Department of Energy, Washington, D.C. February.

<http://www.eia.doe.gov/oiaf/aeo/index.html>

EPRI (Electric Power Research Institute) 2002, Comparing the Benefits and Impacts of Hybrid Electric Vehicle Options for Compact Sedans and Sport Utility Vehicles, Palo Alto, CA, 1006892. <http://www.evworld.com/library/EPRI_sedan_options.pdf>

Hadley, S. and E. Hirst 1998, ORCED: A Model to Simulate the Operations and Costs of Bulk Power Markets, ORNL/CON464, Oak Ridge National Laboratory, Oak Ridge, TN, June.

<http://www.ornl.gov/orced/index.html>

Hadley, Stanton W. 2006, Impact of Plug-in Hybrid Vehicles on the Electric Grid, ORNL/TM2006-554, Oak Ridge National Laboratory, October.

<http://www.ornl.org/info/ornlreview/v40_2_07/2007_plug-in_paper.pdf>

Hadley, Stanton W. 2007, Evaluating the Impact of Plug-in Hybrid Electric Vehicles on Regional Electricity Supplies, Paper prepared for the Bulk Power System Dynamics and Control - VII Conference, August 19-24, 2007, Charleston, South Carolina, USA

Hadley, Stanton W. 2008, The Oak Ridge Competitive Electricity Dispatch (ORCED) Model, ORNL/TM-2007/230, Oak Ridge National Laboratory, February. (Draft)

Jones, Willie D., 2005, “Take This Car and Plug It”, IEEE Spectrum, July 2005.

<http://ieeexplore.ieee.org/ie15/6/31432/01460339.pdf?arnumber=1460339>

Kintner-Meyer, M., K. Schneider, K., and R.Pratt, R. (2007)., Impact assessment of plug-in hybrid vehicles on electric utilities and regional U.S. power grids. Part 1: technical analysis., 
Pacific Northwest National Laboratory,. Richland, WA, <http://www.pnl.gov/energy/eed/etd/pdfs/phev_feasibility_analysis_combined.pdf>

Kiplinger 2006, Annual Auto Sales, 1985-Present Internet site accessed 9/11/2006. <http://www.kiplingerforecasts.com/economic_outlook/tables/autos/autos_annual.htm>

Kliesch, J. and T. Langer 2006, Plug-In Hybrids: An Environmental and Economic Performance Outlook, Report \#T061, American Council for an Energy-Efficient Economy, Washington, DC, September. $\langle$ http://aceee.org/pubs/t061.pdf?CFID=3423510\&CFTOKEN=77604544>

Markel, T., A. Brooker, J. Godner, M. O'Keefe, A. Simpson and M. Thornton, 2006, Plug-In Hybrid Vehicle Analysis, NREL/MP-540-40609, National Renewable Energy Laboratory, November. < http://www.nrel.gov/docs/fy07osti/40609.pdf >

Ostroff, Jim 2007, "Is a Hybrid in Your Future? More Say Yes!", Kiplinger Business Resource Center, Kiplinger.com internet site accessed 12/4/2007.

$<$ http://www.kiplinger.com/businessresource/forecast/archive/More Hybrids in the Future 072 007.html>

Parks, K., P. Denholm, and T. Markel, 2007, Costs and Emissions Associated with Plug-In Hybrid Vehicle Charging in the Xcel Energy Colorado Service Territory, NREL/TP-640-41410, National Renewable Energy Laboratory, May. < http://www.nrel.gov/docs/fy07osti/41410.pdf>

Santini, Danilo J., 2006, Statement to the U.S. Congress House Committee on Science Energy Subcommittee. Hearing on Plug-in Hybrid Electric Vehicles, May 17. <http://gop.science.house.gov/hearings/energy06/May 17/Santini.pdf >

Simpson, A., 2006, Cost-Benefit Analysis of Plug-In Hybrid Electric Vehicle Technology, NREL/CP-540-40485, National Renewable Energy Laboratory, November.

<http://www.nrel.gov/docs/fy07osti/40485.pdf >

Uhrig, Robert E. 2006, "Greenhouse Gas Emissions from Gasoline, Hybrid-Electric, and Hydrogen Fueled Vehicles", EIC Climate Change Technology, Institute of Electrical and Electronics Engineers, May.

<http://ieeexplore.ieee.org/xpl/RecentCon.jsp?punumber=4057290> 